

\section{THE UNIVERSITY}

\section{OF ILLINOIS}

$$
\begin{gathered}
\text { LIBRARY } \\
572 \\
F 4539 \\
\text { no.22-31 }
\end{gathered}
$$

UHUETERADUATE LHORARY ROOA 101 
The person charging this material is responsible for its return to the library from which it was withdrawn on or before the Latest Date stamped below.

Theft, mutilation, and underlining of books are reasons for disciplinary action and may result in dismissal from the University.

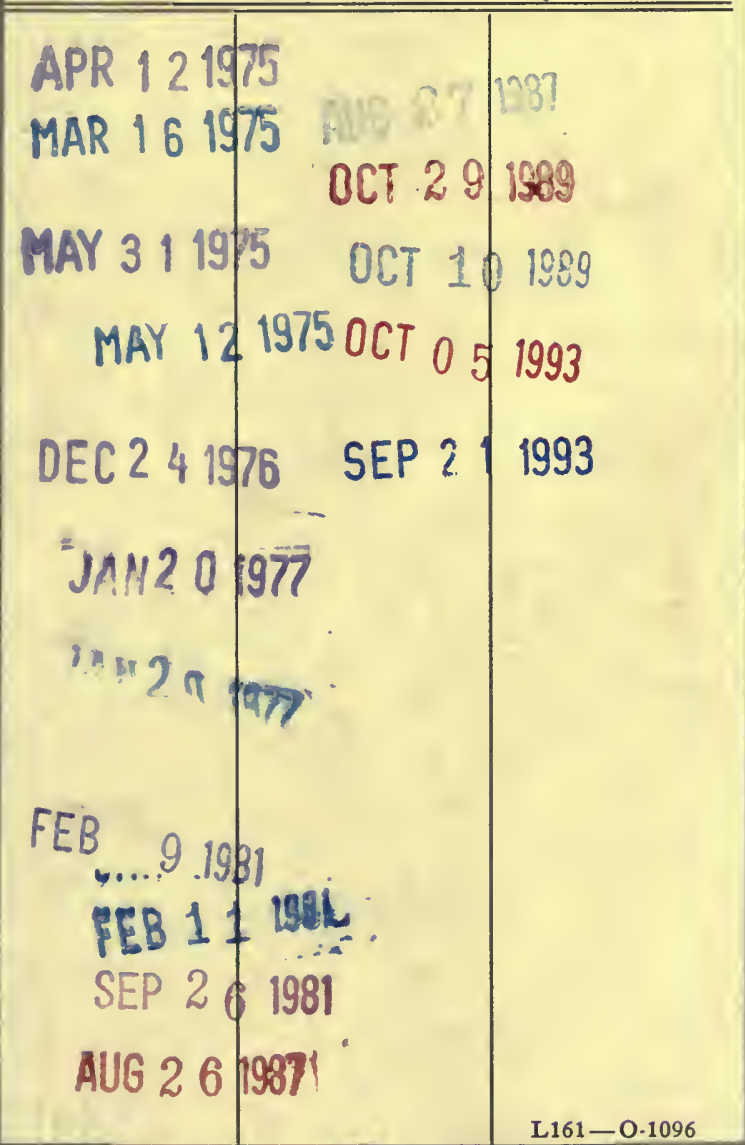






\title{
The Civilization of the Mayas
}

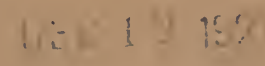

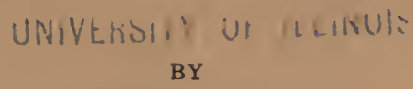

J. ERIC THOMPSON

Assistant Curator of Mexican and South American Archaeology

1 Map, 12 Text-figures, 14 Plates

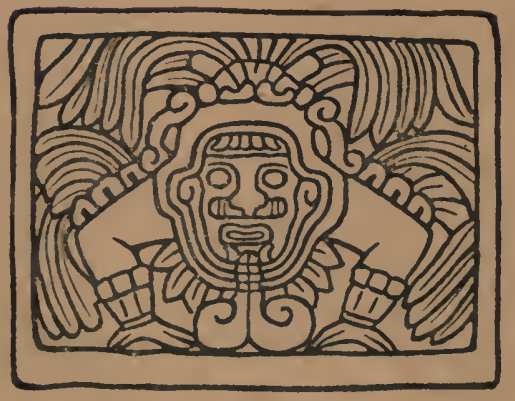

ANTHROPOLOGY

LEAFLET 25

FIELD MUSEUM OF NATURAL HISTORY CHICAGO 
The Anthropological Leaflets of Field Museum are designed to give brief, non-technical accounts of some of the more interesting beliefs, habits and customs of the races whose life is illustrated in the Museum's exhibits.

\section{LIST OF ANTHROPOLOGICAL LEAFLETS ISSUED TO DATE}

1. The Chinese Gateway . . . . . . . . . \$ .10

2. The Philippine Forge Group : . . . . . . . $\quad .10$

3. The Japanese Collections . . . . . . . . . $\quad .25$

4. New Guinea Masks . . . . . . . . . . . .25

5. The Thunder Ceremony of the Pawnee . . . . $\quad 25$

6. The Sacrifice to the Morning Star by the

Skidi Pawnee ... . . . . . 10

7. Purification of the Sacred Bundles, a Ceremony of the Pawnee . . . . . . . . . . . 10

8. Annual Ceremony of the Pawnee Medicine Men : .10

9. The Use of Sago in New Guinea . . . . . . . $\quad .10$

10. Use of Human Skulls and Bones in Tibet . . . . $\quad .10$

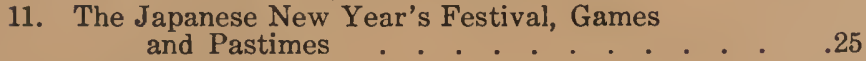

12. Japanese Costume . . . . . . . . . . . . . . . $\quad .25$

13. Gods and Heroes of Japan . . . . . . . . . $\quad .25$

14. Japanese Temples and Houses . . . . . . . $\quad .25$

15. Use of Tobacco among North American Indians - .25

16. Use of Tobacco in Mexico and South America . . $\quad .25$

17. Use of Tobacco in New Guinea . . . . . . . $\quad .10$

18. Tobacco and Its Use in Asia . . . . . . . . . $\quad .25$

19. Introduction of Tobacco into Europe . . . . . .25

20. The Japanese Sword and Its Decoration . . . . $\quad .25$

21. Ivory in China . . . . . . . . . 75

22. Insect-Musicians and Cricket Champions of China . $\quad .50$

23. Ostrich Egg-shell Cups of Mesopotamia and the Ostrich in Ancient and Modern Times . . . $\quad .50$

24. The Indian Tribes of the Chicago Region with Special Reference to the Illinois and the Potawatomi . . . . . . . . 25

25. Civilization of the Mayas : . . . . . . . $\quad .75$

26. Early History of Man . . . . . . . . . . . 25

D. C. DAVIES, DIREctor

FIELD MUSEUM OF NATURAL HISTORY

CHICAGo, U. S. A. 
THE IARAH?

Of 1 H

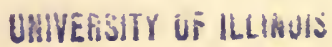




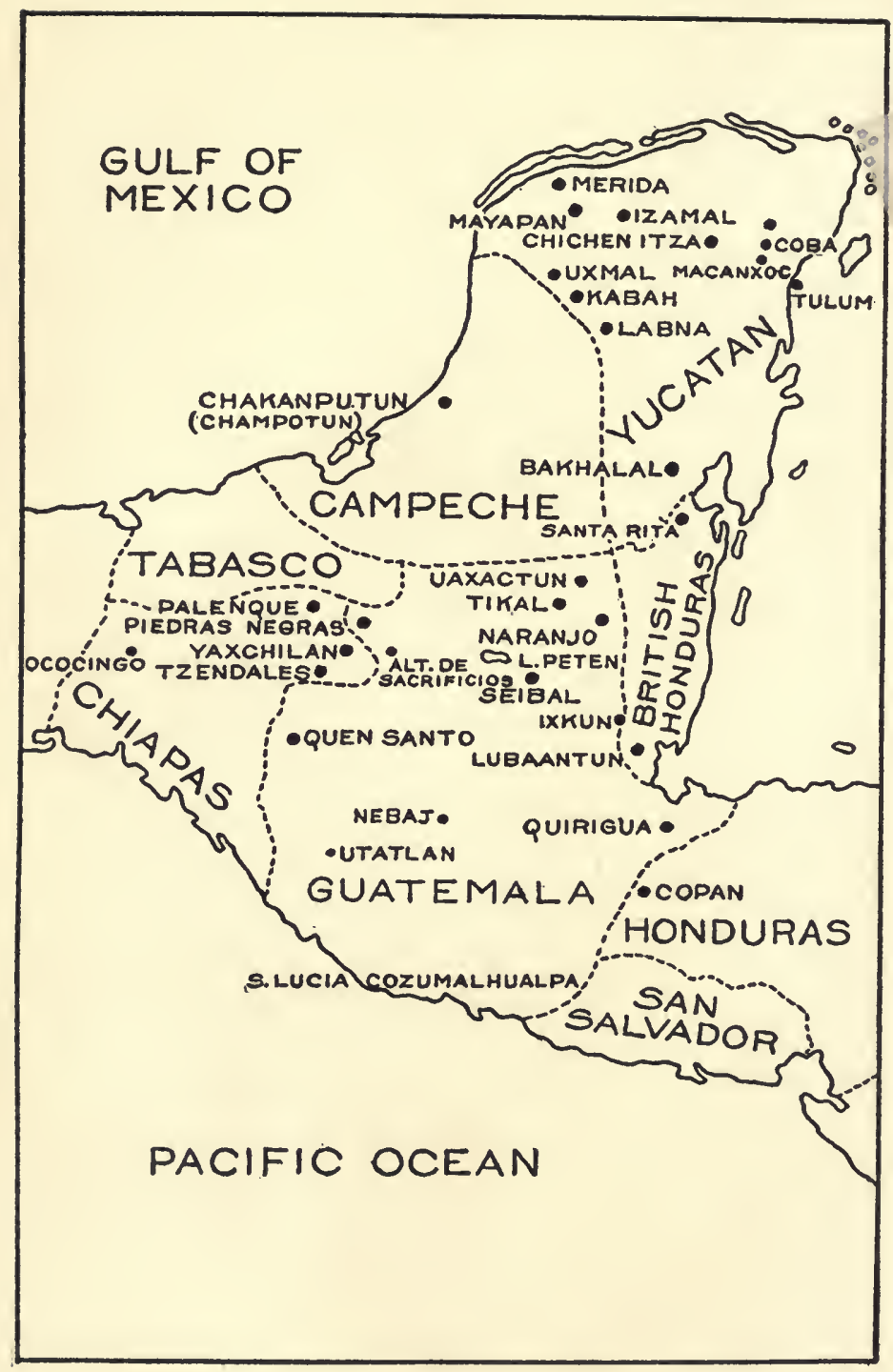

Map.

The Maya Area with Principal Cities. 


\section{DEC 191927}

\section{UNIVERSAY Un hanUIS}

Field Museum of Natural History

DEPARTMENT OF ANTHROPOLOGY

Chicago, 1927

\section{Civilization of the Mayas}

\section{CONTENTS}

The Dawn....................... 2

An Outline of Maya History ............. 9

Religion...................... 23

Quiche Legends................... 39

The Calendar. . . . . . . . . . . . . . . . 46

Religious Ceremonies and Human Sacrifice....... 60 -

Social Life...................... 71

Warfare, Art, and Architecture ............ 84

The Maya Collection of Field Museum........ 94

Chronological Table of Maya History . . . . . . . . 102

Bibliographical References................ 103

Index....................... 105 


\section{THE DAWN}

Some day, perhaps, a great artist will paint the discovery of America with historical exactness. Many pictures exist of that event representing Christopher Columbus standing on the prow of the Santa Maria gazing at the new continent. Columbus, however, only discovered America for the inhabitants of the Old World. The painting we hope to see some day will depict the discovery of the New World for the first time. It will be a hard subject: the artist will have to draw on his imagination to portray the features, clothes, and weapons of the first aborigines. We do not even know how, or where, or when they arrived. Probably toward the middle of Quaternary times; perhaps fifteen thousand years ago, man first trod on American soil. In all likelihood there existed then a land bridge connecting northern Asia with America. We can only guess at the habits of the first invaders of this continent by comparing them with their fellowmen who lived at the same period in western Europe,- - a very hazardous experiment, as the mere fact that two peoples are contemporaneous does not imply that they are on the same cultural level. However, in all probability, there was a general resemblance between Upper Palæolithic man of western Europe and the invader of America, and so he may serve as our type. He lived either out in the open or in the entrances of caves, dressed in the skins of the animals he slew with his stone or bone pointed spear. He employed flint for his weapons, and had not yet learnt to polish hard stone, but made points and harpoons of reindeer bone. He was an artist, too, and showed considerable skill in carving and painting the animals he hunted. He had no pottery, agriculture, or domestic animals, and depended entirely on hunting for his food; to procure a good bag he almost certainly 
practised magic which would bring in its train a regular guild of sorcerers.

Probably the first immigrants drifted across in small bands travelling southward slowly, and populating in the course of thousands of years the whole American continent. Their remains found in caves in Brazil and Chile demonstrate that they had exceedingly long heads, low retreating foreheads, and beetling brows. Broad-headed people followed them in sufficient numbers to swamp the predecessors. Later arrivals may have brought with them new arts and crafts, new religious conceptions, and new forms of social organization. The chief cultivated food plants of America, such as maize, squashes, potatoes, etc., are natives of Mexico or South America. The complete absence of the leading Old World food plants in America, on the other hand, shows that the immigrants did not bring seed with them. An agricultural people is very seldom nomadic, but if a migration takes place, the husbandman will not leave for a new land without the one necessity for existence, namely seed. These later immigrants may have crossed from Siberia to America in boats, as the land bridge possibly disappeared about the same time as England became an island. Immigration across the Atlantic can be ruled out as extremely unlikely. There remains the Pacific. The question of possible arrivals from the islands of the Pacific is debatable, and although small numbers may have reached America in this way in comparatively late times, introducing some new customs, early immigration on a large scale from this quarter can be fairly safely rejected.

We are still very much in the dark as regards the history of America in the hundred to hundred and fifty centuries preceding our era. Occasional archæological discoveries enable a feeble ray of light to be flashed on the fringes of this impenetrability, but the past is, to 
change the metaphor, like some distant landscape,two or three objects, detaching themselves from their surroundings, stand out prominently, but the rest of the picture is lost in the haze of distance. There are no vast accumulations of deposits left in layers in caves by the original inhabitants, such as occur in western Europe, and allow us to follow the stages of development step by step from the times of the last glaciation to the age of copper and bronze. The American Indian, it appears, was never greatly addicted to caves or rock shelters, the habitation of which, in the Old World, owing to their scarcity, is often continuous, but preferred open land on which to camp. As any dry land near water was suitable, a continuous occupation of any one site is extremely unlikely in the absence of agriculture.

The stage of agriculture means a fundamental change in the welfare and status of man. The acquisition of the plough, or the digging stick in the case of America, enables a nomadic people to become a settled community. The eternal pre-occupation of whence the next meal is to come gives place to a sense of security accompanied by leisure which in many cases may mean time for invention. A larger population can be maintained, bringing in its train specialization,-a further incentive to invention.

The relatively dense agricultural population supplies us with what we could not find in the hunting communities of America-stratigraphy.

A long series of excavations made in the Valley of Mexico City during the course of the last fifteen years has shown a clear case of superposition of one culture on another. Pottery objects occur from the surface to a depth which in some cases in as much as thirty feet below the surface. The excavations at Azcapotzalco may be taken as typical of those made throughout the area. 
Azcapotzcalco is a town at present of little importance, but formerly it was one of the three great cities of the Mexican Valley. It lies a few miles northwest of the city of Mexico, and at one time was close to the slopes of Lake Texcoco ; but owing to the shrinkage of the water, it is now at a considerable distance from the lake. It was the capital of the Tecpanec, a nomadic tribe akin to, though preceding by centuries, the better known Aztecs, who were very late immigrants into the Mexican Valley and who on their arrival were of such little importance that they were only too pleased to have the protection of the ruler of Azcapotzalco.

Excavations have revealed some twenty-five feet of culture-bearing strata. Near the surface exist pieces of pottery, implements and utensils, and little pottery gods known as figurines of Aztec type. Below this is found a layer, some six or seven feet thick, of similar objects of a type akin to those found in the ruins of Teotihuacan and which from traditions we believe to date from about the seventh century A.D. Underneath, for a depth of nearly eighteen feet, there is a layer which contains remains of the "Archaic" civilization, as it is called.

Attempts to date the lowest levels of this deposit by calculating the rate of accumulations for each century have been made, but at the best this is a very rough and ready and hardly reliable method. However, similar objects have been found in burials on the outskirts of Mexico City beneath a cap of lava, which on geological grounds is believed to have been deposited by an eruption that occurred about 1000 B.C. at the latest. Thus it may be stated with some certainty that this "Archaic" civilization is at least three thousand years old.

Pottery is found in this layer, usually of a rather simple character. The decoration is usually of faces in 
relief. Paint is sometimes used for simple geometric designs, which show obvious signs of having been derived from textile designs; weaving therefore may be added to the accomplishment of the Archaics. The pottery vessels are often supplied with three feet, sometimes plain, sometimes modelled as faces or feet, and usually hollow with a slit running down the inside. Pottery figurines are very common (Fig. 1). They are coarsely made: usually the head alone occurs, poorly shaped with protruding eyes and lips made by adding lumps of clay; the head-dress often takes the form of a double-banded turban. Paint is of common occurrence. Full figures of men or women occur, in many cases nude, in others showing signs of tattoo, ear-rings and nose-rings. The extremities of the limbs are usually out of proportion and poorly modelled. Stone statuettes showing the same art occur, but they are more usual in southern Mexico. Sometimes the pottery figurines are standing, at other times sitting. They are represented with weapons, playing on drums, or, in the case of women, nursing their children. Perhaps many of them were meant to represent the dead, as they are often found in graves.

The Archaic civilization is found over an area extending from north-west Mexico to Ecuador, Colombia, and Venezuela. The worship of the serpent which played such an important part in the religion of the Mayas seems to have been of very little importance among the Archaics, although serpent designs on Archaic pottery are occasionally met with.

The steps by which the Archaic civilization gradually evolved into the culture which with Maya influence was to form the basis of the civilization of the Plateau can be traced with some certainty at Azcapotzalco, or any of the other sites of excavations, but this is another story, outside the scope of this book. The effect of the Archaic civilization on the development 

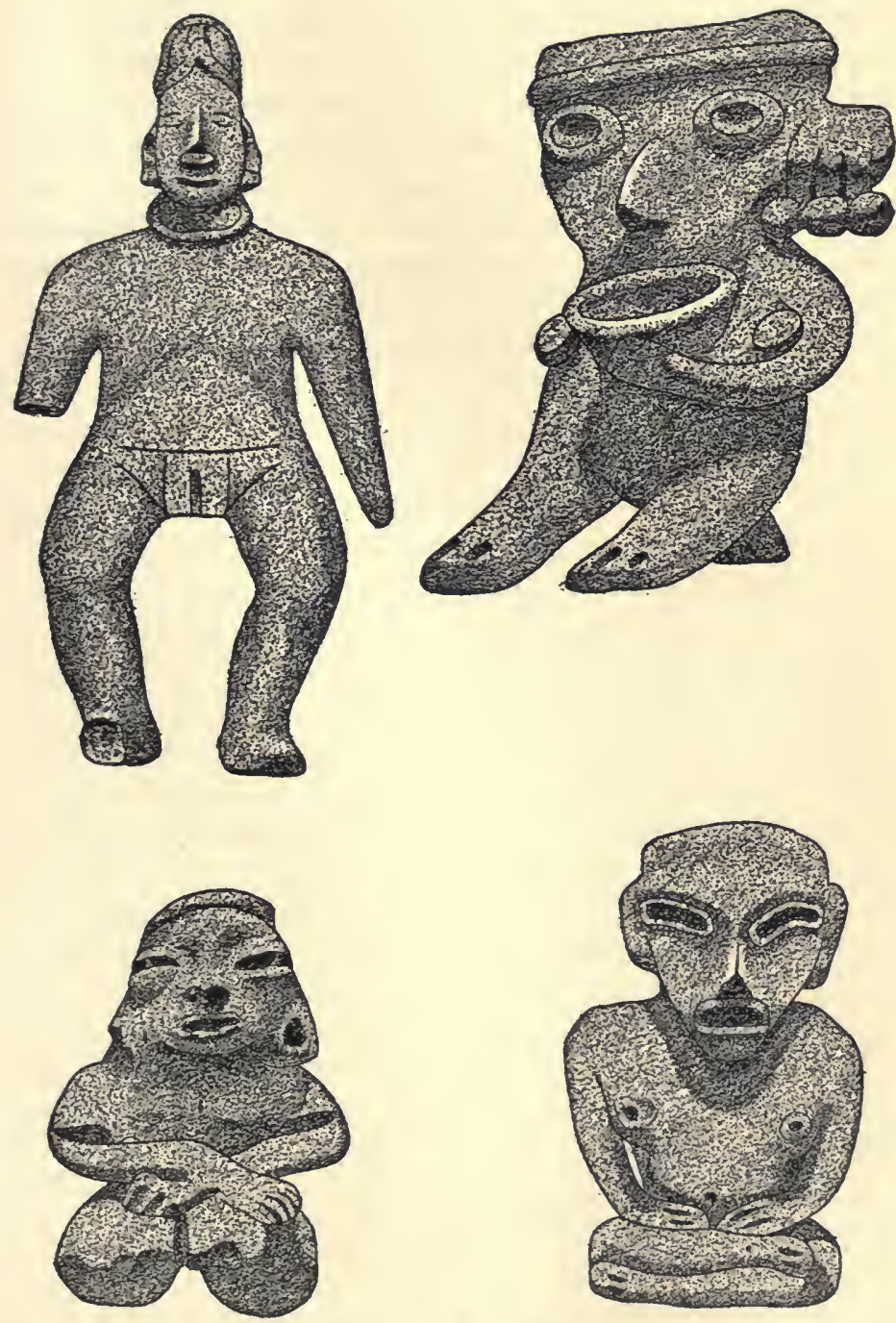

Fig. 1.

Archaic Figurines.

In Field Museum. 
of Maya culture is a difficult subject. It was no doubt very great, and further excavation may supply us with the links that will definitely show how the former was the basis on which the latter was built; but for the present we must take a leap from the Archaic to the early Maya, conjecturing that the Maya culture was evolved to a large extent from a localized development of the Archaic and then, moving out from its birthplace, was re-engrafted in Central America onto the same Archaic stock from which a branch of it had evolved. 


\section{AN OUTLINE OF MAYA HISTORY}

When Cortez and his band of pillaging adventurers swept through Mexico and Central America with flaming torch in one hand and the cross in the other, Copan and the other great Maya cities of the Old Empire remained unmoved. Centuries before the great Aztec Empire was humbled to the dust, and the proud Montezuma lay a prisoner in the hands of the Spaniards, the Mayas had abandoned the great cities they had raised stone by stone, and had surrendered to the ever encroaching forest the broad acres of maize that surrounded them.

The original home of the Mayas is still a matter for conjecture, but there is some reason for believing that they hailed from the district around Vera Cruz. To this day there live around Vera Cruz and extending northward as far as the Panuco, two tribes, the Totonac and, to the north of them, the Huaxtec, who speak a dialect of the Maya tongue and whose culture bears a strong resemblance to that of the Mayas. Although the earliest Maya cities are situated at a great distance from the Vera Cruz district, it is interesting to note that the earliest dated object of Maya workmanship as yet discovered was found on the route that would have been followed by migrants travelling from the Vera Cruz district to Uaxactun, in northern Guatemala, the earliest known Maya city. This date is inscribed on a little jadeite statuette found at San Andres Tuxtla in the province of Vera Cruz, and is some hundred and sixty years earlier than the first date at Uaxactun, about A.D. 160, whereas the Uaxactun date is about A.D. 320. The Goodman correlation is followed in this book. Those who are convinced by Morley's arguments have only to make the dates in every case 260 years earlier. It would indeed be a coincidence that 
the earliest Maya should also be the only dated object that has been found outside the Maya area. We can reasonably conjecture that the main branch of the Mayas migrated toward Central America, leaving behind the Huaxtec, who may have been on a slightly lower cultural level than their kindred migrants. Their astronomical skill and highly complicated calendar could not have been evolved during their journeyings. Hence we may assume that these were acquired before the pilgrimage began. Possibly they had been separated from their Huaxtec kin for a considerable period before their journey eastward. Uaxactun was discovered in 1916 by an expedition of the Carnegie Institution. It is in the Peten district of Guatemala, some fifteen miles north-west of Tikal, another early Maya settlement, and some three hundred and fifty miles south-east of San Andres Tuxtla.

Although no other city has revealed up to the present any date so early as that of Uaxactun, this does not necessarily mean that this city is the oldest. There is every reason to assume that many early dates were carved in wood which after so many centuries of exposure has rotted away. However, some good woodcarving, now in the British Museum, and in Basle Museum has been preserved from Yaxchilan (Menché). The large number of uncarved stelæ suggest also that in early times dates were painted on the stelæ, instead of being carved. We know that the stelæ were often, if not invariably, painted, although in most cases no traces of paint now remain. During the centuries of abandonment, nature has fulfilled her mission of destruction and disintegration only too well.

The chief early Maya cities, all dating from the first quarter of the ninth cycle (A.D. 436-534) are Tikal, Palenque, Copan. The last by far was of the greatest importance. It is impossible to say whether the old Maya Empire was divided into a number of 
city states as was ancient Greece. If that were the case, Copan was certainly the Athens of Central America. By the magnificence and number of her buildings and sculptures she far outstripped the other cities, and in addition she seems to have been the great astronomical and possibly the sacred centre of the Old Empire. A number of sculptured altars seem to portray a great astronomical or sacred conference. A series of figures, richly garbed, are seated facing toward a sculptured date which from its repeated occurrence must have been of considerable importance.

The great hieroglyphic stairway at Copan, unfortunately to a large extent destroyed, was unsurpassed for magnificence. The city at its greatest period, towards the close of the ninth cycle, must have been an imposing centre, of unsurpassed grandeur, with its great temple-topped mounds and clusters of courts, its innumerable carved stelæ, and its great walls sweeping down to the river. Even at present, where all is ruin and destruction and the vandal hands from the village near-by complete the destruction wrought by the engulfing forest with its giant-rooted trees that tear great gaping wounds in the monuments, Copan retains its by-gone splendor. In the second and third quarters of the ninth cycle (A.D. 534-731), large numbers of new cities arose,-Piedras Negras, Naranjo, Yaxchilan, and Quirigua, to name only the most important. Quirigua was in all probability a colony from Copan, and in the artistic beauty of its stelæ surpassed even the mother city. It will be noticed by a reference to the map that whereas the earliest cities were far apart, Palenque and Copan forming the feet of a triangle that had its apex in the cities of Uaxactun and Tikal, the newer cities were for the most part built within this triangle. As a rule one expects expansion from the centre outward, but the Mayas worked inward. 
A period of unexampled prosperity intervened. City after city arose, and the population must have been very dense. The dwelling houses, which were made of wood, thatch, and adobe, have crumbled into ruins, leaving no trace behind, but the close proximity of the cities with their innumerable artificial mounds, palaces, and temples must have demanded the labor of a huge population for their erection.

War scenes are almost entirely absent from the sculpture of the south-eastern cities. There are, however, a few scenes that may represent prisoners being brought in captive, and one or two armed warriors are found sculptured on the monuments of the northwestern area. We may safely conclude, however, that the Mayas were living in peace among themselves and that war was confined to the repulsion of invading hordes descending from Mexico. Militarism or civil war would have put an effectual stop to the building operations and artistry that characterize the great period of the Old Empire. The marked resemblance in the motifs and designs of the sculptures throughout the area at this period point to very extensive intercourse, even fashions in clothes and headgear seem to have been widely diffused.

Just as Athens was crushed at the very height of her power, so the Maya Empire was destined to fall within a century of her greatest period. In the closing bi-decade of the ninth cycle, one by one these proud cities were abandoned. One or two, such as Tikal, lingered on into the beginning of the tenth cycle, but by A.D. 870 the last city of the Old Empire had been deserted, and the Mayas had set off on their wanderings.

Many theories have been brought forward to account for this exodus. (The view has been advanced that the Mayas were forced to evacuate territory owing to pressure from Mexican invaders. Although we 
know that great racial movements were taking place about this time on the highlands of Mexico, which must have made themselves felt over large areas, it is very doubtful that this was indeed the main reason. If the Mayas abandoned their territory in face of the invaders from the north, it would be only natural to expect that the cities, instead of becoming deserted, would merely have changed their ownership, but such is not the case.

It has been suggested that wasteful methods of agriculture made conditions harder and harder for the Mayas in the old cities and that eventually city after city had to be abandoned owing to the exhaustion of the surrounding soil. This would have resulted in an annual decline of production, which continued until famine stared the inhabitants of city after city in the face. The Maya system of agriculture was primitive, and still is so among the present Mayas.

Land suitable for agriculture was prepared by burning off the trees and undergrowth. After the rains, the sower, armed with a bag of seed and a sharp-pointed stick, crossed and recrossed the field, making a hole with his stick in the ground at every pace, and throwing a few grains of maize into the pit. Maize was the staple food of civilized America, and in the absence of Old World cereals, no good rotation of crops was possible. Maize, even with good preparation of the soil made possible by deep ploughing and long harrowing, can be sown only two or three years consecutively on the same land. At the end of this period the field was abandoned, and the Maya farmer marked out a new piece of land to be cleared and sown. In the course of time and with the large increase of population that undoubtedly occurred, the Mayas must have been driven farther and farther afield in search of virgin soil. The exhausted soils nearer home must have been resown after shorter and shorter periods of 
recuperation. In time the yield of the district would have fallen below the level of consumption, and faced with the alternative of evacuation or starvation, the people chose the former. Whether this suggestion is correct or not, it is impossible to say, but it is the most plausible yet advanced.

Possibly too the fact that a thick turf tends to replace the forest growths after several consecutive clearings may have been an important factor in the process of exhaustion. Where such thick sward had taken root the Mayas with their primitive agricultural methods were unable to plant their crops. Whatever the causes, there can be no doubt that the parting must have been a bitter one. It can have been no light sacrifice to abandon the magnificent cities that commemorated the labor and devotion of centuries, and to sally forth into the unknown to start afresh. Israel in captivity, weeping over Jerusalem, had less to mourn than the Maya exile; for the Jews, although far from their homeland, had at least the consolation of living in civilized surroundings of greater magnificence than Jerusalem. Whereas the Maya was set down in a new inhospitable land, bare of all the luxuries and beauty to which he had been accustomed in his old home. One branch of the Mayas travelled toward the south-west, settling at Quen Santo, on the outskirts of the Sierra Madre Mountains, where the present states of Guatemala and Mexico meet, but the vast majority of the peoples of the Old Empire turned northward, advancing into northern Yucatan by way of the east coast.

This great break in the Maya civilization also synchronizes with the advent of a new source of information. The Maya scholar, who has hitherto been forced to depend for all his information on what can be gleaned from the monuments, has now at his disposal the traditions and chronicles of several of the ruling 
families of the New Empire, which, though differing on some points, are on the whole in fairly close agreement. They help to bridge a gap in a period of which otherwise we should be woefully ignorant.

These accounts, which were originally in hieroglyphs, were luckily reduced to writing in the sixteenth century before their interpretation was forgotten. They are written in the Zuyua (Maya) language, but Latin script is employed. A rough outline of Maya history is given from the time Mayas settled in Yucatan until after the Spanish conquest, which enables us to correlate with accuracy to within a year the Maya dates with those of our era. A list of the Katuns (periods of twenty years) are given that stretch over a period of some eight hundred years, and their general accuracy is confirmed by archæological data.

The first settlement of Yucatan took place as early as the third quarter of cycle 9, before the Old Empire cities of Copan, Naranjo, etc., had reached the height of their power. This settlement seems to have taken the form of a gradual infiltration of northern Yucatan by way of the east coast of the peninsula. Tulum, an important site on the east coast, had been settled by A.D. 700. Inland, in a line running roughly west from there, Cobá and Chichén Itzá had also been founded.

The geological conditions of Yucatan are very different from those obtaining in the area of the Old Empire, which is covered by a close network of water courses and streams. Yucatan is entirely destitute of running water and, were it not for a number of natural wells known as cenotes, would be uninhabitable, as most of the peninsula is a vast limestone plain through which the rain rapidly percolates. Breaches in the limestone occur at a number of places, forming these cenotes, and at Chichén Itzá there were at least two very large ones that made it an ideal spot for settle- 
ment. The name Chichén Itzá, in fact, means "mouth of the wells of the Itzá" in Zuyua (Maya).

The Itzá were the Maya tribe who first settled at this spot. Their settlement lasted two hundred and twenty years. They then abandoned the city and moved across to Champotun (Chakanputun) on the west coast, where they lived in peace a period of two hundred and sixty years. About twenty years after the Itzá had settled at Champotun, another tribe known as the Xiu moved into Yucatan and settled at Bakhalal on the east coast of Yucatan. After sixty years' residence at this spot they moved to Chichén Itzá, which had remained unoccupied since its abandonment by the Itzá. Here they remained a further hundred years until, as the native accounts cryptically state, "Chichén Itzá was destroyed." The Xius then proceeded to Champotun, where, attacking the Itzá, they drove them out of the city and settled there themselves. The Itzá wandered forty years in the wilderness, suffering great hardship. "The Itzá wandered, sleeping in the woods' amid the rocks and wild vegetation, suffering great privations," to quote from their chronicles. In the preconquest historical codices, now unfortunately lost, one imagines these scenes were painted with great vividness, but in the script this is all condensed into one tense sentence.

At last, about the year A.D. 1250, Chichén Itzá was reoccupied. The Maya dark ages were over, the renaissance was at hand. These perpetual shiftings that had lasted close on four hundred years had had a drastic effect on Maya civilization: the art which had been the glory of the Old Empire had suffered a blow from which it never recovered; the sculptures of Yucatan never reached the high level attained in the ninth cycle, and stucco work in many cases took the place of stone engravings. Architecture, on the other hand, received an impetus, once settled conditions ob- 
tained, that led to a great development and the construction of edifices which for size and decoration were far superior to those of the earlier civilization. Façade work became very prominent, and although naturalistic work is not very frequent, some very pleasing geometrical designs were evolved.

Shortly after the resettlement of Chichén Itzá an alliance was concluded between the Itzá and the rulers of Mayapan and Uxmal, both Maya cities. Mayapan, the great centre of the worship of Kuculcan, the feathered snake god, seems to have been the paramount partner in the triple alliance from the first. Chichén Itzá was the great religious centre of later times, and Uxmal held a position of ominous importance in the league.

The two following centuries during which the alliance endured form a period of great prosperity. The three city states between them dominated the whole of northern Yucatan, and were able, undoubtedly, to exert their influence on the whole Maya-speaking world, extending as it did almost to the shores of the Pacific. The chief cities waxed mighty, new colonies were established, and new temples and palaces arose on all sides. The New Empire had successfully passed the trials of the dark ages and bid fair to outstrip in power and magnificence its forerunner in Guatemala. The fates ordained otherwise: the monster of disruption, still so characteristic of these areas, raised its head. Civil war broke out, and progress received a fresh check.

The circumstances that led up to the destruction of the league are a little obscure. The different versions show evident signs of partisanship, but although they vary as to to whom the blame should be assigned, the story in brief is this.

Mayapan had become the dominant partner in the league. Her ruling family, the Cocomes, became 
somewhat harsh and domineering, and as a consequence the ruler of Chichén Itzá, a certain Chac Xib Chac, plotted against Hunnac Ceel, the head of the Cocom family. War ensued, and Mayapan with the help of Mexican mercenaries, drove out Chac Xib Chac.

Influences from Mexico had undoubtedly made themselves felt at Chichén Itzá considerably earlier than this first mention of them in the historical outline. There is reason to believe that Mexicans reached Chichén Itzá at the time the Itzá returned to their old capital and the league of Mayapan was established (about A.D. 1260). These Mexican invaders probably hailed from the area bounded by the modern states of Puebla and Vera Cruz, and were probably of Toltec affinities, both cultural and racial. They were instrumental in introducing a new religion, a new art, and possibly new methods of warfare. Apparently they established their rule at Chichén Itzá, and the profound influence they exerted can be seen to this day in the large number of beautiful palaces, temples, and colonnades they caused to be erected. Their religious life centered round the cult of Quetzalcoatl, the feathered serpent god, all-powerful divinity of the earth and sky, who was represented by a rattle-snake from whose body grew feathers and from whose mouth often protruded a human head. There seems reason to believe that this worship of the feathered serpent originated, possibly as an esoteric cult, among the Mayas themselves, and now as an exoteric and debased religion was re-introduced to them from Mexico.

The Nahua immigrants too seem to have been responsible for the introduction of human sacrifice, and to them was due the inception of the series of religious practices that centered round the great cenote or sacred well of Chichén Itzá. Sacrifices, both of humans and of precious objects of gold, jade, etc., were cast into the well as a propitiation of Chac, the 
all-powerful god of rain, and as an inducement to him to bless his dutiful worshippers with abundant rain at the right season. Should a victim cast into the well at dawn be still alive at mid-day, he was hauled up the fifty or sixty feet of precipitous cliffs that divided the surface of the pool from the brink of the great well, and was apparently raised to very high rank; for he was considered to have possessed divine power in order to be able to survive so long. The Mexican immigrants also introduced tlaxtli, a ball game (see p. 79), the use of colonnades, Atlantean figures, flat-roofed buildings, and, most important of all, the constant use of the feathered serpent as an ornamental motif. Practically every building at Chichén Itzá built after the second half of the thirteenth century has a decorative scheme in which the plumed serpent is the chief motif.

In some buildings the door portals are giant feathered serpents with their heads on the ground and tails in the air. In other cases the feathered serpents form the giant balustrades that guard the flanks of the stairways that lead up to the temples. On many structures too of this period the feathered serpent is carved in relief, usually upon the exterior walls.

Bishop Landa writes that an actual person, called Kuculcan, came from the West and became chief of Chichén Itzá, where he led an ascetic life, introducing the arts of writing and agriculture. He was also believed to have founded Mayapan, and after residing some time in Yucatan to have gone to Campeche, and there embarked for Mexico. Undoubtedly, there is a great deal of truth in this story of Kuculcan, but with our present knowledge of Maya history it is difficult to assign a particular period to his life. Possibly his arrival coincided with the return of the Itzá to Chichén Itzá, when there is reason to believe Mexican influence first made itself felt in Yucatan. 
The Mexican mercenaries, however, who helped Mayapan to defeat Chichén Itzá, were probably a fresh band of Nahua immigrants, who, though few in number, proved a decisive factor in the war owing to their use of the bow and arrow.

On the fall of Chichén Itzá, the Itzá moved south out of Yucatan to the shores of Lake Peten in Guatemala where they established themselves anew, not far from the original homes of their ancestors, who had lived in this district at the time of the first Empire. Here on the island of Tayasal in the middle of Lake Peten, the Itzá continued to flourish, and repulsing all attempts of the friars to christianize them, preserved their independence until the year 1697, a century and a half after their kinsmen of northern Yucatan had submitted to the yoke of Spain. Thus the Peten area of Guatemala that had first seen the light of Maya civilization grow to a steady flame, was to witness too its last feeble glimmer before it was extinguished for ever.

Mayapan won the first stage of the war, but, like Sparta after the overthrow of Athens, she was not long to enjoy her triumph in peace. Within a very few years the tyranny and exactions of Mayapan caused another outbreak of fighting. This time she lost the fight. Mayapan was overthrown, and the city was razed to the ground. The whole family of the Cocomes, with the solitary exception of one relative who was absent in another part of the country, was massacred. So ended the rule of Mayapan.

The fall of Mayapan meant the end of all centralized government. Every city and town became in all but name independent. Small puny leaders rose like mushrooms throughout the length and breadth of $\mathrm{Yu}$ catan, for ever fighting among themselves and ever pushing the country farther along the path that leads down to barbarism. In addition to the breaking down of all organized government, the country suffered a 
series of disasters that decimated the population and hurried on still more the approaching degradation. A great hurricane swept the country, hurling the trees to the ground and destroying whole towns. In many cases the houses that crashed to the ground were burnt, and the inhabitants entrapped beneath the wreckage roasted alive. The destruction must have been colossal, as the Spaniards reported that no big trees existed on their arrival, merely masses of young trees which had been planted in attempts at re-afforestation.

A few years later a disease attacked the crops and fruit just before harvest; famine ensued, and large numbers died from starvation. Next followed plague, which swept over the country, causing further depopulation, until, as Bishop Landa says, it was marvellous that even the small population that existed on the arrival of the Spaniards had survived.

These disasters, terrible as they were, were mere harbingers of worse to come. Slavery, massacre, foreign oppression, the destruction of their religion, the rape of their womenfolk awaited them at the hands of the Spaniards, - a sad end for the greatest civilization America had ever produced, but an end that was shared, too, by the other empires of the New World, the Aztec, Chibcha, and Inca. Their learning, art, and courage availed them little against the more modern weapons and armor of the Spaniard.

It is interesting to note that several prophecies of the arrival of the Spaniards have been recorded. One oracle announced that soon the country would be ruled over by a foreign race, who would preach one god and the wonderful virtue of a piece of wood. Possibly the Mayas had received information of the arrival and activities of the Spaniards in the West Indies. An older prophecy foretold that when huge deer (cattle ?) entered the country, the Maya religion would cease. 
The first Spaniards to land on Maya soil were a certain Geronimo de Aguilar and some twenty others, who in the year 1511 were wrecked, but managed to reach the coast of Yucatan, where a number were promptly sacrificed and their bodies eaten at a ceremonial feast. Aguilar and another Spaniard, Guerrero, escaped, while being fattened up, and falling into the hands of a friendly chief were saved.

It must have been a great source of satisfaction to the Mayas in after years in the midst of their tribulations to think that at any rate the first invaders had added glory to their gods.

The two survivors, Aguilar and Guerrero, were well treated. Aguilar, it appears, was a friar, and, according to his own account, lived a spotless and holy life, till he was rescued by Cortez some eight years later and proved of invaluable aid to the Conquistador as an interpreter. Guerrero rose to be military adviser to a chief living near Bakhalal, where he met with considerable success. He married a lady of rank, adopted Maya customs and dress, and apparently was so contented that he took no steps to rejoin his fellow countrymen when Cortez first arrived at Yucatan, and in fact he is believed to have led one of the Maya armies against the invaders.

The story of the conquest of Yucatan is outside the scope of this book. Suffice it to say that the Mayas put up a stout, though ineffectual resistance. The country was eventually subdued, and the land and people were parcelled out among the conquerors. Bishop Landa tells us that each Spaniard was granted two thousand Indian vassals, and the inquisition was introduced to prevent any relapses to the old religion. The natives driven desperate by their miseries committed suicide in droves, and thus were the benefits of European civilization bestowed upon the Mayas. 


\section{RELIGION}

The religious beliefs of the Mayas have reached us in a state of inextricable confusion, and the task of disentangling the threads is a matter of great difficulty. In every community, whether it be civilized or primitive, there always exist at least two different schools of religious thought which may be classified as being the view-points of the priest and of the layman. For the sacerdotal class religion is the vital purpose around which its life centres, whereas for the layman religion is a matter outside his every-day life. Not every priest is included in the sacerdotal class, and many laymen who possess the true religious complex should undoubtedly be placed in the first category. Although the two classes do tend to merge into each other to a certain extent, the extremes show a surprising difference, even in a community such as ours, where some fifteen centuries of stability and civilization have had an enormous influence in causing a tendency toward uniformity.

Among the Mayas this movement of convergence can never have existed. On the one side stood the priests who formed the educated class, on the other the uneducated masses. The difference between the speculative and esoteric doctrines of the former and the crude beliefs of the latter must have been very great. Unfortunately we have no means of ascertaining to which group such relics of the Maya religion as have reached us should be assigned. Our sources of information are various. Bishop Landa, to whom reference has already been made, is the only writer of conquest times who has given us any detailed account of the Mayas living in Yucatan at the time of the arrival of the Spaniards. 
Diego Landa was born in Spain of good family in the year 1524. At the age of seventeen he entered the famous monastery of San Juan de los Reyes in Toledo, joining the Franciscan order. He was one of the first Franciscans to go to Yucatan, where his zeal for the conversion of the Mayas was so great that he was mixed up in an illegal auto de fé and consequently recalled to Spain for trial. He was acquitted and returned to Yucatan in 1573 as second bishop of Merida. He has been described as a fanatic, but doubtless was no narrower than most of his contemporaries. Unfortunately his whole efforts were dedicated to the overthrow of the old religion, and he was responsible for the burning of great masses of Maya codices which were in his eyes works of the devil. Despite this terrible destruction, we owe him gratitude for his great book "Las Cosas de Yucatan" in which he describes at some length the customs and festivals of the Mayas.

Only three codices have survived the holocaust carried out by the Spaniards, and although still imperfectly understood, have added considerably to our. knowledge of the Maya deities.

A few references by other Spanish historians, notably Cogolludo, details gleaned from monuments, frescoes, and pottery complete our sources of information.

The great German Maya authority, Schellhas, has identified a number of gods in the three codices referred to above, to which he gives letters of the alphabet. A comparison of these gods with those found on the monuments and referred to by Landa and others enables us to add considerably to the information supplied by Schellhas. The letters given are those used by Schellhas for identification purposes. It must be understood, however, that there are still considerable differences of opinion as to the functions and attributes of the various deities. 
Far and away the most important gods were those intimately connected with agriculture and fertility, as is to be expected among a people such as the Mayas, whose whole existence depended on the size of the harvest. On the lowlands of Central America and the limestone areas of Yucatan, rainfall in abundance and at the opportune moment was of the utmost importance, and so not unnaturally the fertility of the gods is associated with thunder, lightning, and rain. Joyce has called attention to the very wide distribution in pre-Columbian times from Argentina to the United States of thunder and lightning gods represented with tears falling from their eyes, a good example of imitative magic. On the primitive principle that like produces like, the tears of the god will produce rain. The Mayas were no exception, and their god of rain (god B) was represented with streaming eyes, and his hieroglyph is a T-shaped figure which, as Joyce points out, undoubtedly represents an eye with tears falling from it.

God B (Fig. 2, Nos. 1-2 and Fig. 3, Nos. 1-2), the rain god, is invariably shown with a long pendulous nose with a curled object attached to the upper surface, which probably represents a rather conventionalized serpent's upper jaw. The snake is throughout the New World closely connected with rain. Possibly its sinuosity recalled the lightning which so often precedes rain in these latitudes, or the fact that snakes show themselves in large numbers immediately before and after a storm may have given rise to the connection. God B is sometimes shown with the body of a serpent, and more often sitting in or issuing from the jaws of a snake, and on two occasions with a snake in his hand. Although he has been identified as Kuculcan, the feathered serpent god, it seems more probable that he is Chac and that he is almost equivalent to Tlaloc, the rain god of Mexico. He is also found associated 


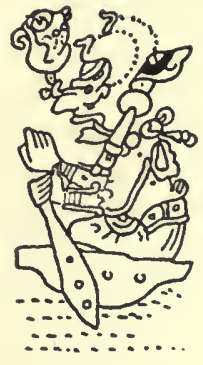

1

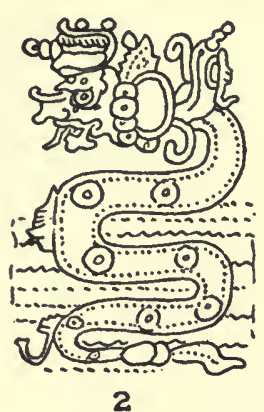

2

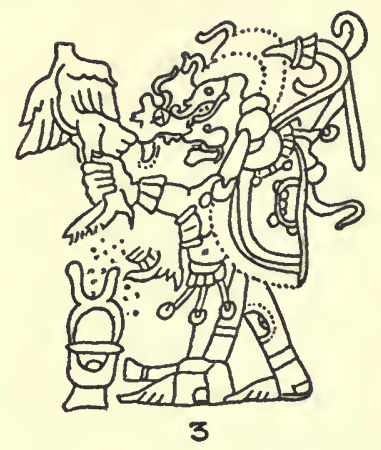

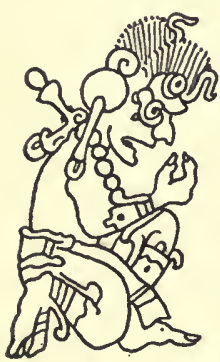

4

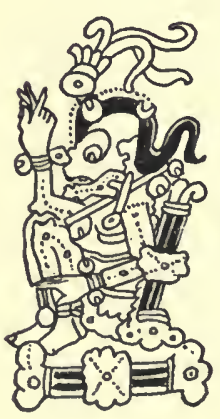

8

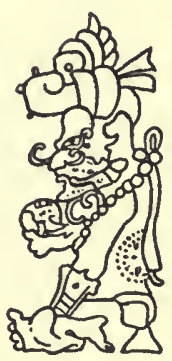

5

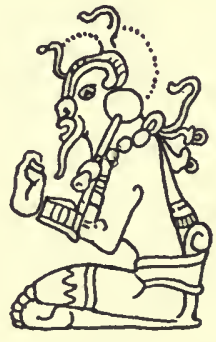

6

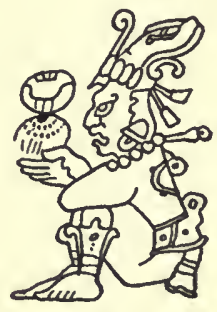

7

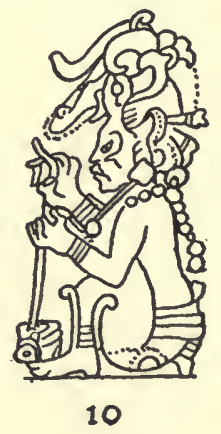

Fig. 2.

Maya Gods from the Dresden Codex.

$1-2, \operatorname{god} \mathrm{B} ; 3, \operatorname{god} \mathrm{K} ; 4, \operatorname{god} \mathrm{D} ; 5, \operatorname{god} \mathrm{G} ; 6, \operatorname{god} \mathrm{C}$;

$7, \operatorname{god} E ; 8, \operatorname{god} A ; 9, \operatorname{goddess}$ of suicides; $10, \operatorname{god} F$. 
with the symbols of the four directions which we are informed were represented by four subsidiary Chacs, as they were among the Nahua by four Tlalocs. The fact that god B is never shown with feathers on his body rules out any possibility that he is the feathered serpent. At all events, he was a god of primary importance, and is represented on the monuments of the Old and New Empires and in the manuscripts with more frequency than any other deity. He is essentially a benevolent deity in the codices, but on the monuments of the Old Empire he is sometimes depicted with a fleshless face and other symbols of death. Perhaps this is to express that rain is not always beneficial: sometimes too much rain falls and floods ensue, or the rain-soaked harvest rots.

Closely associated with god B is another god connected with fertility, god K (Fig. 2, No. 3), "the god with the foliated nose." On several occasions in the codices god B is shown carrying the head of god $\mathrm{K}$ either in his hand or on top of his own in the form of a mask. There seems to be little doubt that god $\mathrm{K}$ is the wind god. Förstemann suggests that the foliated nose represents the blast of the storm. Probably gods $\mathrm{B}$ and $\mathrm{K}$ are two manifestations of the original thunder god. God B, as we have seen, represents the rain and god $\mathrm{K}$ the wind that so frequently sweeps across the land before the downpour in the tropics.

The features of god $\mathrm{K}$ are slightly less anthropomorphic and resemble to a larger degree the conventionalized upper jaw of a serpent than in the case of god $\mathrm{B}$. The connection with thunder and lightning is even stronger.

The Maya and Nahua gods are closely related and a passing reference to the equivalent gods of Mexico will not be out of place.

Quetzalcoatl (which means "feathered serpent") as Eecatl, the wind god, who is said to sweep the path 

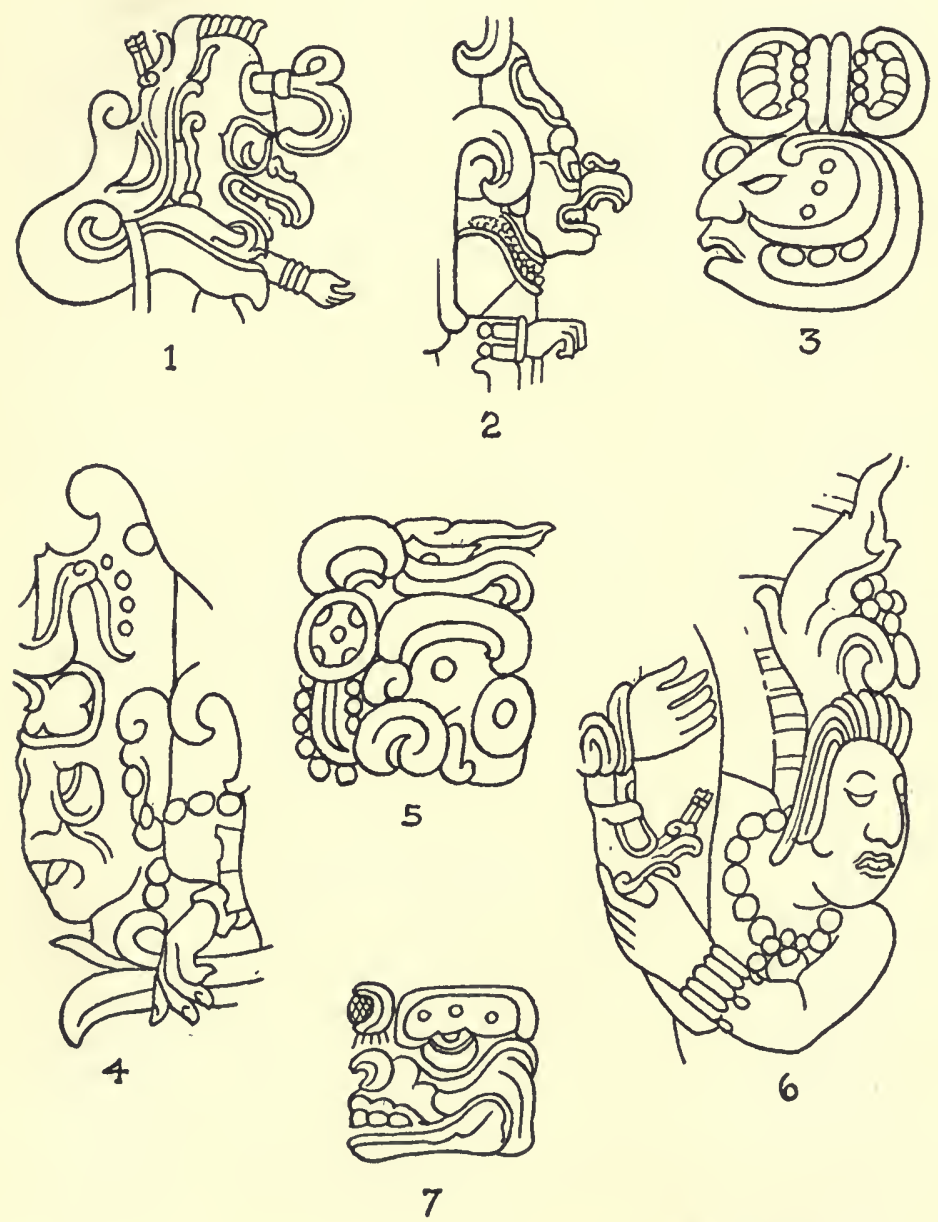

Fig. 3.

Maya Gods from the Monuments.

1-2, $\operatorname{god} \mathrm{B} ; 3, \operatorname{god} \mathrm{D} ; 4, \operatorname{god} \mathrm{G} ; 5, \operatorname{god} \mathrm{C} ; 6, \operatorname{god} \mathrm{E} ; 7, \operatorname{god} \mathrm{A}$. 
for the rain god, bears a resemblance to god $\mathrm{K}$. The same huge proboscis is his distinguishing mark. On his forehead he wears a small serpent, and in addition he carries a peculiar eye-mark which may be the tear referred to above.

Tlaloc, the rain god, is shown with a prominent conventionalized snake's jaw. On his forehead like Eecatl he wears a small serpent; and he, too, has a peculiar circle round his eye.

In all probability both these gods were borrowed by the peoples of the Mexican highlands from the Mayas, together with the feathered serpent, Kuculcan (Fig. 4). This deity had been of so holy a nature that he became the great mystery around which Maya life centred, and was thoroughly misunderstood by his Mexican borrowers. Unable to get to the root of the esoteric doctrines held by the priests concerning $\mathrm{Ku}-$ culcan, they adopted him as a god symbolic of the culture they had received from the Mayas, at the same time realizing that he was in some way connected with fertility. When Nahua immigrants settled in Yucatan in the thirteenth century, as described in the preceding chapter, they introduced with them this conception of the feathered serpent as a culture-hero god, which was incorporated into the Maya legends. Possibly Kuculcan was originally looked upon as the supreme god of the thunder and lightning, and gods B and $\mathrm{K}$ were manifestations of the two sides of his nature.

God D (Fig. 2, No. 4, and Fig. 3, No. 3), "the god with the Roman nose," is undoubtedly a sky god. $\mathrm{He}$ is said to have been the son of Hunabku, the creator, who like the creation gods of many primitive peoples was so far removed from man, and interfered so little in his affairs, that he could be, and was, safely ignored. Besides the prominent Roman nose, he is characterized by the features of an old man, a wrinkled 
face and a mouth that boasts but one tooth, and sometimes a beard. His head is also used as the glyph for the number 4, which suggests that as god of the sky his dominion extended over the four quarters of the globe.

Naturally as sky god, he ruled over night and day, and so we find him closely connected with both the moon and the sun. At other times he is depicted carrying the emblem of the moon.

It is generally agreed that he is Itzamna, and he is said to have been the introducer of writing and to have come from the East, but here again we may be dealing with a Mexican culture myth grafted on to Maya history.

The sun god so closely associated with Itzamna is god G, Kinich Ahau (Fig. 2, No. 3, and Fig. 3, No. 4). As far as we can gather, he did not take an excessively important place in the Maya pantheon. He was, however, the patron of the city of Itzamal which he was supposed to have visited daily at noon, descending as a macaw to consume the offerings made to him. He is usually represented with a peculiar scroll issuing from the end of his nose, and is as a rule shown with a beard which according to some authorities represents the rays of the sun. His lack of importance is probably due to the fact that his functions as a god of light are largely usurped by god D, Itzamna. As a fertility god he is overshadowed by the all-important trinity of snake gods.

One other god is associated with the heavens, god C (Fig. 2, No. 6, and Fig. 3, No. 5). Although he is depicted with great frequency in the manuscripts, and on the sculptures of the Old Empire, no reference has been made by Landa or other Spanish writers to a god that might conceivably be identified with him. Schellhas thinks that he is the deity of the polar star, and it is significant that his hieroglyph is also the sign 


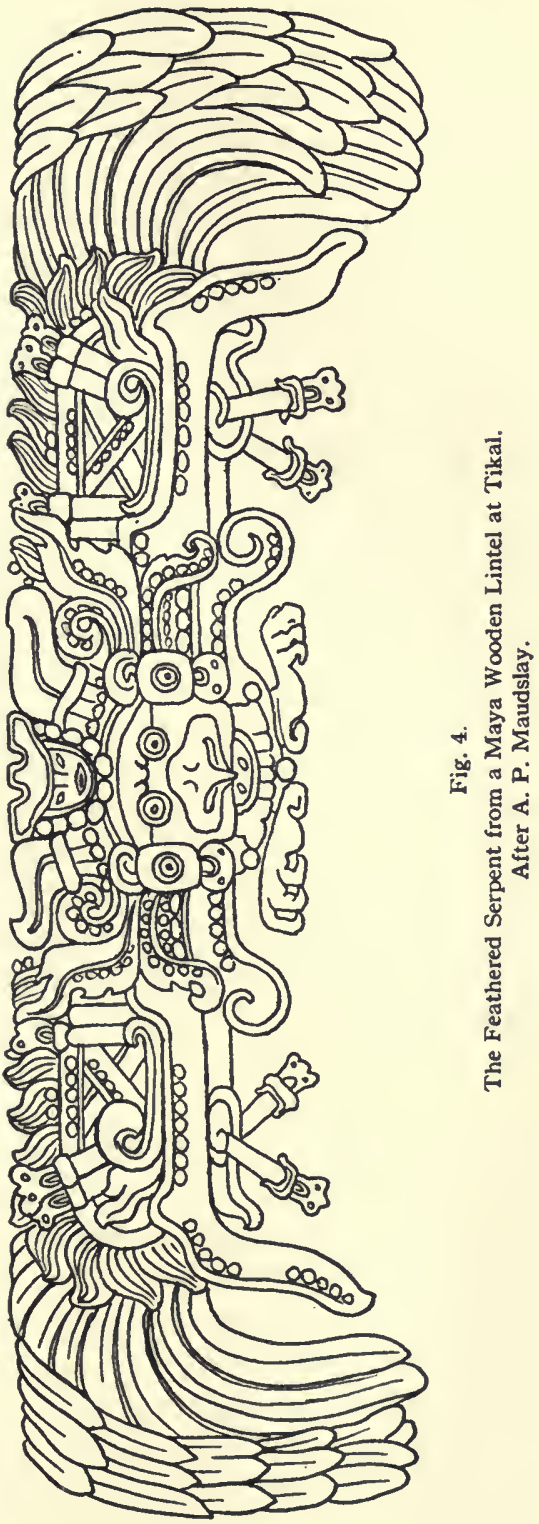


for the north. He is represented with the features of a monkey.

Maize, the staple product of the Mayas, was in the special keeping of a maize god, god E (Fig. 2, No. 7, and Fig. 3, No. 6), who is depicted with great frequency on the monuments of the Old Empire, as well as in the codices, though in the later stages of Maya history, his functions seem to have been taken over by the subsidiary Chacs. At the best he probably represented merely the spirit of the young maize and possibly, too, the ripe grain, as he is often shown in conjunction with the sign Kan, the symbol of the harvest and maize food. Schellhas assigns him the letter $\mathrm{E}$ and suggests that he may be Yum Kaax, the lord of the harvest fields and patron of husbandry. He is invariably shown with a young maize plant as his head-dress and usually with a curved streak on his cheek. His features are well drawn, and he always has a youthful appearance, a welcome contrast to his fellow gods with their fantastic features.

There can be few more beautiful sculptures than that on the back of one of the stelæ at Copan which depicts the youthful handsome god peeping forth as he climbs the stalks of maize. The group gives one the impression that spring is in the air, and the whole spirit of joyfulness permeates the land-youth is in control.

By himself the young god was helpless; he was in the hands of the destinies who controlled the rain and drought. Sometimes we find him under the protection of the rain god, and sometimes he suffers persecution at the hands of the god of death in whose special keeping were drought and famine.

The god above all associated with death was god A (Fig. 2, No. 8, and Fig. 3, No. 7), Ah Puch. He is a god of the utmost importance, especially in view of the fact that Bishop Landa informs us the Mayas had 
an immoderate fear of death. He is represented as a skeleton with a very prominent spinal cord, and his head is replaced by a skull. Bones form his chief adornment, and he is frequently depicted with a sign that bears a striking resemblance to an ordinary percentage sign. He is found in other situations associated with death, and sometimes he is shown with a body covered with black spots, which undoubtedly represents decomposing flesh. He usually wears a feather collar with bells attached; the connection, however, between this ornament and death is not known.

Maya religion partook somewhat of the nature of dualism. We are constantly reminded of the unending struggle between the benevolent gods of life under the leadership of god $B$ and the malevolent powers of darkness under that of god A. God B is seen tending the young tree, god A comes behind and destroys it, typifying the eternal fight between the good and the evil; what the former achieves, the latter attempts to undo. As stated above, droughts were connected with god A. He was closely connected with a number of other deities, the gods of war and sacrifice, the ruler of the abode of the dead, and owls, which were the harbingers of death and the messengers of the ruler of the next world.

The Mayas believed very firmly in the existence of a future life beyond the grave, where each man got his deserts. Those who had lived good lives in this world, in the next found themselves in a heaven. They did not, however, believe in a resurrection of the body. This heaven was a delectable abode free from all sorrow and pain, where those who had been sufficiently lucky to arrive there were free to rest and enjoy themselves. There was feasting and dancing. In the centre grew a huge tree, in the shade of the enormous boughs of which the souls rested. 
Those who had lived evil lives were condemned to Mitnal which was situated below the abode of the good souls, Hunahau prince of the demons, ruled over this land. Existence there was endless, and we are informed that the inhabitants even lacked souls. They were condemned to undergo tortures which took the shape of hunger, exhaustion, cold, and sadness.

Suicides went to heaven, and were much respected. They were under the special patronage of the goddess Ixtab (Fig. 2, No. 9), who is represented in the codices with a rope around her neck. As a result of this belief, suicides were very frequent. It was a common practice for Mayas to commit suicide for some trivial matter, or as the result of slight depression, believing, as they did, that thereby a place in heaven was assured them.

These beliefs in a heaven and hell for the righteous and unrighteous may be due in part to the teachings of the friars; they are not typical of aboriginal American beliefs. Primitive peoples usually believe in only one abode of the dead. Where there is a belief in two or more, the better is usually reserved for the aristocracy or warriors.

A god closely connected with death is god F (Fig. 2, No. 10), who presided over war, human sacrifice, and death by violence. His characteristic emblem is a streak of black paint running in a vertical curve the length of his face on each side. This may possibly represent war paint or gaping wounds. It is interesting to note that the Mexican god of human sacrifice, Xipe, also bears a similar black stripe. In the codices god $\mathrm{F}$ appears as a companion of god $\mathrm{A}$. On one occasion the two are presiding over a sacrificial victim; on another god $\mathrm{F}$ is shown striding through the country with flaming torch in one hand, in the other a knife, as he follows god A on their destructive missions.

Goddesses are of minor importance. The goddess of suicides has been mentioned above, the only other 
goddess to whom much attention seems to have been paid is the goddess I. Her features are those of an old woman, her body is brown in color, and she has claws instead of feet. For a head-dress she wears a knotted snake, and frequently she is represented pouring water from a bucket. She may be merely a feminine counterpart of god $\mathrm{B}$, or possibly she represents the water spirit. However, the fact that she is on one or two occasions associated with the sky god D seems to point rather to a connection with rain.

Lastly a number of mythological animals occur. On the monuments of the Old Empire is depicted everywhere a two-headed monster. But no trace of the creature occurs in the codices. The body rather resembles that of a crocodile. At each end is added a head. In front the head bears a superficial resemblance to a crocodile's, but the jaws are very similar to those of a conventionalized snake. In the open mouth appears the head of the sun god, though occasionally god B takes his place. The rear head is very definitely characterized by the symbols of death and the Saint Andrew's cross, the emblem of the sun. The front head represents the sun rising from the earth; the tail head symbolizes the sun in the underworld, that is, its setting. During the night the sun travels through the body of the earth monster and emerges at sunrise from the front head.

Joyce produces good evidence to show that this animal is the earth monster similar to the Mexican symbolic earth monster which is often depicted as swallowing either Tonatiuh, the sun god, or Tlaloc.

Two-headed snakes are often shown on the monuments. Very often figures are shown bearing in their arms staves which in many cases are replaced by twoheaded snakes, probably a badge of high priestly or secular office. 
A few other animal and bird gods exist of relatively little importance, as far as we know at present. In most cases little is known beyond their appearance.

We have very briefly touched on a dozen of the most important members of the Maya pantheon. It remains to assign these gods to the two distinct categories of worshippers-priest and layman.

The Maya layman was polytheistic, but that does not necessarily imply that the priest also believed in a multitude of deities.

Polytheistic religions have a tendency to absorb more and more gods into the national pantheon. One has only to cite Rome to show how true this is. The Roman soldier returning from garrison duty in Asia or Africa introduced the gods and goddesses of the land he had subdued and occupied. The merchant of a nation subject to Rome visited the capital in connection with his business, and further helped to establish new deities. The only serious rival of Christianity was the religion of Mithra, an Asiatic god introduced into the empire and spread everywhere by Roman soldiers. The same is true of Mexico. The Aztecs foisted their tribal god, Huitzilopochtli, on the neighboring Mexican peoples, and transferred many of the attributes of the gods of the conquered peoples to their own special tribal deities, with the resulting confusion.

How true this may be of the Mayas it is hard to say. I have already suggested that the Mexican mercenaries may have been responsible for the re-introduction of Kuculcan in a modified form, and they were undoubtedly the introducers of many religious ceremonies, especially those connected with human sacrifice. I have also suggested that the number of gods may have been increased by a system of splitting. Under this hypothesis Kuculcan as god of rain becomes god $\mathrm{B}$, and as god of the wind, god $\mathrm{K}$. The same process 
was in operation in New Zealand among the Maoris before the introduction of Christianity. The creator god was assigned so many names and attributes that definite confusion ensued, and there seems little doubt that the layman who worshipped him as the god of one element under one name, quite failed to realize that he was exactly the same god as the one he worshipped under a different name as the controller of some other element. Kuculcan would recede more and more into the background as a fertility god, as his connection with gods $B$ and $K$ became less realized. The man with the priest complex, of course, would never lose sight of the fact that gods $\mathrm{B}$ and $\mathrm{K}$ were but manifestations of Kuculcan; the layman would.

The priest would be working in the opposite direction toward unification, and probably arrived at monotheism. One can imagine his line of thought. All the fertility gods are but manifestations of Kuculcan. The sun, the moon and the north star are just different sides of Itzamna, the sky god. The group of death gods are in the same way merely representations of the different forms of death. In this way he would reduce his gods to a trio. Realizing, as we know he did, the close connection between Kuculcan and Itzamna, it would be but a short step to arrive at the belief that they were but two manifestations of the heavens, the face turned earthward, and the part that can only come indirectly in touch with earth.

We know the Maya realized the dualism of his beliefs, and so we have grounds for thinking that the very close association between the beneficial gods and those connected with death, destruction, and famine was not merely fortuitous. God was two-faced, with one face smiling on his people, with the other frowning; with one hand dealing out the bountiful fruits of the earth, with the other hurling down evil and misery. This belief is met with in many parts of the American 
continent. Therefore, whereas the rank and file had still a firm belief in a large and possibly an increasing number of deities, the religious thinker had progressed far, and had probably reached the goal of monotheism. 


\section{QUICHE LEGENDS}

At the time of the conquest, there were a large number of tribes besides the inhabitants of Yucatan speaking Maya dialects. The most important of these are the Quiche and Kakchiquel, who lived around the northern, western, and southern shores of Lake Atitlan.

What influence the inhabitants of the Old Empire may have had on the Quiche and Kakchiquel is not properly known, owing to the almost entire absence of sculptural monuments from the Lake Atitlan area. But the close resemblance of the two calendars, and, to a lesser extent, of the religions of the two areas shows that a great deal of the Lake Atitlan culture must have been borrowed from the Old Empire, possibly through the inhabitants of Quen Santo. A significant passage in the Quiche legends, however, states that they went to visit their kindred peoples who lived to the east in order to obtain the insignia of rank; and this seems to point to earlier intercourse with the Old Empire.

Luckily a history of the Quiche has been preserved which in addition to the historical portions contains a great deal of legend and mythology of enormous interest to us, as undoubtedly they comprise a great deal of traditions, belief in which was shared with the Mayas of the Old Empire and other kindred peoples.

These traditions are known as the Popol Vuh, which means "collection of written pages," and were first committed to writing by a Christianized native. Afterwards they were copied and translated into Spanish by a monk, Jimenez. They were lost for a couple of centuries, like Landa's "Relaciones de las cosas de Yucatan," re-appearing after a long search in the middle of the nineteenth century, when they were dis- 
covered in a library in Guatemala. The Popol Vuh is divided into four volumes, of which the first two and most of the third are entirely mythical. The latter part of the third and the last volume give a highly colored historical account of the rise and prowess of the Quiche nation. The first book narrates how the world was created and the exploits of the divine twins.

Hunahpu, Gukumatz, and Hurakan were the creators. The first undoubtedly corresponds to the Yucatan Hunabku, the creator and father of Itzamna. Gukumatz is merely Kuculcan, the feathered serpent in the Quiche dialect. Hurakan was the wind god, and possibly was the same as god K.

These three took counsel, and decided to create the world. "Earth," they cried, and the earth appeared. Next animals were created, but the gods were not satisfied, as the animals were dumb and could not thank their creators. Accordingly, the gods fashioned men out of clay, but they had no intelligence, and displeased their creators, who destroyed them. Xpiyakok and Xmukane, the father and mother gods, were then called in to the deliberations. They decided to make small men of wood. This was done, but the wooden men were irreverent and mischievous, and the gods decided to destroy them. A flood was caused, the waters rose, and the rain poured down on the wretched little men of wood. Birds too attacked them, eating their bodies and tearing out their eyes. Every animal turned against them, even their domestic utensils joined in the persecution. The race was practically annihilated; only a few escaped, and became small monkeys, the ancestors of those that play to-day in the forests of Guatemala.

Here the story of the creation breaks off to relate the adventures of the divine twins.

After the flood there lived a terrible being, known as Vukub-Cakix, whose body seems to have consisted 
for the most part of gold, silver, and precious stones. $\mathrm{He}$ too was boastful and irreverent and angered the gods, who sent Hunahpu and Xbalanque to earth to deal with the nuisance. This Hunahpu is not the same as the creator mentioned above. Vukub Cakix was the possessor of a very fine fruit-tree, on which he depended to a large extent for his food. One day the heroes came on him as he climbed up to gather the fruit. Hunahpu promptly raised his blow-gun to his mouth and shot a dart at him. Vukub Cakix hit in the mouth fell out of the tree, and Hunahpu closed with him. In the struggle that ensued Vukub Cakix tore off his opponent's arm, and, breaking off the fight, strode home with it to his wife, who proceeded to wither it over a fire, chanting spells against Hunahpu the while.

In order to recover the arm, the two heroes join two sorcerers, and in disguise offer to cure VukubCakix of his damaged mouth. The injured giant is delighted, and willingly submits to their operations. They inform him that the only way to cure him is to remove all his teeth. He consents to having his teeth removed, but when he is tied down for the operation, they not only remove his teeth, but also his eyes, and as a result Vukub-Cakix dies. Hunahpu fixes on his arm again, and turns his attention to the two sons of his victim, Zipacna and Cabrakan, who are earthquake gods.

The divine heroes start to build a house with the aid of four hundred young men. Four hundred in aboriginal America signified "innumerable." They are engaged in dragging along a tree-trunk for one of the corner posts, when Zipacna comes along and offers to carry it for them. They persuade him to get down into the post-hole with the trunk, and then try to kill him by hurling posts on top of him. Zipacna escapes, however, and causes an earthquake which hurls the four 
hundred youths skyward, where they become the Pleiades.

Foiled in their attempt, the heroes next persuade Zipacna to visit a certain spot, and then throw a mountain on top of him. To make doubly certain they turn him into stone.

With one brother out of the way, the heroes next tackle Cabrakan, the surviving son of Vukub-Cakix. They invite him to a meal which consists of a bird baked in poisoned mud. Cabrakan eats the meal and subsequently dies. This concludes the first book.

The opening of the second book harks back to the adventures of two other divine heroes, Hunhunapu and Vukub Hunapu, father and uncle respectively of the twin conquerors of the giants. They were sons of the father and mother gods referred to above.

The brothers were very fond of the Mexican ball game, and in the course of play arrived near Xibalba which was the abode of the dead. The rulers of that land challenged them to a game. They accepted, but before play was possible, they were subjected to a series of pranks and ordeals. Crossing a river of blood, they entered the palace of the rulers of Xibalba, and catching sight of two seated figures, went up to greet them, in the belief that they were addressing images of wood. Invited to sit down, they sat on a red-hot stone. They then passed into the "House of Gloom," and were killed and buried. Hunhunahpu's head was hung up on a tree, from which were suspended a number of human face-like gourds. One day a princess of the realm of the dead approached the tree out of curiosity. Hunhunahpu's head promptly spat into her hand, and she became pregnant. Escaping to the land of the living, she gave birth to the heroes whose early deeds are related in book $I$.

Hunahpu and Xbalanque were in their youth great hunters, and incurred the jealousy of their half- 
brothers, Hun Batz and Hun Chuen. The twins, piqued by their enmity, turned them into monkeys. During their youth they performed a number of hazardous deeds and magical acts, and then they heard the story of the descent of their father and uncle into Xibalba and their terrible end.

Forwarned is forearmed, and consequently when the Lords of the Underworld challenged them to a game of ball, they were prepared for the worst.

They sent forward a small insect armed with a hair from Hunapu's body to prick all the figures in the palace, and so discovered which were of wood and the names of those that were not. Among many primitive peoples the knowledge of the names of opponents serves as a basis for a magical attack on them. As a result of the information thus obtained, they avoided the wooden figures and the red-hot seat, much to the chagrin of the Xibalbans. Sent to fetch flowers which were well guarded, they enlisted the services of ants, who cut down the flowers and brought them to the twins. Subsequently they passed successfully through the houses of cold, tigers, and fire, all of which contained ordeals, failure to overcome which means death.

In the house of bats misfortune overtook them. They were required to pass the night upright and motionless. There was no trouble until the night was nearly over, when Hunahpu unfortunately moved his head. The result was disastrous, A bat swept down on him, and with one slash of his beak tore off the hero's head. A tortoise took the place of the decapitated head which was suspended in the ball court. Xbalanque went out to play alone against the lords of Xibalba.

In the course of the game the Xibalban players mistook a rabbit which leaped out of its hiding-place in the court for the ball. They chased it as it scuttled away, and during their absence Xbalanque substituted 
his brother's head for the tortoise, and Hunahpu was restored to life.

The twins next showed their magical powers by killing themselves. Their bones were ground down and thrown into the water. They reappeared as fishes, and subsequently as old men. In this disguise they killed and resurrected each other, arousing the curiosity of the Xibalbans who also wished to experience the sensations of death and resurrection. The twins consented and killed the two leaders of Xibalba, refusing afterwards to restore them to life. This was the end of the struggle. The Xibalbans, thoroughly cowed, submitted to their conquerors. They were forbidden to play their ball game, and their sole diversions were to be the making of pottery and bee-keeping.

The souls of the first pair of brothers, their father and uncle, were released and became the sun and moon respectively, a fitting conclusion to the second book.

The third book resumes the interrupted story of the creation. The creators, disgusted with their former efforts to design man, decided to use maize this time as the material. There was some difficulty at first in finding the maize, but eventually, with the aid of various animals, it was discovered and ground down. From this four men were fashioned, but they proved too intelligent. Hurakan breathed a cloud over them, so that much might be hidden from them. In the course of a deep sleep, an equal number of women were created. These were the ancestors of the Quiche. The patriachs of other races were then created.

The world, however, was in twilight; no sun existed. In the course of long travels, during which they wandered across mighty mountain-ranges, suffering great hardships, they arrived at the mountain Hacavitz. There they were destined to see the sun. Even then it was but an attenuated sun, whose feeble rays scarcely lit up the world. The gods of the Quiche were 
turned to stone when its rays rested upon them, and the first town was built. Eventually the patriachs, the founders of the race, departed, leaving behind them a large bundle which was known as the "Veiled Majesty."

According to the legend, human sacrifice was a very early institution. The Quiche obtained fire from their great tribal god, Tohil, who, being a thunder god, was able to strike fire from his sandals as he rode in his cloud wagon across the heavens. The other tribes were without fire, and to obtain it had to supply victims for sacrifice which, were offered by the Quiche to their gods.

After narrating the departure of the patriachs, the Popol Vuh becomes a fairly truthful historical record of the Quiche. As is only natural, the Quiche almost invariably shine in comparison with their neighbors. 


\section{THE CALENDAR}

In considering the Maya calendar, it must always be borne in mind that the Mayas counted only elapsed time. In the same way that we talk of $1.50 \mathrm{p}$. m., because 2 o'clock has not yet struck, so the Maya, if one could imagine him in the centre of Chicago and cognizant of our calendar, would not speak of the first day of the year as January 1st, but he would call it January 0. Similarly our January 2nd would be to him January 1st. Although this may appear rather singular to us, it is at least consistent. Our system is certainly not consistent, as the day and months and years we count in current time and the hours and minutes in elapsed time. Our year 1927 would, in the opinion of the Mayas, be 1926 until midnight on December 31 st, and only then would he call it 1927 , because only then would the year be complete.

The Mayas marked the passing of the years by means of no less than four systems of counting time, which acted as checks one upon the other, so that if the Maya artist made a mistake of one day, we at the present time can instantly detect it, although in our own calendarial system to discover on what day of the week May 1st 1588 occurred would be an enormous task.

The four Maya systems were a year of 365 days, a year of 360 days, a period of 260 days, and a lunar year. The year of 365 days was divided into eighteen months of twenty days, to which a period of five days, which were considered extremely unlucky, was added to complete the year. For calculating the year of 360 days, these five days were omitted, and the year which was known as Tun was divided into 18 Uinals ("months"), each of 20 Kin ("days"). Twenty Tuns made a Katun, that is a period of 7,200 days; and 
twenty Katuns made a cycle (also known as Baktun) of 144,000 days, four hundred years of 360 days which make approximately 394 years of our system.

There was a still higher unit known as a great cycle which probably consisted of thirteen cycles, more than five thousand years; but as this is outside practical work, it can be ignored.

The sign for the Kin is similar to a Saint Andrews' Cross, which is the sign for the sun, or alternately the head of the sun god, Kinich Ahau, with his streaming beard and filed teeth (Fig. 5, Nos. 1-2).

The "month" hieroglyph is represented by the face, often highly conventionalized, of the frog. In one or two cases where the monuments show full figure hieroglyphs, the frog is faithfully depicted. In the head series the Uinal is recognizable by the prominent curl behind the mouth, and a circle containing three dots which is found as a rule behind the eye. It is interesting to note that the Zuyua (Maya) word for frog is Uo (Fig. 5, Nos. 3-4).

The Tun is in the face form shown as a bird with the bleached jawbone which is the sign associated with death (Fig. 5, No. 5).

The ordinary form of the hieroglyph has for long puzzled Maya students. The word Tun means "stone," and we are told that it was a Maya custom to erect a stone at the close of each year. I would suggest that the bird with the death sign is Tunculuchhu, a species of owl. The owl, as has been explained, was specially associated with death. The Tun sign bears a strong resemblance to the Moan bird, an ominous being in the eyes of the Mayas and which is generally believed to be a species of owl. In addition to this, the ordinary form of the Tun hieroglyph is strangely similar to the name glyph of the Moan bird (Fig. 5, No. 6).

The next highest period, the Katun, is represented by a symbol, somewhat similar to the Tun sign, except 


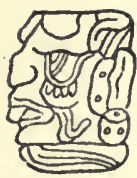

1

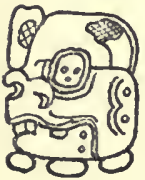

5

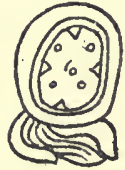

2

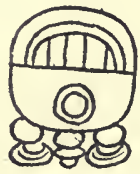

6
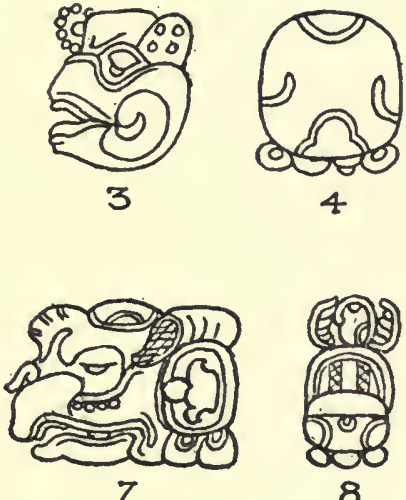

8

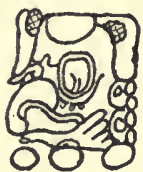

9

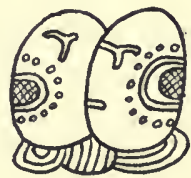

10

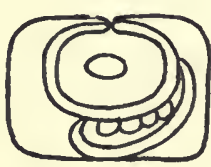

11

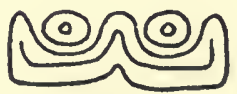

12

Fig. 5.

Maya Calendrical Hjeroglyphs.

1-2, Kin glyph; 3-4, Uinal glyph; 5-6, Tun glyph; 7-8 Katun glyph; 9-10, Cycle (Baktun) glyph; 11, Moon glyph; 12, Venus glyph. 
that on each side and above it. are often shown two small conventionalized fish, or fish bones (Fig. 5, No. 8). Here again phoneticism is probably involved as the Zuyua (Maya) word for fish was Kay; the whole sign thus reads Kaytun-Katun. The face form is that of a parrot combined again with the fish element (Fig. 5, No. 7). Often, too, the phonetic character is further strengthened by the addition of the Cauac sign.

The Baktun sign in its ordinary form consists of a double Cauac sign (Fig. 5, No. 10). In the head variant a species of parrot is again employed. The most important point to note is that almost invariably a hand covers or takes the place of the lower jaw (Fig. 5, No. 9).

The Grand Cycle sign has also as its basis the head of a bird. The so-called Initial Series rarely includes the Grand Cycle. First comes a large introductory sign, and then follow the cycle sign with its numeral, almost invariably a nine, then the Katun, Tun, Uinal and Kin signs with their respective numbers.

The dates on the monuments are usually read in pairs from left to right in double columns. The numbers are either expressed by heads, or by the so-called dot and bar method. The numbers up to four are expressed by dots, and from five onward by a combination of dots and bars. A bar represents five. Thirteen, therefore, is shown as two bars and three dots. The reader, however, is cautioned not to mistake for numbers certain small crescents which are merely used to fill up space. For instance, the number 6 is usually sculptured as a bar, a dot and two small crescents on each side of the dot. The crescents are entirely superfluous, and are introduced only to preserve the balance (Fig. 6).

Illustrations of the head variants are given also in Fig. 6. 

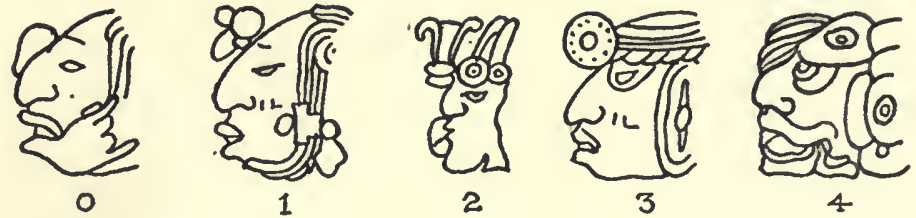

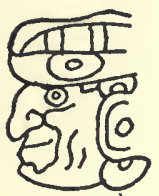

5

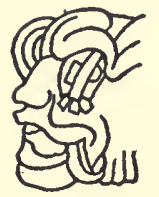

6
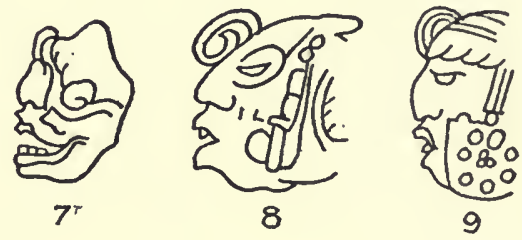

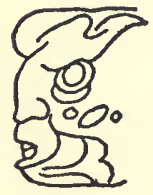

10

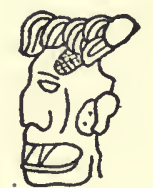

11
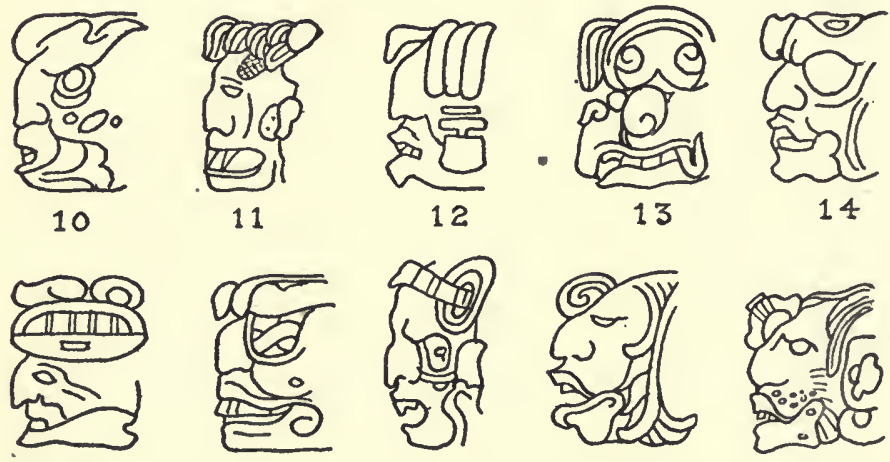

15
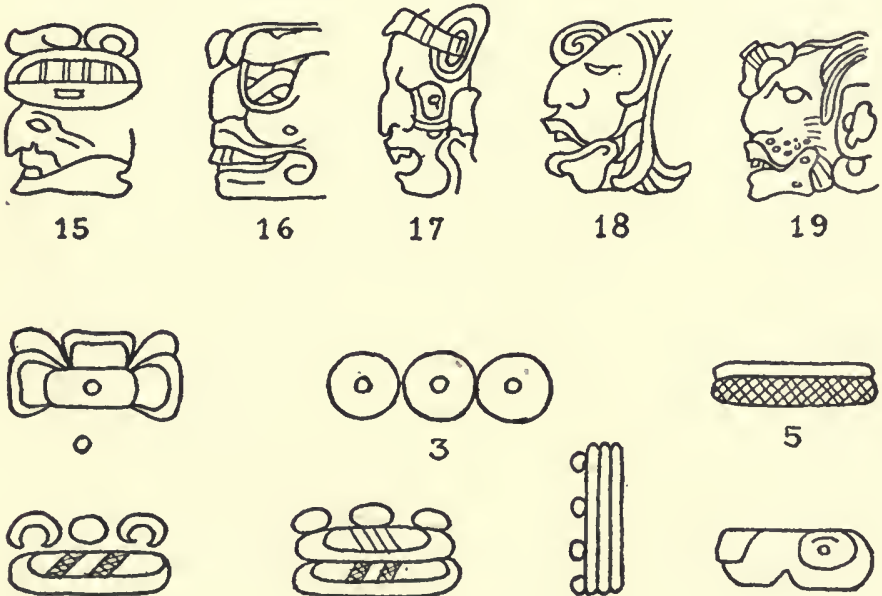

6

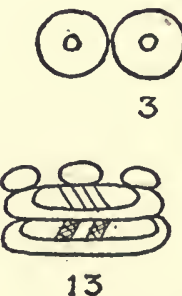

Fig. 6.

Maya Numbers.

Above head variants 0-19. Below "bar and dot" numerals and thumb variant"for 1 . After Joyce.

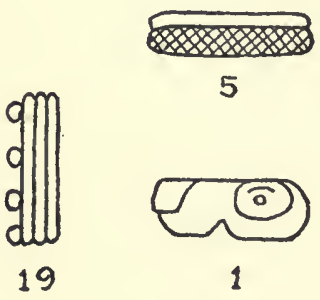

19 
It will be noticed that numbers from thirteen onward contain the characteristic features of the numbers three to nine respectively.

0 invariably had a hand over the lower jaw which it may be remembered is the characteristic mark of the cycle sign.

1 is distinguished by the two or three piece forehead ornament.

2 occurs only once in the Old Empire, at Piedras Negras.

3 is characterized by a banded hat.

4 bears a resemblance to the sun god sign. The filed teeth, projecting fang, and quadrangular staring eye are present.

5 wears a head-dress which is the Tun sign.

6 has an axe in its eye.

7 is very rare. It has, however, a peculiar scroll mark around the eye.

8 is distinguished by the spiral projecting from the forehead.

9 has a number of dots on the chin. Sometimes a beard occurs.

10 shows the characteristic bleached jawbone of the death god.

11 is seldom met with. The peculiar head-dress may be the characteristic symbol.

12 has a projecting lower lip.

13 is either a combination of 3 and 10, or a bird-like animal with a very prominent beak and a fang projecting from the mouth.

The numbers from 14 to 19 are represented with the head for the second digit with the jawbone characteristic of 10. Zero is also expressed by the sign shown in Fig. 6, and one is shown by the so-called thumb sign (Fig. 6). 

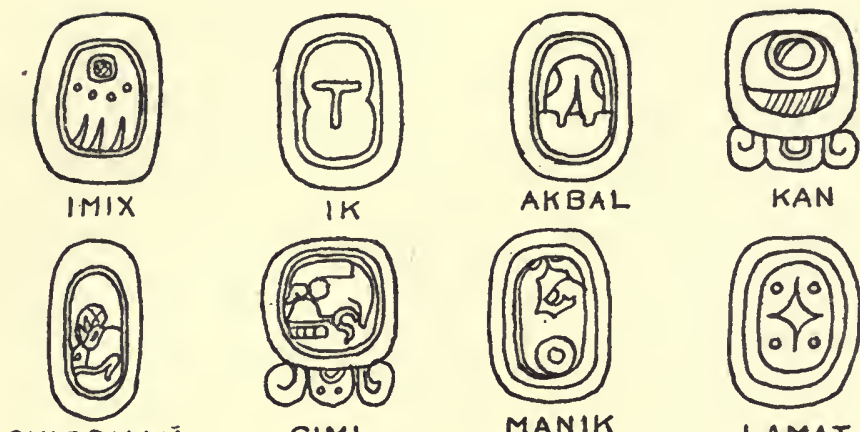

KAN
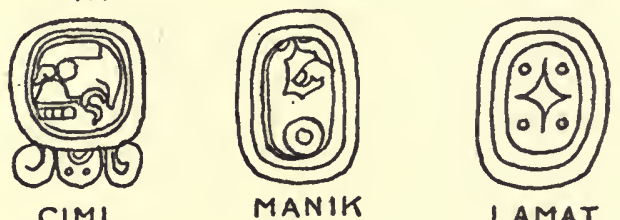

CHICCHAN

CIMI
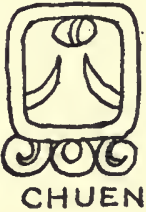

LAMAT

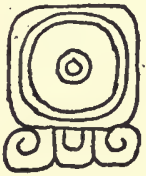

MULUC
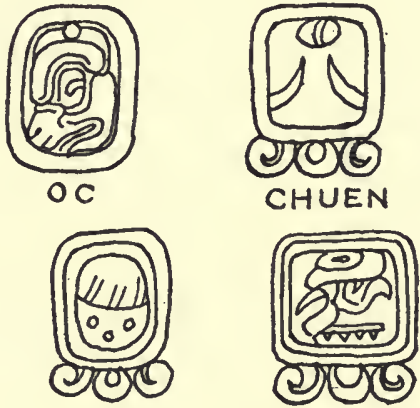
MEN
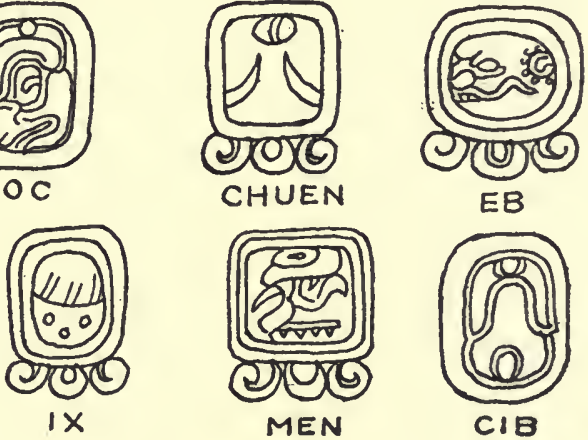

BEN
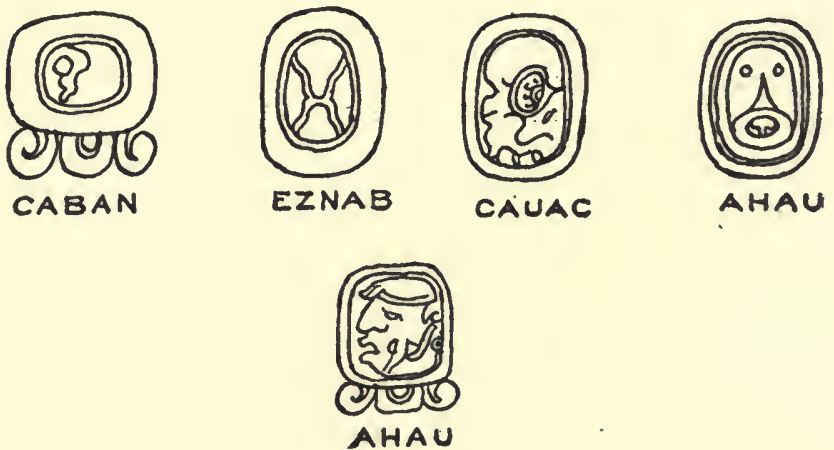

Fig. 7.

Maya Day Signs from the Monuments. After Joyce. 
Reverting to the calendar, we have yet to deal with the 260-day count. The original name for this period has been lost. It is, however, usually known by the name Tzolkin or more usually by the rather inappropriate corresponding Mexican word, Tonalamatl. The Tonalamatl consisted of a series of twenty signs with which the numbers 1-13 were combined. The days with their correct sequence are illustrated in Fig. 7. The numbers 1-13 and the twenty days kept repeating themselves through all eternity.

A short example of how the system worked is given below:-

\begin{tabular}{|c|c|c|}
\hline $\begin{aligned} 13 & \text { Imix } \\
1 & \text { Ik } \\
2 & \text { Akbal } \\
3 & \text { Kan } \\
4 & \text { Chicchan } \\
5 & \text { Cimi } \\
6 & \text { Manik } \\
7 & \text { Lamat } \\
8 & \text { Muluc } \\
9 & \text { Oc }\end{aligned}$ & $\begin{array}{rl}10 & \text { Chuen } \\
11 & \mathrm{~Eb} \\
12 & \mathrm{Ben} \\
13 & \mathrm{Ix} \\
1 & \mathrm{Men} \\
2 & \mathrm{Cib} \\
3 & \mathrm{Caban} \\
4 & \text { Eznab } \\
5 & \text { Cauac } \\
6 & \text { Ahau }\end{array}$ & $\begin{array}{rl}7 & \text { Imix } \\
8 & \mathrm{Ik} \\
9 & \text { Akbal } \\
10 & \mathrm{Kan} \\
11 & \mathrm{Chicchan} \\
12 & \text { Cimi } \\
13 & \text { Manik } \\
1 & \text { Lamat } \\
2 & \text { Muluc } \\
3 & \text { Oc }\end{array}$ \\
\hline
\end{tabular}

In addition to these day signs combined with the numbers 1-13, there were eighteen months of twenty days and a short five-day month at the end of the year to complete 365 days. The year opened with the month Pop, which at the time of the Spanish conquest fell on July 26th (Gregorian). As the Mayas used no leap year intercalation, the position of New Year was continually shifting in the tropical year.

The months were as follows (see Fig. 8) :-

$\begin{array}{llll}\text { Pop } & \text { Xul } & \text { Zac } & \text { Pax } \\ \text { Uo } & \text { Yaxkin } & \text { Ceh } & \text { Kayab } \\ \text { Zip } & \text { Mol } & \text { Mac } & \text { Cumhu } \\ \text { Zotz } & \text { Chen } & \text { Kankin } & \text { Uayeb (5 days only) } \\ \text { Tzec } & \text { Yax } & \text { Muan } & \end{array}$

The Uayeb month of five days was considered very unlucky, and during its course all work was avoided as far as possible.

The twenty days of the month were indicated by the numerals 0 to 19. The first day of the year was 

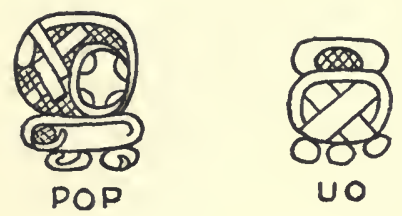

บo

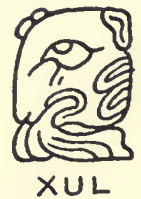

TZEC

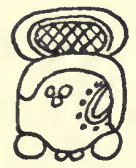

CHEN

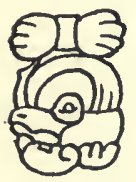

MAC

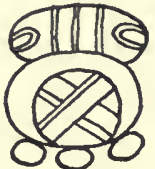

ZIP

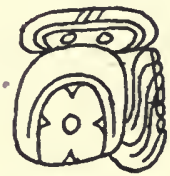

YAXKIN

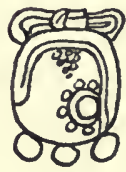

ZAC

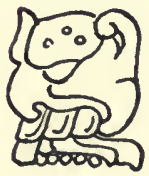

MUAN
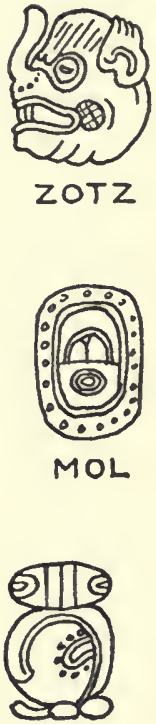

CEH

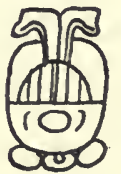

PAX

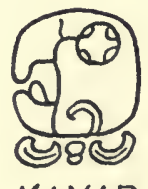

KAYAB

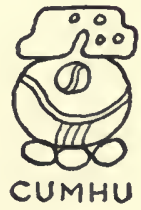

Fig. 8.

Maya Month Signs from the Monuments.

$$
\text { After Joyce. }
$$

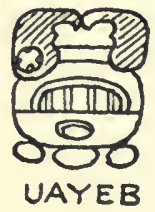

UAYEB 
0 Pop; and the last day, 4 Uayeb. The last day of the month Pop, 19 Pop, was followed by 0 Uo, the first day of the second month.

The Mayas may then be said to have used a system to denote a day which might be freely translated as 3rd Wednesday, January 23rd. Whereas Wednesday recurs every seven days in our calendar. The system of combining the day with thirteen numbers ensures that the day sign can recur only once in two hundred and sixty days.

In the course of the 365-day year, the day signs will each be repeated eighteen times, but there will be a surplus of five days at the end of the year $(365 \div 20$ $=18+5$ days), so that each year New Year's Day will start with a sign five places farther down the list, at the end of four years returning to the original place.

These four signs were known as the year bearers, and were in the epoch of the Old Empire the signs Ik, Manik, Eb, and Caban. Later in the New Empire they were shifted forward one position, and just about the time of the Spanish conquest they seem to have undergone another shift, Kan, Muluc, Ix and Cauac becoming the year bearers.

The Haab (365-day year) and the Tonalamatl in their relationship may be compared to two cogwheels, one of 365 teeth, the other having 260 teeth. Each tooth represents a day. If we put our wheel into motion with the tooth 0 Pop fitting into the socket $2 \mathrm{Ik}$, to take an example at random, when the large cogwheel has made one complete revolution, the smaller wheel will have made a revolution, and will have progressed another 105 cogs (the difference between 365 and 260) to the sign 3 Manik. The cog-tooth 0 Pop will only fit into the socket $2 \mathrm{Ik}$ after 52 revolutions of the wheel, that is 52 years of 365 days.

So we see the same combination of months and days with their respective numbers can occur once only 

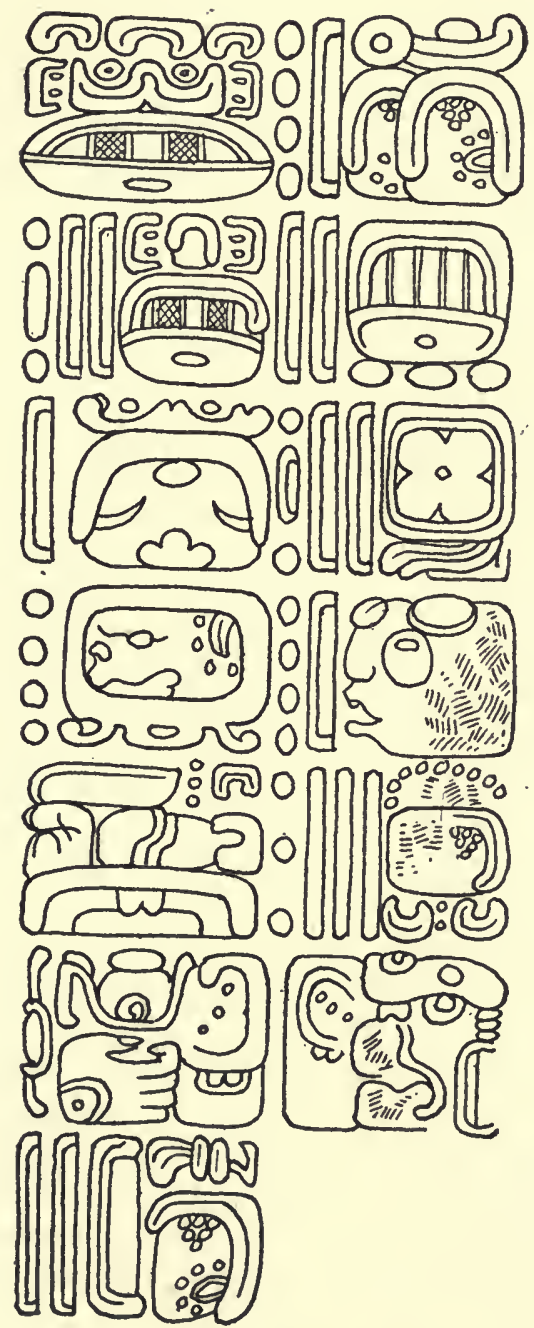

Fig. 9.

A Long Count Date. Stele 24 at Naranjo. After Morley. 
in 52 years. This period is known as the calendar round. When these signs are combined with their respective Kin, Uinal, Tun, Katun, and Cycle signs, they form the usual full method of reckoning of the Old Empire, and can occur only once in all eternity.

All dates in Maya history, with two or three insignificant exceptions, are reckoned from the date 4 Ahau 8 Cumhu (3113 B.C.), which was probably a mythical date of the same class as the arbitrary date of the foundation of Rome used by the Romans in their system of reckoning. Let us take a trial date and test its accuracy. On Stele 24 at Naranjo there is a date which reads, "9 Cycles, 12 Katuns, 10 Tuns, 5 Uinals, 12 Kins, 4 Eb, 10 Yax," usually written 9-12-10-5-12. 4 Eb, 10 Yax (Fig. 9).

$\begin{array}{rlr}9 \text { Cycles of } & 144,000 \text { days }= & 1,296,000 \text { days } \\ 12 \text { Katuns of } & 7,200 \text { days }= & 86,400 \text { days } \\ 10 \text { Tuns of } & 360 \text { days }= & 3,600 \text { days } \\ 5 \text { Uinals of } & 20 \text { days }= & 100 \text { days } \\ 12 \text { Kin of } & 1 \text { day }= & 12 \text { days }\end{array}$

\section{Total $\overline{1,386,112 \text { days }}$}

Calculating 1,368,112 days from the date 4 Ahau 8 Cumhu, the date $4 \mathrm{~Eb} 10 \mathrm{Yax}$ is reached, which is the same as that shown on the monument.

Lastly, the Mayas fixed their dates by a lunar count, reckoning moons in groups of five and six. They stated how many days after a new moon the date in question was, how many moons of the group had been completed, and whether the actual moon, then running its course, was of 29 or 30 days. The lunar period is slightly over 291/2 days, but the Mayas reckoned in alternate 29 and 30 day periods, inserting an occasional extra 30-day period to counterbalance the fraction over $291 / 2$ days that form the lunar period. The moon sign is shown in Fig. 5, No. 11. 
The planet Venus (Fig. 5, No. 12) was the object of an important cult. The revolution of Venus occupies a little less than 584 days; five of these Venus years equalled eight mean solar years $(584 \times 5=2920$, $365 \times 8=2920$ ).

The Mayas, however, were well aware that the Venus year was actually less than 584 days. They knew its length to the second decimal point. The actual period is $\mathbf{5 8 3 . 9 2}$ days, and to correct this error the Maya dropped four days at the end of every sixty-one Venus years, and at the end of every three hundred Venus years eight days were dropped. This system was so accurate that had the Maya Venus calendar continued to function uninterruptedly up to the present day, the error over this period of over a thousand years would not have amounted to more than a day.

Such an accurate knowledge of the cycle of Venus, the revolutions of which are by no means regular, points to centuries of sustained observations. Up to the present no deity in the Maya pantheons has been satisfactorily identified with Venus. In Mexico, however, Quetzalcoatl was closely associated with Venus as the Morning Star.

In addition to Venus, the planets Mars, Mercury, and Saturn were closely observed, and their phases accurately calculated. When one recollects that the Mayas were dependent solely on the naked eye for their observations, one is astounded at the grasp they had on the movements of the heavenly bodies.

In various cities regular lines of sight existed for the observation of the equinoxes, solstices, and other important points of the tropical year, notably at Uaxactun, Copan, and Chichén Itzá. The study of Maya numeration, astronomical knowledge, and calendarial systems is a science which has already produced sufficient books to fill several shelves. Within the limitations of this book it is impossible to give more than a 
bare outline of this fascinating subject. Readers who wish to go more deeply into the subject are referred to the list of books on the subject given in the bibliography. 


\section{RELIGIOUS CEREMONIES AND HUMAN SACRIFICE}

The priesthood among the Mayas was divided into at least four important divisions known as $\mathrm{Ah}$ Kin Mai, Chilan, Nacon, and Chac. Ah Kin Mai, known also as Ahau Kan Mai, was the high priest par excellence of the Mayas. He was held in very high esteem, and the whole community, both priests and laymen, contributed to his support. He officiated only at the most important religious ceremonies, and seems to have been more concerned with the scientific and astronomical side of religion. He was consulted by the nobility on important matters and tendered his advice. $\mathrm{He}$ was in charge of the education of candidates for the priesthood, to which as a rule the second sons of the nobility were dedicated. The education consisted of instruction in the calendar, the feasts and ceremonies, the administration of the sacraments, the occurrence and significance of lucky and ill-omened days, history, methods of divination, cures for illness, and finally reading and writing.

Under him were the Chilans, who constituted the regular priesthood. They fulfilled the regular functions of priests. They officiated at the feasts and sacrifices, administered the sacraments, preached and served as mouth-pieces for the oracles of the gods. In addition to their duties as priests and soothsayers, they also acted as medical advisers to the populace. The chief method employed was bleeding, though doubtless evil spirits were also exorcised.

A grade lower were the Nacons, whose sole function was to open the breasts of the sacrificial victims, tear out their hearts and pass them on a plate to the Chilan. The Nacons held their office permanently, but 
there was also a post of great importance which was held for a period of three years, and the holder of which was also known as Nacon. This position was, however, pre-eminently a military one, combined to a certain extent with priestly duties and abstinence. Good generalship was useless without the aid of heaven, and for that reason the functions of priest and general were blended, thus insuring, to paraphrase Napoleon's remark, that the gods were on the side of the well-led battalions.

The Chacs were old men, four in number, who were chosen afresh each time to aid the priests in their duties on the occasions of feasts and public sacrifices. Among their manifold activities was the duty of holding down victims on the altar as the Chilan plunged his knife into their breasts.

Human sacrifice, it would appear, was not a general custom in the cities of the Old Empire. Among all the scenes depicted on the monuments, only one would seem to refer to this practice. This is found at Piedras Negras, which owing to its proximity to Campeche and Tabasco may have been influenced by the customs of the Mexican immigrants. Surely human sacrifice, which must have been the culmination of the religious rites of any nation who indulged in it, would have been the theme of many sculptures if it was in fact practised. Scenes showing richly garbed priests are numerous on the monuments of Central America, and there are several representations of the practice of blood-letting by piercing the tongue and ears.

It would seem, therefore, that human sacrifice was introduced by the Nahua mercenaries who settled at Chichén Itzá. However, the practice never reached the enormous proportions it achieved in Mexico under the Aztecs.

Prisoners of war were sacrificed, and when these were not forthcoming, the community often subscribed 
to buy slaves. In times of dire distress the more devoted members of the community even offered their own sons. Until the day appointed for the sacrifice the victims were well treated, although strictly guarded, and were taken through the land in triumphal procession from town to town with much feasting and dancing. Meanwhile the Chilan and all others who were to take part in the coming festival had to undergo a period of rigorous abstinence and fasting. There were various methods of sacrifice employed, of which the arrow sacrifice must have been the most aweinspiring.

On the fatal day all gathered in the courtyard of the temple where the victim was stripped naked and his body smeared all over with a blue unguent, his only clothing consisting of a special pent-shaped headdress. Then, armed with bows and arrows, the whole congregation danced with the victim, revolving round a large stake. Whereupon the unhappy man was raised to the stake and tied to it, while the people continued to dance round and round. The priest then approached him and with a sharp stone knife made a wound in the victim's loins, and with the blood that gushed out the priest next anointed the features of the god. At a given signal the crowd, who had never ceased to dance, raised their bows and arrows, and as each man whirled by the victim in the mad dance he discharged an arrow into his heart which had been previously marked with white, so that the arrows stood out like the stamens of some gigantic sunflower.

A more usual method of sacrifice was by removing the heart. In their first part the proceedings were similar to those of the arrow sacrifice. The victim was stripped, painted blue, crowned with the peculiar headdress, and brought to the temple courtyard. The evil spirits were driven away, and the round sacrificial altar was also smeared with the blue ointment. Then 
the four Chacs seized the victim, placing him on his shoulders on the stone, each Chac holding one limb. The Nacon then approached with a stone knife and plunged it into the ribs just below the left breast. Quickly thrusting his hand into the aperture, he wrenched out the still palpitating heart which he placed on a plate and handed over to the Chilan. Passing swiftly to the idol near-by, the priest smeared its face with the fresh blood. This account is taken from Bishop Landa; such an operation would, on physical grounds, have been extremely difficult. Sometimes this sacrifice was made on the top platform of the temple. In this case the body of the dead man was thrown down to the junior priests below, who quickly removed the skin, save that of the hands and feet. The Chilan thereupon exchanged his robes for the skin and, clad in it, danced solemnly with the congregation.

Sometimes the bodies of the victims were buried in the courtyard of the temple, or sometimes the body was divided among the nobility and those who were near at hand, and was solemnly eaten. The Chilan reserved for himself the head, hands, and feet. In any case the victim by his method of dying became very holy. When a prisoner of war had been sacrificed, his captor retained the bones and wore them on state occasions as a mark of prowess. The sacrifices were not confined to one sex, women were equally eligible, and were in fact often sacrificed.

All these rites described above were practised by the Aztecs and other Mexican peoples at the time of the Conquest.

At Chichén Itzá a peculiar form of sacrifice was practised. Victims were thrown alive into the deep natural wells of that locality. People seem to have come from great distances to attend these ceremonies, and used to hurl their valuables into the water. Recent dredging operations have brought to light great quan- 
tities of human bones, jade, and gold, including objects which are of Costa Rican technique.

Individuals practised various forms of sacrifice by blood-letting. The most common form consisted of passing a cord into which were knotted a number of thorns, across the surface of the tongue. The blood which flowed as a result of this was smeared on the gods' faces. Cheeks too were often pierced, and ears were cut round and left hanging.

Women, although very religious, did not apparently practise these forms of sacrifice.

For minor festivals, animals, fish, and birds were sacrificed. Sometimes the heart was removed; on other occasions the animal was offered whole, either alive or dead. It was not an unusual practice, either, to cook the animals. However, whatever the process, the same custom of smearing the idols with the victim's blood was invariably followed. In addition maize cakes and every kind of dish or drink were offered, and copal incense was burnt.

The ceremonies that ushered in the New Year were of special importance and varied according to the day on which the year began. As has been explained, these could only consist of four which had in some way been shifted from the days Ik, Manik, Eb, and Caban, the year bearers of the Old Empire, to the days Akbal, Lamat, Ben, and Eznab, and at the time of the sojourn of Bishop Landa in Yucatan they seem to have been shifted a place further to the days Kan, Muluc, Ix, and Cauac. Kan was associated with the East; Muluc with the North and Kinich Ahau, the sun god, Ix with the West and Itzamna, the sky god; and Cauac with the South and one of the death gods. The first two were considered lucky years; Ix and Cauac, unlucky.

The New Year ceremonies commenced in the Uayeb days of the old year. The ceremonies connected 
with a Kan year were as follows. A hollow earthen image of Kan-U-Uayeb was first made and carried to the pile of stones at the south gate of the city (the south was associated with the dying year). One of the nobility was chosen master of ceremonies. In his house all the feasts were held, and here a statue was raised of Bolon-Zacab, who presided over the coming year. Next the whole community sallied forth to the south pile of stones along the road which previously had been adorned with arches and palm branches. Arrived at the spot, the priests incensed the figure of Kan-U-Uayeb with a mixture of copal and maize, and sacrificed a young turkey. The image of Bolon Zacab was then raised on a stick, and on top was placed a ray-fish as a sign of water. Dancing and rejoicing, the throng carried it to the noble's house where it was set up in front of the image of Kan-UUayeb. Offerings of animals, fish, and drink were then made, and the food subsequently was divided among the visitors, the priest receiving as his share a haunch of venison. Besides this, others cut their ears and smeared the idols with their blood and offered heart-shaped loaves of maize meal, or of calabash seeds. These ceremonies were kept up during the five days of Uayeb. Failure to carry out the ceremonies to the letter would invoke the wrath of the gods.

On the first day of the New Year, 0 Pop, BolonZacab was carried to the temple and Kan-U-Uayeb to the East Gate, where he watched over the interests of the city during the ensuing year. When this ceremony was completed, the people returned to their homes to celebrate the New Year in the family circle.

In case the year might still not prove favorable, further ceremonies ensued. The oracle bid the populace make an image of Itzamna Kauil which was put in the temple of the patron god of the year; incense was burnt, and a dog or a man was sacrificed. The method 
varied somewhat from those usually employed. A large heap of stones was raised in the temple courtyard onto which the bound victim, whether man or dog, was hurled from a greater height; then immediately the Nacon rushed forward and removed the heart in the usual manner, and the blood was smeared on the image. A special feature of these additional ceremonies was a dance of old women who were specially chosen and wore a distinctive dress. A spirit was said to descend and receive this sacrifice.

If, however, even after these ceremonies the coming year should prove unfavorable, the deity was excused on the grounds that the ceremony had not been properly carried out.

Somewhat similar ceremonies ushered in the New Years associated with Muluc, Ix, and Cauac.

The Muluc years were the occasion of a special dance on high stilts and a dance of old women with terra-cotta dogs in their hands. These ceremonies are depicted in the Troano-Cortesianus Codex with great clarity.

The Ix years were considered to bring in their train famine, eye-sores, and illnesses, if the ceremonies were not duly observed. The only compensation was the promise of an abundant cotton harvest. Drunken carousals were the order of the day, and were considered to have an appreciable effect in mitigating the evils of this unpropitious year.

The Cauac years were characterized by a special dance which endured all day. A hollow mound of wood was erected having entrances, and on top a man sang and beat the drum, while the congregation danced below. In the evening the pile was burnt and the embers smoothed out. As the dance continued, the more courageous and fervent walked across the hot embers. Although badly burnt, they earned the admiration of their fellow men and the appreciation of the gods. 
During the course of the year feasts were being continually held to propitiate special gods to obtain rain or good harvests, or to pay respect to the patron god of some specialized occupation.

In Zip, for example, both the sorcerers and fishers held feasts.

In the last quarter of Xul, the great feast of Kuculcan was held at Mani, although until the destruction of Mayapan it was held at that city. The other cities took it in turn to send deputations with four or five plumed banners which were carried in solemn procession to the gaily decked temple of Kuculcan and placed on the roof of the building. Offerings of food, drink, and incense were made, and the ceremony of kindling new fire took place. A number of buffoons took part in the ceremonies and passed round from house to house, entertaining the people and collecting money for the temple. As a matter of fact, the offerings were eventually divided between the priests, the nobility, and the mummers. On the last day of the feast Kuculcan was believed to descend from the sky and receive the offerings made to him.

A festival in honor of all the gods was held in the month Mol. Besides the usual sacrifices and offerings, the tools of every craft and the domestic utensils were painted with the holy blue ointment. The children too were painted, and had nine raps administered them on their wrists by an old woman dressed in a feather robe. The object of this ceremony was to ensure that the children grew up experts each one in his or her trade.

In either the month Chen or Yax the temple of the Chacs was renovated. If necessary, the clay images and braziers were replaced.

An interesting festival was held in honor of the Chacs and Itzamna in the month Mac. A large fire was lit in the courtyard of a temple, and into it were 
cast the hearts of every possible species of wild beast, bird, or reptile, from lion, puma, and jaguar to crocodile and lizard. If the hearts of some animals could not be obtained, imitation substitutes were fashioned out of incense. As soon as all the hearts were consumed, the fire was put out with jugs of water, and this would cause the year to be one of plentiful rain. This is a clear case of sympathetic magic.

Warriors had their especial feasts in the month Pax in the larger cities. The priests and nobility fasted for five days. The military Nacon was carried with great pomp and display to the temple amid clouds of incense. A special war dance was performed, a dog was sacrificed, and jars full of wine were ceremonially broken by the Chacs. The feast concluded with a great orgy of drunkenness in which the only man to remain sober was the Nacon, who, during his period of office, was forbidden to get drunk.

There were a large number of other feasts of varying importance and interest.

The Spanish friars were surprised to discover that confession was practised among the Mayas, as well as a form of baptism described in another chapter. The number of similarities between the two faiths led them to believe that St. Thomas had preached the gospel in these parts and that after some fifteen hundred years of degeneration Christian practices still remained. However, there is not the slightest reason to believe that Christianity even reached the New World before the arrival of Columbus.

Confession was usually postponed until illness frightened the people into confessing. In the absence of a priest, parents could hear their children's confessions, or a husband his wife's, and vice versa. If a number of sins were omitted, relatives or near friends prompted the confessor. Robbery, homicide, adultery, and false witness were the chief sins, but 


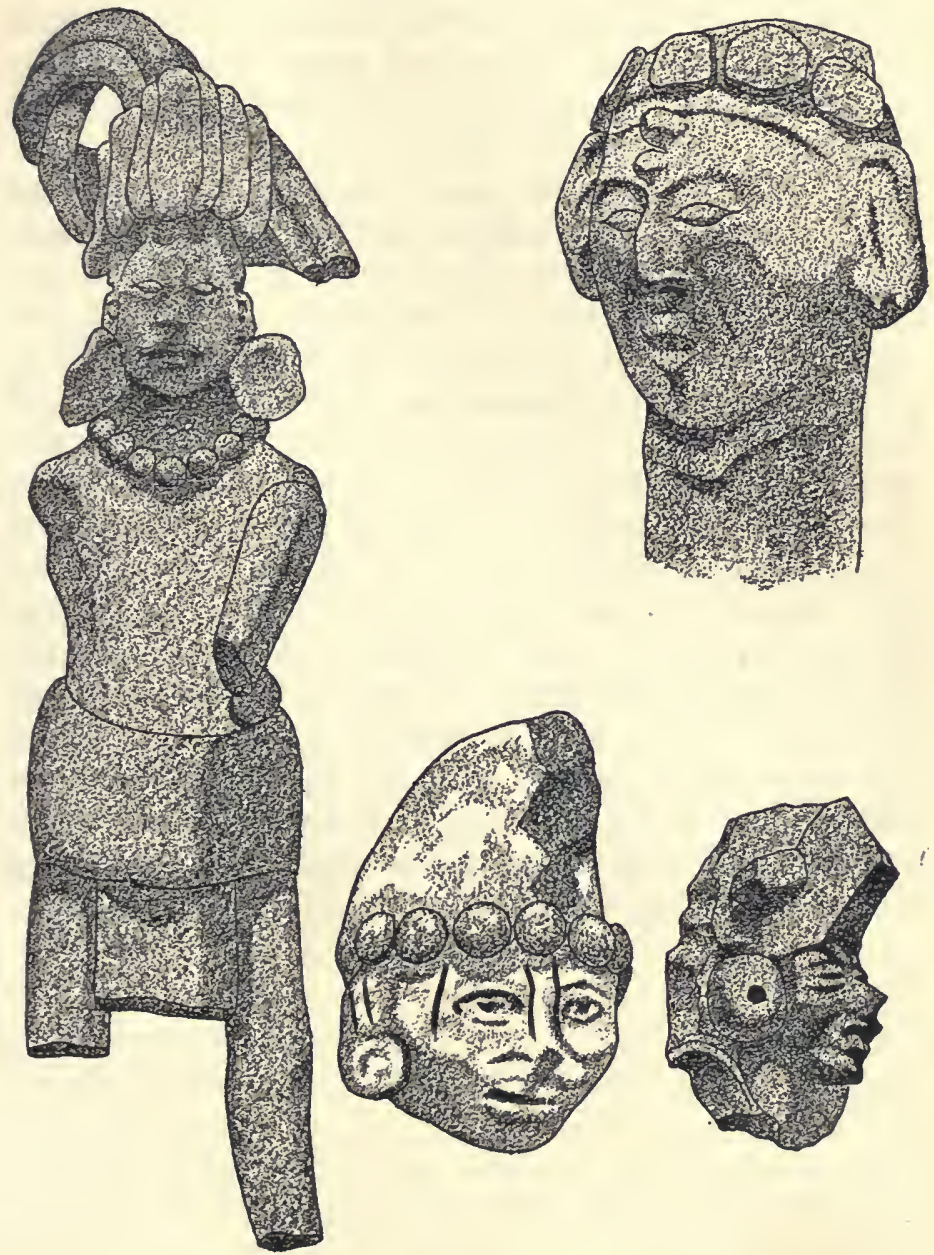

Fig. 10.

Maya Figurines. Above from Palenque. Below, left, from Chichen Itza. Below, right, from Xkichmook.

In Field Museum (Hall 8, Case 14). 
strangely enough premeditated sins were not confessed. A favorite form of fasting took the form of eating saltless and pepperless dishes, and sometimes meat was not eaten. Travellers invariably carried incense with them, and members of the nobility possessed their own private oratories.

It is interesting to note that a number of these ceremonies are still practised among the Lacondones, who are direct descendants of the ancient Mayas, inhabiting the valley of the Usamacinta. At present the engulfing wave of western civilization laps around them, but has not yet succeeded in sweeping away the tenacious vestiges of the old religion. These modern Mayas still make pilgrimages to the sacred sites of their ancestors and burn copal amidst the abandoned ruins and sprawling tree trunks. The censers are still renewed year by year, as they were before the arrival of the Spaniards. Stone images of the gods are still handed down from father to son. It is comforting to think that the worship of the old gods of the Mayas still lingers on in outlying parts. The god of the harvest rains, and the god that rides on the storm cloud are still looked up to and worshipped with the young god of maize and the great sky god. 


\section{SOCIAL LIFE}

Most primitive peoples show a tendency to accentuate any little differences that may mark them off from their neighbors. Some tribes practise tattooing or scarification, others dress their hair in a special manner, or adopt some distinctive clothing. The Mayas were no exception. Naturally an extremely broadheaded people (Plate XIV), they practised skull deformation further to differentiate them from their neighbors, some of whom were markedly narrowheaded.

Four or five days after birth children were placed mouth downward on a small cradle constructed of wooden 'boards, a board was then tied to the back of the head, and another to the forehead, and these two boards were tightly lashed together, so that the head, unable to grow normally, had to expand in the only possible direction, upward. The effect of this operation was to give the Mayas sugar-loaf heads, and this is confirmed by the sculptures on the monuments which invariably depict the people with a receding forehead that forms a straight line with the nose.

Squinting too was considered a sign of beauty, and was deliberately caused by the mothers, who suspended some small object from their children's hair, which, dangling between the eyebrows, had in time the desired effect.

Beards were not popular, and the Maya mothers are said to have scalded the faces of the boys with hot cloths to prevent hair growing. No wonder, Bishop Landa says, the children were brought up in a rough manner.

Up to the age of five or so they went about naked, and were very jolly and mischievous children. Landa tells us their dark complexion was due to two causes, 
the sun and too many baths. In mediæval times Europeans were little acquainted with water, and the early Spaniards were surprised and pained to see how the Mayas were perpetually bathing.

A form of baptism was practised, the word for which is zihil, which means "rebirth." Notice of baptism was given by the parents to the priest, and a day was decided on, care being taken that the day was not an unlucky one. The courtyard of the house in which the ceremony was to be held was swept clean and strewn with leaves, and the children were gathered there, the boys in one group, the girls in another. A godfather looked after the former, and an old woman acted as godmother for the latter.

The house was purified, and the evil spirits driven out by an elaborate ceremony. The four Chacs took up positions in the different corners, and sitting on small wooden forms stretched a cord from one to the other, forming a square within which were the children. The parents of the children then entered. In the centre was the priest seated by a brazier, and as each child came up to him, he handed him or her a few grains of maize and incense, which the child threw on the brazier. When this was concluded, a bundle was made of the brazier, the ropes, and a bowl of wine, and given to a man to take out of town without drinking or looking behind him. In this way the evil spirits were cast out.

The leaves strewn on the courtyard were then changed, while the priest dressed himself in his plumed robes. Next the Chacs placed white cloths on the heads of the children, and bid them confess any important sins they might have committed. When this was concluded, the priest blessed the children and sprinkled water on them with a short, carved stick, and the noble who presided over the ceremony gave each child nine sharp taps on the forehead with a bone, and then rubbed perfumed water on their faces and between 
their fingers and toes. Subsequently, the boys were made to smell a bouquet of flowers and draw some mouthfuls of smoke, and were given food to eat. Offerings and orations were made to the gods, and at the conclusion of the ceremony gifts were made by the parents to the participants, and a great feast and drinking orgy was held.

Marriage took place when the young man reached the age of twenty. Parents usually looked out for a suitable bride, if possible in the same district, and the services of professional match-makers were invoked. When a suitable girl had been obtained, a present was made by the young man's father to the bride's parents, and the mother in addition made garments for her son and future daughter-in-law. The wedding took place in the house of the bride's parents, the priest assured himself that all parties were willing, and a feast was then held, which constituted the marriage service. The husband lived with his father-in-law for a period of five or six years, working for him. The wife was responsible for preparing food and drink for her husband. Widows and widowers remarried with little ceremony. A meal taken by a widower in the house of a widow was all that was required to make the marriage binding. Polygamy was never practised, but desertion and divorce were very common. Marriage between cousins was permitted, but marriage with sisters-in-law or mother's sisters was considered very wrong.

Apparently there was no punishment for desertion, which frequently occurred even when there were children in the family. A man convicted of adultery was handed over to the injured husband, who could either forgive him or kill him. In the latter case the husband hurled a large stone down onto his head from a height. The disgrace and infamy with which she was branded was considered sufficient punishment for 
the woman. However, on the whole, the women were very chaste and hard-working. They shared with many other primitive peoples the custom of avoiding men, as we are told that they turned their backs when they met a man by chance, and the same occurred when they gave food or drink to any man. Bishop Landa tells us also that they were jealous, and although usually quiet, if provoked they flew into a violent temper. They took charge of the education of their children, and punished them by pinching their arms and ears, or by rubbing a species of stinging pepper (Capsicum) on them. Like their husbands, they were fond of getting drunk, but these orgies were held in private, and no men attended; similarly they ate apart, and never shared a meal with their husbands or any other men.

Death, as has already been remarked, was very much feared by the Mayas. On the death of a person, the relatives showed evident signs of great distress. By day they wept in silence, but at night they filled the town with their howls and cries of lament. In addition to this they fasted for a number of days. In the mouth of the deceased were placed grains of maize and the stone money they used, with which to buy provisions in the next world. Burials took place either in the house or just behind it, and with the body were placed a number of the private idols of the deceased, or in the case of a priest or sorcerer, his books or his medical implements. As a rule, after a death the house was deserted by its inhabitants; however, if the household was large, they plucked up courage to continue to occupy it.

The nobility were cremated, and a temple was built over the urn in which the ashes were deposited, or the ashes were placed in a hollow statue of earthenware. 
Another interesting form of disposal of the dead was practised among the nobility. Part of the body was burnt and placed in hollow wooden statuettes, which had an opening at the back of the neck. The corresponding piece of skin of the dead man was removed and stuck over the aperture. The rest of the body was interred, but the statuettes were kept in a place of honor among the household gods.

The Cocom, one of the ruling families of Yucatan at the time of the conquest, possessed a special form of preservation. The deceased's head was cut off and cooked, and all the flesh removed. The skull was then sawn in half from top to bottom. The front half was subsequently covered with wax, which was modeled to the features of the dead man. This half head was then placed in the family oratory with great reverence, and offerings were made to it on feast days and other occasions of great rejoicing, so that the soul of the deceased might lack nothing in the next world.

The eldest son succeeded his father, but the younger sons were held in great respect if their father had belonged to the nobility. If the heir was a minor, a guardian was appointed to look after the estates, and any defalcation on his part was considered a very heinous crime.

The large stone buildings of both the Old and the New Empire (Plates VI, IX and X) were undoubtedly for the most part religious buildings. The nobility probably occupied smaller stone houses, but the populace as a whole lived in thatched houses with a wooden framework. These were covered with a pent-roof, the eaves of which reached down to the ground. A wall with several doors divided the front half of the house from the rear half. The latter was the sleeping apartment. The front half was whitewashed, and often adorned with frescoes, and served as a reception room, although owing to the fact that it was open in front, it 
partook more of the nature of a veranda. The chief furniture of the inner room was supplied by the beds, which were made of wood with cotton coverings.

The common people had the task of building the houses of the nobility, and in addition had to work on the plantations of the latter. They also handed over a percentage of the bag if they went out hunting, and a share of the salt they had to fetch, often from considerable distances.

Agriculture was the chief industry, maize, cacao, and cotton being the most important crops. Each family possessed an allotment of some thirty-six square yards. Cooperation was extensively practised, families helping one another in sowing and harvesting. In addition to these town lots, any family was free to go farther afield and take up a piece of the common land. Bees were kept for their honey, and the turkey had been domesticated.

Extensive trade was carried on between the cities, and long journeys were often made with this object. Salt in many parts of Yucatan was rare, and was an important article of commerce. Bishop Landa informs us that a big trade was done with Tabasco and Uloa, salt, slaves, and cloth being paid for in cacao and stone money. There were various forms of currency, of which cacao seed was the most important, but stone disks, feathers, red shells, and copper axe-blades also circulated. Credit was given, and loans were made without usury.

The punishment for theft, if the stolen property could not be returned, was slavery. In time of famine a great deal of theft occurred, and as a result there was a large increase in the number of slaves.

Maize was the basis of the principal Maya dishes. The grain was softened by leaving it overnight to soak in a mixture of lime and water. In the morning the outer coat was sufficiently soft to be easily re- 
moved, and the kernel was then ground between millstones. In this state it could be reduced to great balls, and preserved for several months. When required, a piece was removed and mixed with water in a drinking gourd, and made an excellent beverage. Eaten, it made a delicious and nourishing dish. Another dish was obtained by compressing the ground maize, and the juice thereby exuded was curdled by heat; it was served hot the following day. It was also toasted and served with chile and cacao.

Margarine was manufactured from cacao seeds, and was used in a large number of dishes. Stews of every kind were made, composed of venison, fowl, fish, or vegetables. Bread was usually eaten freshly baked, as maize bread when stale is somewhat unappetizing.

An alcoholic beverage was made of a fermented mixture of honey and water, and also of a certain root, possibly of the yucca family, which in many parts of South America is chewed to cause fermentation in the same way that the well-known kava of Oceania was prepared.

Banquets were very frequent, and were the occasion for friendly rivalry in ostentation and hospitality. The guests to a banquet had at some future date to return the compliment, unless it happened to be a family affair, and should a guest die before he had reciprocated the hospitality shown him, the duty devolved on his heirs. A good host would spend the savings of months of hard work in entertainment. The guests sat at small tables of two or four persons, women of course being rigorously excluded. Each guest was given a roast bird, bread, and cacao to drink. After the meal the cup-bearers served the guests with the honey wine from large earthenware jars, until they were helpless, when their wives appeared on the scene and conducted them home. Each guest, too, was presented with a cloak, a small stool, and a beautiful cup. 
The Mayas, however, when drunk seem to have been a very quarrelsome lot, as we are told trouble often ensued when they arrived home in the care of their good wives. It was no uncommon occurrence for the husband to burn his house down, and brawls were frequent. Their wives also partook of carousals of their own, but apparently did not indulge to such an extent as the menfolk. Visits were invariably accompanied by an exchange of presents.

The Mayas were, like every other primitive nation, extremely fond of dancing, and nearly every festivity whether religious or social was the occasion of dancing. One of the favorite dances was performed by some eight hundred men carrying small banners. On other occasions the performers formed a circle, and two of the number danced in the centre, one of them with a bunch of reed lances in the hand; the other danced squatting, apparently in the style of the Russian folk dances, the former, with all his strength, hurled his lances at his partner, who parried them one by one with a small wooden pole. The dances were kept up from morning to night, food being brought to the dancers on the spot. Women were not admitted to these dances, and it was considered wrong for a man to dance with a woman.

The musical instruments were numerous. There were at least three varieties of drums, small ones beaten by hand, others of hollow wood beaten with a rubber-tipped gong. They gave a deep sound which was audible sometimes at a distance of six miles, and in addition turtle-shells were beaten with the palm of the hand. Flutes and whistles were made of reed or bone, and large conch-shells served as trumpets. Trumpets made of hollowed wood which had a large calabash as mouthpiece were also used. Rattles too were employed. In the Dresden Codex several of these instruments are shown in one scene. 
The most important game in Yucatan at the time of the conquest was the ball-game already referred to in the Popol Vuh. The Tlaxtli, to give the game its Mexican name, was played in a court which varied in size, but might be as much as 150 yards long and 40 yards wide, and was enclosed by high walls, so as to form the shape of two T's placed base to base. The game was played with a rubber ball, the object being to drive it through a ring placed high up on each wall half way between the opposing sides. The game could either be played like our hand-ball, hitting the ball with the gloved hand, or where skilled players were contesting the ball was hit with the hips, which were protected by a pad, and hands were not allowed. A trial of this method will soon convince the reader how difficult it must have been to get any way on the ball. The game was intimately bound up with religion, and the courts were beautifully sculptured with figures of the deities, and at Chichén Itzá a temple is attached to the court. No Tlaxtli courts have been discovered in the area of the Old Empire, and the three or four that occur in Yucatan are sculptured in Mexican style, especially the very fine one at Chichén Itzá. We can therefore safely conclude that the ball game was not played by the early Mayas, but was introduced by the Mexicans not long before the arrival of the Spaniards. This assumption is further supported by the elaborateness of the court at Chichén Itzá, which is known to have been especially under Mexican influence.

The men wore large square cotton cloaks over their shoulders, and round their waists long cumber bands of the same material about a handbreadth wide, which were twisted round several times. The ends, which were embroidered with feather work by the women, hung down in front and behind. Sandals of hemp or deer hide served as footgear. On the monuments of the Old Empire may be seen examples of very 
elaborate dress, and it would seem that in early times at any rate, important functionaries wore full length dresses. These, in many cases, exhibit very beautiful and highly complicated patterns, which indicate that a very high level of skill in textile embroidery had been reached (Plates I, IV, V). A kind of gauntlet was worn around the wrist about nine inches wide, and leglets with tassels were also worn above the knees. Nose and ear-plugs were very popular, and necklaces of worked stone or copper were also. worn. On special occasions the men painted their faces and bodies red. Tattooing was very common, and as the process involved considerable pain, any one well tattooed was greatly respected, and even made fun of his companions who had not undergone the ordeal.

Men wore their hair long. On the top of the head a round patch was burnt, so that the hair there should only grow short, but the rest of the hair was wound around the head, the tail hanging down behind. The priests seem to have invariably worn their hair matted with the blood of the sacrificial victims. Teeth filing was practised both in early and late times, and it is interesting to note that one of the attributes of the sun god was filed teeth (Fig. 3). Sometimes jade was inlaid in the teeth, and labrets (lip buttons) were common. An extraordinary variety of head-dresses existed, brilliant plumage being very favored, and for ceremonial occasions animal masks were much used (Fig. 11).

The women of the Campeche and Bakhalal areas wore a skirt, and covered their breasts with a cloth, but in the rest of Yucatan the only garment worn by the women was a kind of sack open at both sides, which formed a skirt, and was kept in position by being tightwaisted. From the waist upward they tattooed their bodies with the exception of the breasts, and wore ear ornaments and nose rings of amber. Teeth were filed 
down by an old woman with hard stone and water, and the effect was to give the teeth the appearance of being a saw. They also anointed themselves with a red preparation like their husbands, and in addition to this perfumed colored unguents were stamped on with special designs and lasted a number of days.

Women's hair was dressed in a number of different ways; some parted it in the middle, others plaited it.

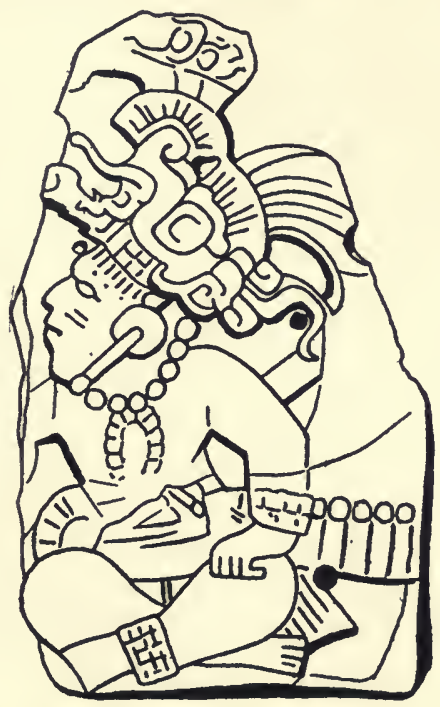

Fig. 11.

Warrior from a Maya Carving on a Shell Found at Tula.

In Field Museum (Hall 8, Case 14).

Young girls wore it in four or two plaits, and mothers were particularly careful with their daughter's hair before marriage. Cogolludo tells us that a prisoner whose guilt was not definitely proved was not acquitted, but had his long hair cut short, which was considered a great insult.

The Mayas were very superstitious, and magic played a large part in their lives. Needless to say, they believed in and interpreted their dreams. If a traveller 
feared that he might not reach his destination until after dark, he placed a stone in a tree, or plucked out his eyebrows and blew them toward the sun. These actions were believed to cause the sun to travel more slowly or even to stop, and so permit the traveller to reach his destination before dark. Eclipses of the sun and moon were very much feared, and apparently the Mayas hoped to avoid calamity by making as much noise as possible, as on such occasion they beat their tables, doors, and seats, and pinched the dogs to make them howl. The eclipse of the moon was believed to be due to its having been bitten by a species of ant, called $x u l a b$. However, as has already been shown, the priests were well aware of the time when an eclipse was to take place, but probably it suited them that the populace should be kept in ignorance.

A belief in witches was general. Among the accomplishments attributed to them was that of being able to cause flowers to open before their time, and any one who was unfortunate enough to smell a flower so treated, was driven mad. Sorcerers, on the other hand, gave exhibitions of snake charming.

A traveller stumbling against a large stone, would reverence it, and place a branch upon it, and as a preventative of tiredness he rubbed his knees with another.

During the unlucky days of Uayeb, at the end of the year, no one ventured out of doors, except in connection with the festivities that were to usher in the New Year.

Just as in Europe to-day, after some fifteen centuries of Christianity, superstition still lingers on, and in the more remote districts a belief in the bewitching powers of some feared member of the community yet exists, so too among the modern civilized Mayas with their clothes imported from London or New York and their Parisian fashions the old beliefs die hard,-magi- 
cal beliefs probably thousands of years older than the worship of Itzamna, Chac, or Kinich Ahau, but which possibly will even outlive Christianity. For just as the things we learn in our earliest youth are the things we longest remember, so the beliefs of our ancestors when the world was young are likely to be the last we shall discard. 


\section{WARFARE, ART, AND ARCHITECTURE}

The Mayas of the Late Empire were a highly warlike nation, as the Spaniards found to their cost. In fact the subjugation of the whole peninsula was not accomplished until toward the end of the seventeenth century. Even then there were one or two important tribes such as the Lacondones in the Usamacinta River area, and the Santa Cruz tribe around Bakhalal who were never properly subdued.

The armies were under a dual command. One general held the position for life and was succeeded by his son; the other who was known as Nacon held the position for three years only, and combined his duties as general with those of high priest of the army. During these three years he had to avoid all women and abstain from all meat and intoxicants. His followers, however, held him in very high esteem, and supplied him with fish and iguanos, which apparently were not considered meat.

The backbone of the army was a militia force known as Holcanes, who in peace time carried on their ordinary civil occupations, but on the outbreak of war were immediately called to the colors. They were given meagre pay by the two generals from their own purses, and should that not be sufficient, the people contributed the balance. The people too were responsible for the food supply, which the soldiers' wives cooked.

When the war was very important, the whole manhood of the nation was called to arms. On the conclusion of the war, Landa informs us, the demobilized soldiers became a thorough nuisance to their fellow townsmen, as they expected to be feted and waited upon by those that had stayed at home,-a state of affairs not unknown in modern society. 
WARFARE, ART, AND ARCHITECTURE

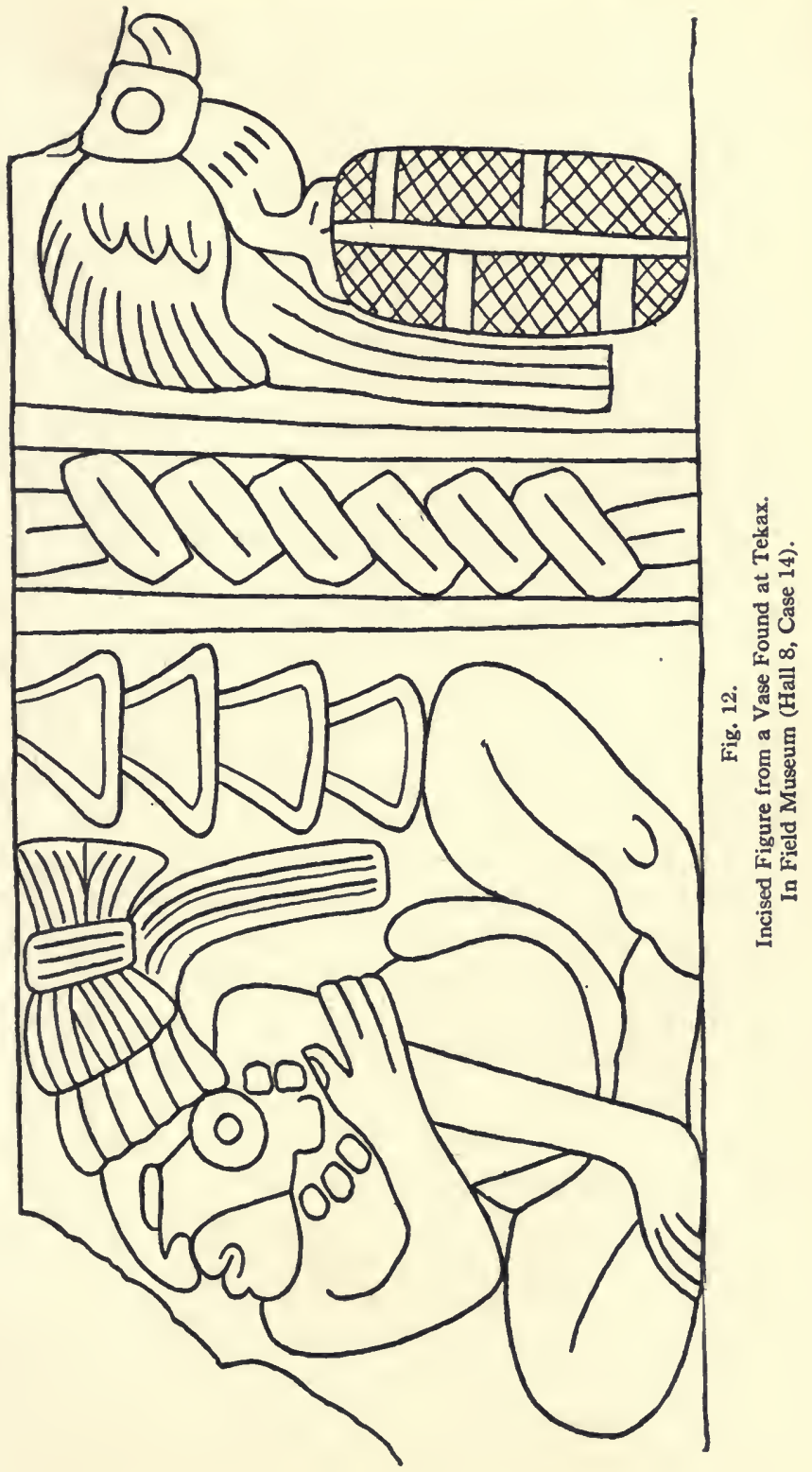


In the time of the Late Empire the soldiers were armed with bows and arrows, but there is reason to believe that these were introduced by the immigrants from Mexico, and that in the Old Empire they were unknown to the Mayas, who at that time seem to have been a peaceable nation.

The arrows were tipped with imported obsidian or fish bones. The bows were made of a very strong wood, with little curvature, and nearly as tall as a man. The arrows were made of reed, and the obsidian head was wedged into a piece of thin, hard wood, which was attached to the reed shaft. Poison was never employed. Copper axes hafted in wood were also employed, as well as short lances, and wooden swords studded with obsidian blades, which were wielded with both hands. Spear throwers are represented at Chichén Itzá. Defensive armor consisted of round shields of wickerwork with deer-hide coverings. On the monuments of the Old Empire square shields are depicted, and at Chichén Itzá Mexican frescoes show long, flexible shields.

Cotton quilts were also worn, and contained layers of salt. They reached down to the knee, and as the name used is a Mexican one, and such quilts were known in Mexico, it seems likely that they too were introduced from the north. Although cumbersome, they formed an efficient protection against spears or arrows.

Officers of rank wore a kind of wooden helmet and skins of pumas and jaguars.

Fortifications, with the exception of palisades, were unknown, and night attacks were never indulged in. War paint was, however, used to frighten the enemy, and a great deal of energy was wasted in shouting and hissing. After the enemy had been defeated, the conquerors removed the jawbones of the vanquished dead, and wore them on their arms. Impor- 
tant prisoners, who were not in any way disfigured, were offered up in sacrifice, and subsequently the body was ceremonially eaten by the captor and his friends. Prisoners of the rank and file were enslaved.

The Spanish cavalry, of course, gave a tremendous advantage to the conquistadores. An account is given of one battle, in the course of which the Indians endeavored to seize the horses by the legs. Cortez, during his march across Guatemala to Honduras, left behind him a lame horse, which was looked after by the Itzá at Peten, but probably owing to the change of diet and treatment the horse died. The Spanish friars, who visited Peten in the seventeenth century, were horrified to find that the Indians were worshipping an image of this very horse and considered it one of their most important gods.

The first horses seen by the Mayas were those used by the cavalry. Not disassociating the horses from their riders, the Mayas imagined the firing of the arquebuses of the Spaniards was a manifestation of the wrath of this strange animal. The horse was therefore considered to be able to deal out thunder, lightning, and thunderbolts that brought destruction in their path. The association of the horse with the deities of thunder and lightning was therefore a natural one. The horse was offered meat, turkeys, and floral wreaths, and not unnaturally died of hunger.

Naval warfare was apparently never of very great importance. The Mayas had large sailing-canoes reported capable of holding up to forty men. A passage in Cogolludo mentions double canoes, but there is, of course, a possibility they may have been introduced by the Spaniards, though that is hardly likely, as he calls the boat "una falca," and explains that by that is meant two canoes tied together. The crew consisted of 
fourteen Indians, and a sail was hoisted. The region where this double canoe was used was that of Bakhalal.

There were two exceptions to the general degeneracy that set in when the Mayas, leaving Guatemala, established the New Empire in Yucatan,- the sciences of warfare and architecture.

Throughout the New World the true architectural arch was unknown prior to the arrival of Columbus, and its absence seriously hampered the style, size, and beauty of all the Maya buildings. There are only two substitutes for the arch known to mankind,- - the false or corbelled arch (Plate VII and X), and constructions whose walls and pillars are sufficiently close together to enable them to be spanned by a single beam or slab of stone. The corbelled arch was well known to the Old World, and it was adopted by several of the ancient civilizations, notably at Mycenae, and even in bronzeage tombs of Ireland. The false arch may be compared to two inverted staircases, which approach close enough to be spanned by a single slab, each step of the staircase projecting slightly beyond the step below it. Unlike the true arch each brick or stone of which is self-supporting, the false arch is composed of a number of steps, whose weight has to be borne by the lower steps. To counterbalance this weight great massiveness is required on the edge of the arch; generally as much breadth of counterweight is required as the breadth of the arch, which in its turn is determined by the height of the arch; thus an arch ten feet wide will require some five feet of wall on each side, so it will be seen that a room built on these lines will contain as much wall as floor space. There was, however, no limit to the length of such a room. Holmes has remarked that in the case of the "Palacio del Gobernador" at Uxmal, a very well-known Maya building, there is an area of more than 200,000 cubic feet of solid masonry, whereas the chamber space only 
amounts to 110,000 cubic feet; and, if the substructure be taken into account, the masonry occupies forty times more space than the chamber. From these figures it can be realized what an enormous waste of energy and masonry was required to construct a Maya edifice.

The walls of Maya buildings were as a rule faced with cut stone dressed on the outside, and the cone was filled with a very strong mixture of mortar, and rubble. Windows were very rare, but in many buildings doors are very frequent and no doubt took the place of windows. In some cases they are set so closely together that the portions of wall between them are to all intents and purposes converted into pillars.

Occasionally buildings are met with of two or even three stories, but they are necessarily somewhat clumsy, and have a very heavy appearance. In many cases a mound was raised behind the building, and on that the second story was erected, giving the appearance of a two-storied house, whereas in actual fact each story was an entirely separate building.

On the top of the roof was placed in a large number of Maya cities a strange ornament known as a roof-comb, which was merely a steep and narrow false arch running nearly the length of the building, though in the cities of the New Empire it merely consists, where it occurs, of a single ornamented wall. A flying façade replaces it in some buildings. The great height of the corbelled arch gives a very high entablature, which lends itself to decoration, of which the Mayas took full advantage.

In Yucatan the decoration was much more prolific than in the Old Empire. Whereas the latter was characterized by naturalistic art, the New Empire was entirely under the influence of geometrical design (Plates VIII-X), which bears some resemblance to the Zapotec art of Mitla. Conventionalized snake 
masks are the motif of most of the Yucatan decorations.

Important buildings of both the Old and the New Empires were placed upon large mounds or pyramids, which were often of a considerable height (Plate VI). The pyramids invariably possess a stairway on one face, and in many cases there are further subsidiary stairways on the other faces. Pyramids without temples on the summit are rare, though they do occur at one or two cities. The same applies to mounds, in which case those that possess no buildings are probably burial mounds. Pyramids were constructed of earth and rubble, and were faced with dressed stone and stucco. The sides, however, were not by any means always straight, being often curved, and the corners were occasionally rounded off. The stairways were usually of considerable breadth. The House of the Dwarf at Uxmal, for example, is seventy-two feet long, but only twelve feet deep, and stands at a height of close on ninety feet. To reach it one ascends a stairway consisting of ninety steps, the width of which is no less than seventy feet. In some instances, notably at Copan and Naranjo, the balustrades and steps were carved with hieroglyphs showing the period of construction and other important dates.

In the Old Empire, however, the Mayas showed their greatest art and skill in the wonderful sculpturing of the stelæ and lintels, with which they marked the passage of time (Plates $\mathrm{I}-\mathrm{V}$ ). In early times raised at irregular intervals, quite early the custom was adopted of erecting one to commemorate the passage of each Hotun, that is a period of five years.

Dr. Spinden in "A Study of Maya Art" was the first to make a comprehensive study of the evolution of the stelæ, which enabled him to arrange them in chronological order by a close study of their style, without any reference to the actual dates they revealed. 
He has shown how the low relief hieroglyphs gradually gave way to deep relief, and how the proportions of the different parts of the bodies, carved on the faces, and often on the backs of the stone, slowly altered.

The earliest stelæ were possibly of wood; then contemporaneously with the earliest carved examples existed a large number of plain stone stelæ, which there is good reason to believe had painted on their surfaces the dates they commemorated.

A considerable number of the hieroglyphs have not yet been determined. It would not be unreasonable to conjecture that some of these may represent important historical events that took place in the period between the dedication of the previous stelæ and the erection of the next one. It is certainly true that all the hieroglyphs at present known are connected with the calendar, astronomy, or religion.

The most beautiful specimens were erected at the close of the ninth cycle, Quirigua leading the way with some amazingly beautiful and lofty stelæ, showing among other things a very high skill indeed in the transference of feather designs to stone (Plate II). Typical of this period and this city are the weird and huge masses of stone carved into the shape of monster animals, which carry dates on their sides or faces, and so merely replace the more conventional upright stelæ. In many cases altars are found situated in front of the stelæ, often bearing the same date. Sometimes the stelæ are scattered haphazard about the cities, just as public statues may be found in any square of a modern city. In other cases they have been erected on a definite spot before some staircase or temple entrance.

The Mayas, like the ancient Greeks, seem to have painted all their statuary. Despite all that can be said against such a practice, no doubt it helped to elucidate 
the often extremely complicated designs, with which the Mayas delighted in covering any bare space. The only exception to this tendency for overembroidery is supplied by some of the tablets at Palenque (Plate I). Looking at the beautiful lines of the figures thus revealed, one cannot help wishing the Maya artist had always striven after more simplicity.

The pottery finds from the Maya district are not, in comparison with the other sides of the civilization, extensive. Until more cemetery excavations have been undertaken, it will be impossible to work out a series based on chronology and locality. However, some of the examples already encountered show very great beauty, and give promise of rich discoveries yet to come, which should stimulate workers in the Maya field to greater efforts along these lines. In Crete and other countries of the Old World it is possible to date many sites by an examination of the associated pottery, but such is not the case in the Maya domain. Such pottery as has been found, naturally, varies in beauty and shape according to the original usage to which it was put. Pots that were manufactured for every-day household use are obviously roughly finished and usually undecorated. Ceremonial objects were often beautifully painted and decorated with glyphs. Slip was very frequently employed, and not uncommonly designs were engraved on it (Fig. 12). Relief ornamentation was much favored, animals and birds being often modeled.

A considerable quantity of funerary figurines have been unearthed by Dr. Gann in British Honduras, apparently of a very late period. They are, however, of a very poor quality, and are excellent examples of the marked degeneracy that set in shortly before the Spanish conquest. Figurines of the Early Empire display a marked similarity to those obtaining farther north in 
Mexico at a later stage, and probably were the originals of many of the northern examples.

Painted frescoes are necessarily rare. The climatic conditions of Central America militate against their survival. At Chichén Itzá, however, some fine examples in Toltec style exist (Plate VII), and others in a different style were discovered by Dr. Gann at Santa Rita in British Honduras. In the latter case they are found in connection with Maya calendardates, and it would seem they represent the passage of a Katun (period of twenty years) and possibly the gods who presided over each of the twenty years. This, however, can never be satisfactorily proved owing to the bad state of preservation in which they were encountered. 


\section{THE MAYA COLLECTION OF FIELD MUSEUM}

Unfortunately the Maya collection of Field Museum is not extensive, although the civilizations of Middle America, the Aztec, Toltec, and Archaic are well represented.

Down the centre of Hall 8 are a number of casts from different Maya centres both of the Old and New Empires.

The first cast is of an inscribed stele or column found at Uxmal. Although none of the inscription is translatable, several of the glyphs are recognizable.

Beyond is a cast of the Chac-mool figure from Chichén Itzá. This was excavated by $M$. Le Plongeon. The original is now in the National Museum of Mexico City. A number of these figures have been found in Chichén Itzá; they occur sporadically from Mexico to San Salvador. They are believed to represent drinking gods. The basin in the centre was probably for offerings. The name Chac-mool ("tiger") was conferred on this figure by Le Plongeon, who imagined it represented a Maya prince of that name; but although it is now well known that such is not the case, the name is still used to describe this type of statue.

Next is a cast of Altar Q from Copan. The top of this altar is covered with hieroglyphs, to read which it is necessary to face westward. All four sides of the altar are carved in bold high relief with sixteen human figures seated cross-legged. All of the priests or kings or whomever they may represent wear turbans, and have their ears and noses adorned with ornaments. All carry large breastplates of what was probably jade, many of them being in the shape of large and elaborate masks. The figures all face toward two hieroglyphs placed one below the other, on the west side,the date 6 Caban $10 \mathrm{Mol}$. This date is found very fre- 
quently at Copan and must have been of great importance. Its position in the long count is 9-16-12-5-17, and its equivalent in the Gregorian calendar is July 1st,

On the upper surface the inscription opens with the calendar round date A1.B1. The vertical columns are lettered $\mathrm{ABC}$, etc., from left to right. The horizontal columns are numbered 1, 2, 3, etc. Thus the top left-hand glyph is A1, and the bottom right-hand glyph is F6. 5 Caban 15 Yaxkin, June 22d, A.D. 738, midsummer day, the next date 8 Ahau 18 Yaxkin is 3 days later (B3A4). A6 is a distance number of 7 Uinals and 13 Kins (153 days) to be added to the last date. Actually the inscription reads 7 Uinals and 12 Kins, the Kin co-efficient consisting of two bars and two dots with a cross between. This is a mistake made by the original sculptor; the correct distance number leads to 5 Ben 11 Muan shown in C1,D1. 17 Katuns are expressed in C6, and D6 and E1, the calendar round date 6 Ahau 13 Kayab, which is the ending of the first hotun ( 5 tun period) after the beginning of Katun 17, written in the long count 9-175-0-0 (December 28th, A.D. 775). In F3 there is the glyph for the observation of the sun at the horizon. Possibly this is to call attention to the fact that the important hotun date is only a few days off the winter solstice. In ES there is another distance number of 3 Uinals and 4 Kins reaching 5 Kan 12 Uo March 2nd, 776. Here again there is a mistake: the inscription actually reads 13 Uo. Morley has suggested that possibly the sculptor got his instructions mixed, carving 12 Kins where 13 were required, and below 13 Uo where 12 was required.

The next monument is a cast of stele $\mathrm{K}$ from Quirigua. This stele is considerably smaller than the majority of stelæ from this city. Both the front and back are carved in a squat figure with a disproportionately large head. In one case the head is surmounted by a 
mask; in the other case, two masks. The belt which hangs down is very elaborate as too are the sandals. The inscription on the north side opens with the introductory sign above which is placed the hieroglyph for the planet Venus. There follows the long count date 9-18-5-0-0 3 Ahau 3 Yax, the 3 Yax being omitted, the Gregorian equivalent of this date being July 24th, A.D. 805. In $A 6$ there is a distance number of 10 Uinals and 10 Kins (210 days) which substracted from the initial series date gives the date $10 \mathrm{c} 18 \mathrm{Kayab}$, December 26th, A.D. 804. This date is found in B6 right half and $\mathrm{A} 7$ left half. The other half of A7 is occupied by a glyph which is believed to be another symbol for Venus. This date actually marks the completion of three-quarters of a Venus year, and is at the same time within four or five days of the winter solstice. The inscription on the south side is somewhat defaced; in A4, however, is repeated the date 3 Ahau 3 Yax which it will be remembered was the terminal date of the initial series.

The following cast is that of Altar G at Copan. The altar represents a double-headed feathered serpent. From the open jaws at both ends protrudes the upper half of a human figure. The lower jaws at the large end display prominently the bleached jawbone, a symbol of death. Both ends illustrate well the very elaborate treatment employed by the Mayas to depict the serpent's jaws. The upper jaw is invariably elongated out of all proportion to the rest of the body; the lower jaw is usually of normal size. The upper jaw at the east end of this monument measures no less than three feet, whereas the lower jaw reaches barely six inches in depth. The fangs and teeth are very prominent. The west head displays prominently the Venus sign. The inscription opens with the calendar round date 10 Ahau $8 \mathrm{Zac}$. This almost certainly occupied the long count position 9-18-10-0-0, and corre- 
sponded to the Gregorian date August 20th, A.D. 800 . The connection with Venus is not very clear. Possibly the fact that 10 Ahau was also the date of the inauguration of the Venus calendar almost nine hundred years earlier was the reason why this monument carries the Venus sign.

Beyond this is placed the cast of Altar $O$, also from Copan. Whereas Altar G represented a doubleheaded feathered serpent, the front of this altar is in the form of a single-headed feathered serpent. The treatment of the elongated jaw of the serpent is the same. The back of the altar shows the double-headed feathered monster this time equipped 'with legs. One end of the altar has a representation of a frog and a fish, the other end has two human figures and a fish. There is no date on this monument, but it probably dates from about the ninth century A.D.

The next cast is that of Altar U from Copan. The front (west face) is carved in the form of a grotesque face, probably that of a conventionalized snake. On each side are represented serpents in whose jaws is seated in each case a human figure. The back and top are covered with a hieroglyphic inscription. The inscription opens in the southwest corner of the top with a new year date written 2 Caban 0 Pop. This is a mistake for 3 Caban. This date corresponds to February 10th, A.D. 741. Then follow a number of other dates including at the top left-hand corner of the side the date 6 Caban $10 \mathrm{Mol}$,- the date most frequently recorded at Copan. This corresponds to July 1st, A.D. 763. The exact significance of this date can only be surmised. Possibly it marked some important political event in the history of Copan.

Beyond this is a cast of stele 1, also from Copan. The front of this stele represents a full-length figure. Above the head is an elaborate mask with the fourleaf hieroglyph symbol of the sun. On each edge of 
the front and level with the forehead are small turbaned figures. In the folded arms of the figure rests the body of a double-headed snake, from whose jaws peer forth two heads, which, judging by their filed teeth, represent the sun god. The snake's body and heads are marked prominently with the symbols of death. No flesh is shown, merely the bare spinal cord and skull. An elaborate band girdles the waist, and from the ankle bands hang naturalistic snakes.

The back of the monument is occupied by a very plain initial series. First comes the large-sized introductory glyph followed by 9 Cycles 12 Katuns 3 Tuns 14 Uinals and 0 Kins. In B5 is the day 5 Ahau. The number 5 is represented by the head variant for 5 (see Fig. 6), the Ahau sign is a not unusual variant. In A7 the glyph expresses that on this date four complete moons had passed since the last complete lunar period. The "month" glyph which should be at A8 is unfortunately obliterated, but should be 8 Uo. This date corresponds to March 22d, A.D. 676, -an important date as it is within a day or so of the spring equinox, and is at the same time the day of a new moon and the day Ahau. Both sides of the monument, moreover, are carved with inscriptions containing two or three dates of little interest to the general public.

The following monument is a cast of Altar D from Copan. Over the top is stretched a grotesque monster that appears to represent a frog. The front side is carved with a large, double-headed dragon monster. From one head protrudes a human face. The back and the remaining side are occupied by full figure glyphs; that is, the hieroglyphs instead of representing merely faces show the full bodies. The inscription opens with the calendar round date 13 Ahau $8 \mathrm{Zac}$ (?), which probably corresponds to August 29th, A.D. 764, and probably commemorates the inception of the calendar on August 31st, 97 B.C. 
The next and last cast on exhibit represents Altar $\mathrm{K}$, also from Copan. The top of this altar is plain and roughly finished,-an unusual feature; furthermore there is no decorative element. The four sides are covered with a double band of hieroglyphs, thirty-six in all. The inscription opens at the top left-hand corner of the north side of the monument with an introductory sign surmounted by the Venus sign (in the cast unfortunately obliterated) and followed by the date 9 Cycles 12 Katuns 16 Tuns 7 Uinals and 8 Kins, which brings us to the day 3 Lamat. The "day" sign does not bear much resemblance to the usual hieroglyph for Lamat (see Fig. 7), but 8 Kins must be followed by the day Lamat. On the west side is the corresponding "month" sign 16 Yax. The Gregorian equivalent is September 4th, A.D. 688, the date of an inferior conjunction of Venus with the sun, and for this reason the Venus symbol figures at the opening of the inscription. It is only now being realized what a fundamentally important part the planet Venus played in the life and ritual of the Maya priest-astronomers.

The exhibit of Maya archæology (Case 14, Hall 8) contains a number of pieces of pottery and other small objects, mostly from Chichén Itzá and other cities in northern Yucatan. The carved shell (Fig. 11) is one of the finest Maya pieces extant. The carving which represents a warrior in the best Old Empire style was found at Tula, the old capital of the Toltecs, north of Mexico City. Needless to say, this is far outside the Maya area. It is conjectured that the piece must have found its way so far north in the course of trade. A very fine jade piece was found under somewhat similar conditions in the ruins of San Juan Teotihuacan, a very important Toltec centre not far from Mexico City. Very fine pieces such as these were no doubt preserved for centuries; indeed, fine jade ornaments of the Old Empire period have been taken out of the 
sacred well at Chichén Itzá, which must have been heirlooms centuries old when they were cast into the water. The full-length clay figurine from Palenque (Fig. 10) is a very fine example of Maya modelling in clay. Although pottery heads and full-length figurines are very common at all Aztec and Toltec sites, up to the present few have been found at Maya centres.

A number of interesting objects including the beautiful, though broken, alabaster vase, the copper bells, jade and crystal beads, carved jade pieces, and several of the tripod bowls were obtained from a deep burial shaft in a temple at Chichén Itzá by Edward $\mathrm{H}$. Thompson. On cleaning the debris from the floor of the temple, the entrance to a square shaft situated in the centre of the floor was discovered. When cleared of debris, the shaft was found to reach a depth of thirty feet. The walls were lined with cut stone. At different depths were found several graves. At a depth of thirty feet there was a small square chamber. In the centre of the floor a square stone slab was found removable, and below this a flight of steps some six feet in depth led to a short sloping passage at the end of which was a pit no less than fifty-two feet deep. At the bottom of this pit, at a depth of ninety feet, were found most of these objects. No other burial of such a type has as yet been found at any other Maya site.

A number of flint implements, arrowheads, knives, etc., give a good idea of the tools used by the Mayas.

A very fine broken bowl from Tekax in northern Yucatan shows Maya incised pottery at its best. The seated figure with hand to shoulder may represent the sun god, judging by the treatment of the hair (Fig. 12).

The incised tripod bowl from Champoton (Plate $\mathrm{XI}$ ) is a very fine specimen well worthy of taking its place with the finest aboriginal pottery in America.

Two fine vases from Xkichmook and Chichén Itzá are illustrated in Plate XII. Xkichmook, which in 
Maya means "buried beauty," is the name of a site south of Xul in Central Yucatan discovered by Edward $\mathrm{H}$. Thompson, American consul in Yucatan, in 1886. The results of his investigations have been published by this Museum (Anthropological Series, Vol. II, No. 3). Of great beauty is the jade fish (Plate XIII) found also by Mr. E. H. Thompson at Chichén Itzá. The Maya civilization probably achieved its greatest cultural advances in the realms of chronology and architecture. Unfortunately neither of these subjects lends itself to exposition in a museum. A museum deals with concrete facts, with examples of the arts and crafts of people. It depends on the individual whether that people in whom he is interested yields its spirit and stepping out of its tomb of exhibition cases and scientific monographs comes to life.

J. ERIC Thompson. 


\title{
CHRONOLOGICAL TABLE OF MAYA HISTORY
}

\author{
OLD EMPIRE
}

B.C. Maya Date

Aug. 29th 97 7-12-19-17-7 Probable date of inauguration of Maya calendar.

A.D.

March 15th 162 8-6-2-4-17 The Tuxutla statuette, earliest dated Maya object.

April 11th 327 8-14-10-13-15 Earliest deciphered Stele at Uaxactun, earliest contemporaneous monument in Maya area.

633 9-10-0-0-0 Close of Early Period of Old Empire.

731 9-15-0-0-0 Close of Middle Period of Old Empire.

889 10-3-0-0-0 Close of Late Period of Old Empire

NEW EMPIRE

Marchl1st 564 9-6-10-0-0 Earliest date in Yucatan Stele I Tulum.

May 12th $\quad 613 \quad 9-9-0-0-0$

$711 \quad 9-14-0-0-0$

Earliest date at Macanxoc.

$869 \quad 10-2-10-0-0$

Itzá settle at Chichén Itzá.

$928 \quad 10-5-0-0-0$

Initial series lintel at Chichén Itzá.

$948 \quad 10-6-0-0-0$

Itzá abandon Chichén Itzá.

$968 \quad 10-7-0-0-0$

Tutul Xiu set out from Nonoual.

$987 \quad 10-8-0-0-0$

Itzá seize Champotun.

$1027 \quad 10-10-0-0-0$

Tutal Xiu discover Bakhalal.

1145 10-16-0-0-0

$1204 \quad 10-19-0-0-0$

Tutal Xiu settle at Chichén Itzá.

Chichén Itzá destroyed.

Tutul Xiu move to Champotun.

1263 11-2-0-0-0

$1461 \quad 11-12-0-0-0$

Champotun destroyed and abandoned by Itzá.

Itzá resettle Chichén Itzá. Tutul Xiu establish themselves at Uxmal. Foundation of triple alliance.

Triple alliance collapses through war. Chichén Itzá abandoned by Itzá, who move to Lake Peten. Mayapan destroyed.

1480 11-13-0-0-0

End of war.

1500 11-14-0-0-0

Pestilence.

1520 11-15-0-0-0

First Spanish pass coast of Yuca$\tan$.

1539 11-16-0-0-0 Country comes under Spanish rule 1541. 


\section{BIBLIOGRAPHICAL REFERENCES}

The following books are recommended to the general reader who may wish to obtain a more thorough knowledge of Maya civilization. Those marked with an asterisk are specially recommended as being of general interest. Numerous papers on the subject may be consulted in the numbers of the American Anthropologist, Man, and the International Congresses of Americanists.

Bowdich, C. P.-The Numeration, Calendar Systems and Astronomical Knowledge of the Mayas. Cambridge, Mass., 1910.

Brinton, D. G.-The Maya Chronicles. Library of American Aboriginal Literature, Vol. I, Philadelphia, 1882.

Cogolludo, D. L.-Historia de Yucatan. Madrid, 1688. Merida, 1868.

GaNN, T. W. F.-Mounds in Northern British Honduras. Nineteenth Report Bureau of American Ethnology, Washington, 1898.

The Maya Indians of Southern Yucatan and Northern British Honduras. Bureau of American Ethnology, Bulletin 64, Washington, 1916.

*In an Unknown Land. London (Duckworth), 1924.

*Mystery Cities. London (Duckworth), 1925.

Gordon, G. B.-Prehistoric Ruins of Copan, Honduras. Memoirs of the Peabody Museum, Vol. I, No. 1, Boston, 1895.

Researches in the Uloa Valley. Ibid., Vol. I, No. 4, Boston, 1898.

Caverns of Copan, Honduras. Ibid., Vol. I, No. 5, Boston, 1898.

The Hieroglyphic Stairway, Ruins of Copan. Ibid., Vol. I, No. 6, Boston, 1902.

Holmes, W. H.-Archaeological Studies among the Ancient Cities of Mexico. Field Museum, Anthropological Series, Vol. I, Chicago, 1895-97.

*Joyce, T. A.-Mexican Archaeology. London and New York (Lee Warner), 1914.

*Guide to the Maudslay Collection. British Museum, London, 1923.

*Landa, Diego DE.-Relacion de las cosas de Yucatan. Edited by Brasseur de Bourbourg, with commentaries and French translation. Paris, 1864.

Lothrop, S. K.-Tulum, an Archaeological Study of the East Coast of Yucatan. Carnegie Institution, Publication No. 355, 1924. 
MALER, T.-Researches in the Central Portion of the Usamacintla Valley. Memoirs of the Peabody Museum, Vol. II, Nos. 1 and 2, Cambridge, Mass., 1901 and 1903.

Explorations of the Upper Usamacintla and Adjacent Region. Ibid., Vol. IV, No. 1, 1908.

Explorations in the Department of Peten, Guatemala and Adjacent Region. Ibid., Vol. IV, Nos. 2 and 3, 1908 and 1910.

Explorations in the Department of Peten, Tikal. Ibid., Vol. V, No. 1, 1911.

* Maudslay, A. P.-Biologia-Centrali Americana. 4 vols. of text and plates. London (Dulan and Co.), 1902.

*MorLeY, S. G.-Introduction to the Study of Maya Hieroglyphs. Bureau of American Ethnology, Bulletin 57, Washington, 1915.

The Inscriptions at Copan. Carnegie Institution, Publication No. 219, Washington, 1920.

Solis AlcalA, E.-Los Ahau-Katunes del manuscrito de Mani. Merida, 1925.

*Spinden, H. J.-A Study of Maya Art. Memoirs of the Peabody Museum, Vol. VI, Cambridge, Mass., 1913.

*Ancient Civilizations of Mexico and Central America. American Museum of Natural History, Handbook Series No. 3, New York, 1922.

*Stephens, J. L.-Central America, Chiapas and Yucatan. 2 vols. New York, 1841. 1843.

*Incidents of Travel in Yucatan. 2 vols. New York,

Thompson, J. ERIC.-A Correlation of Maya and European Calendars. Field Museum, Anthropological Series, Vol. XVII, No. 1, 1927.

Tozzer, A, M.-A Comparative Study of the Maya and Lacondones. New York, 1907.

VILIAGUTIERRE Y SOTOMAYOR.-Historia de la conquista de la provincia del Itza. Madrid, 1701. 


\section{INDEX}

Abstinence, 62, 70, 74, 84

Adobe, 12

Adultery, 68, 73

Agriculture, 2, 4, 13, 14, 19, 21, 25,76

Aguilar Geronimo de, 22

Ahau Kan Mai, 60

Ahau Kin Mai, 60

Ah Puch, 32

Alabaster, 100

Alcoholic beverage, 68, 72, 77

Alliance, triple, 17

Allotments, 76

Altars, 62, 94, 96, 97, 98, 99

Amber, 80

Arch, 88, 89

Archaics, 5 et seq.

Architecture, 16, 17, 19, 75, 88 et seq.

Armor, 86

Arrows, 20, 62, 86

Asia, 2

Astronomy, 10, 11, 58, 60

Atitlan, lake, 39

Atlantean figures, 19

Avoidance of Women, 74, 77, 78, 84

Axe-blades of copper, 76, 86

Azcapotzalco, 4, 5, 6

Aztecs, 5, 21, 36, 61, 63, 100

Bakhalal, 16, 22, 80, 84, 88

Ball Game, see Tlaxtli

Banquets, 77

Baptisms, 68, 72

Beards, 30, 51, 71

Beds, 76

Bee-keeping, 44, 76

Bells, 33, 100

Bleeding, 61, 64, 65

Blow-gun, 41

Bolon Zacab, 65

Bones, 2, 63, 64, 72, 78, 86
Bow, 20, 62, 86

Brawls, 78

Brazil, 3

Breast-plates, 94

British, Honduras, 92, 93

Buffoonery, 67

Buildings, civil, 12, 75; decoration of, 17,19 ; religious, $19,75,88$, 89

Burial, 63, 74, 75, 100

Cabrakan, 41, 42

Cacao, 76, 77, 80

Calabash, 65, 78

Calendar, 10, 46 et seq., 60

Campeche, 19, 61

Cannibalism, ceremonial, 22, 63, 87

Canoes'; 87

Carousals, 66, 68, 74, 77, 78

Cenote, 15, 18, 63

Chac, 18, 25, 83

Chacmool, 94

Chacs, 27, 32, 61, 63, 67, 68, 72

Chac Xib Chac, 18

Chakanputun, see Champotun

Champotun, 16, 100

Chastity, 74

Chilan, 60, 61

Chilan Balaam, 14

Children, 67, 71, 74

Chile, 3

Chili, 77

Chichén Itzá, $15,16,17,18,19,58$, $61,63,79,84,94,99,100,101$

Chronicles, see Chilan Balaam

Cities of Old Empire abandoned, 12

Cleanliness, 72

Clothes, 11, 61, 66, 67, 72, 77, 79, 80

Cocom, 17, 18, 20, 75

Codices, 16, 24, 34, 66, 74, 78

Cogolludo Diego Lopez, 24, 81, 87 
Colombia, 6

Colonnades, 18, 19

Confession, 68

Cooperation, 76

Copal, see incense

Copan, 10, 11, 32, 58, 90, 94, 96, $97,98,99$

Copper, 3, 80, 84, 100; necklaces of, 80

Correlation, 9

Cortez, 9, 22, 87

Costa Rica, 64

Cotton, 66, 76, 79, 86

Creation myths, 40 et seq.

Cremation, 74

Crystal, 100

Currency, 74, 76

Dancing, 33, 62, 66, 68, 78

Death, 33, 35, 44, 47, 51, 74, 96

Deer, 21

Deformation of heads, 71

Desertion, 73

Divination, 81

Divorce, 73

Dog, 65, 66, 68

Door Portals, 19

Dreams, 81

Drums, 6, 66, 78

Drunkenness, see carousals

Dualism of army, 84 ; religious, 84

Ear-plugs, 80, 94

Eclipses, 82

Ecuador, 6

Education, 60, 67, 74

Eecatl, 27, 29

Exclusion of Women, see Avoidance

Façade, 16, 89

Famine, 21

Fasting, 62, 68, 70, 74, 84

Featherwork, 66, 67, 72, 76, 79, 80

Feathered Serpent, 17, 18, 19, 25, $27,29,40,96,97$
Figurines, 5, 6, 92, 100

Fire, dance, 66 ; discovery of, 45 ; new, 67

Filed teeth, 51, 80, 98

Fish, sacrificed, 64, 65; jade, 101

Flood myth, 40

Flutes, 78

Food, 13, 76, 77, 78, 84

Förstemann, 27

Fortifications, 86

Frescoes, 24, 75, 84, 93

Fruit-trees, 21, 41

Furniture, 43, 72, 76, 77

Future life, 33

Gann, Dr. T., 92, 93

Gauntlets, 80

Generalship, 61

Geological conditions, 5, 15

God, of death, $32,35,51$; of drinking, 94 ; of earthquakes, 41 ; of human sacrifice, 34 ; of maize, 32,67 ; of polar star, 30 ; of rain, $19,24,25$; of sky, $29,30,64$; of sun, $30,35,37,47,51,64,80$, $83,98,100$; of thunder, 25,27 , 29,45 ; of wind, 27,40

Goddess, 34, 35

Gold, 18, 41, 64

Goodman, 9

Guardian of children, 75

Guerrero, 22

Gukanatz, 40

Haab, 55

Hacavitz, 44

Hair, 80, 81, 82, 100

Heads, broad, 3; deformation of, 71 ; long, 3

Helmet, 86

Hemp, 79

Hide, 79,86

Holcanes, 84

Holmes, Dr. W. H., 88

Honey, 76, 77

Honey wine, see alcoholic beverage

Horse deity, 87 
Horses, first seen by Mayas, 87

Hotun, 90, 95

Houses, 12, 75; deserted on death, 74

Huaxtec, 9, 10

Huitzilopochtli, 36

Human sacrifice, $18,22,34,45,61$, 62,6

Hunabku, 40

Hunahau, 34

Hunahpu, 40, 41, 42, 43, 44

Hun Batz, 43

Hun Chuen, 43

Hunhunapu, 42

Hunnac Ceel, 18

Hurakan, 40, 44

Hurricane, 21

Incense, $64,65,67,68$

Inheritance, 77

Inquisition, 22

Insult, hair cut as, 81

Itza, 16, 18, 19, 20, 87

Itzamal, 30

Itzamna, 30, 37, 40, 64, 67, 83

Itzamna Kauil, 65

Iztab, 34

Jade, 9, 18, 64, 80, 94, 99, 100, 101

Jadeite, see Jade

Jawbones of dead removed, 86

Jimenez, 39

Joyce T. A., 25, 35

Kakchiquel, 39

Kan-U-Uayeb, 65

Kinich Ahau, 30, 47, 64, 83

Knife, stone, 62, 63

Kuculan, 17, 19, 25, 29, 37, 40, 67

Labrets, 80

Lacondones, 70, 84

Lances, 78

Landa, Bishop Diego de, 19, 23, $24,30,32,39,63,64,71,76,84$ Language, $9,15,16,47,49$
League of Mayapan, 17

Leglets, 80

Le Plongeon Augustin, 94

Lime, 76

Lintels, 90

Loans, 76

Magic, 2, 25, 41, 43, 44, 68

Maize, 3, 9, 13, 14, 32, 44, 64, 65, $72,74,76,77,81$

Mani, 67

Maoris, 37

Margerine, 77

Marriage, 73, 81

Mars, 68

Masks, $27,80,90,94,96,97$

Match-makers, 73

Mayapan, 17, 18, 19, 20, 66

Medicine, 60, 74

Menché, 10

Mercenaries, 61, 84

Mercury, 58

Mexicans, 12, 18, 19, 61, 63, 79, 86

Mexico City, 4, 5, 99

Militia, 84

Mithra, 36

Mitla, 87

Mitnal, 34

Money, see Currency

Monkeys, 32, 40, 43

Monotheism, 38

Monster, two-headed, 35, 97, 98

Montezuma, 9

Moon, 30, 44, 57, 98

Morley, Dr. S. G., 9, 95

Mortar, 89

Mourning, 74

Museum, British, 10; National, of Mexico, 94; of Basle, 10

Mythology, 40 et seq.

Nacon, 60, 66, 68, 84

Nahua, 18, 20, 27, 29, 61

Naranjo, 11, 15, 57, 96

Naval warfare, 87

New Fire, 67 
New Year ceremonies, 64 et seq., 82

Nose ornaments, 80,94

Obsidian, 86

Ointment, 62, 67, 81

Old Women, dance of, 81

Ordeals, 42 et seq.

Owl, 33, 47

Pacific, 3, 17

Paint, 6, 10, 62, 67, 86, 91, 92

Palenque, 10, 11, 92, 100

Palisades, 86

Panuco River, 9

Pepper, 70, 74

Perfume, 72, 81

Peten, 10, 20, 87

Phoneticism, 47, 49

Piedras Negras, 11, 51, 61

Plague, 21

Pleiades, 42

Plumed serpent, 17, 18, 19, 25, 27, 29,40

Poison, 42, 86

Polar Star, 30

Polygamy, 73

Popol Vuh, 39 et seq.

Potato, 3

Pottery, 2, 4, 5, 6, 44, 92, 99, 100

Presents, 73, 77, 78

Priesthood, 60

Prisoners, enslaved, 87; sacrificed, 61,63

Prophecy, 60; of arrival of Spaniards, 21

Puebla, 18

Punishment, 73, 74, 76, 81

Purification, 72

Pyramids, 11, 90

Quarternary Age, 2

Quen Santo, 14, 39

Quetzalcoatl, 18, 27, 58

Quiche, 39, 40, 45, 65
Quilts, 86

Quirigua, 11, 91, 94, 95

Rattles, 78

Rattlesnake, 18

Rayfish, 65

Renaissance, Maya, 16

Robbery, 68, 76

Roof, flat, 19

Roof-comb, 89

Rubber, 79

Rubble, 89

Sacraments, 60

Sacrifice, 60 et seq.; human, 18, 22, $34,45,61,62,65,66,80,86$

Sail, 88

Sailing-canoes, 87

Saint Thomas, 68

Salt, 70, 76, 86

Sandals, 45, 79, 96

San Salvador, 94

Santa Cruz, 84

Santa Rita, 93

Saturn, 58

Schellhas, Dr. Paul, 24, 30, 32

Sculpture, 12, 16, 19, 32, 39, 71, 80, $90,91,92,94$ et seq.

Shells, 76, 99 ; conch, used as trumpets, 78

Shields, 84

Siberia, 3

Sierra Madre Mountains, 14

Skins, 2, 84

Skirts, 80

Skull, deformation of, 71 ; treated after death, 75

Slaves, bought for sacrifice, 62

Slavery, 76,87

Smoking, 73

Snake charming, 82

Snakes, 25; two-headed, 35, 96, 97, 98

Soil, exhaustion of, 14

Soldiers, 18, 20

Sorcerers, 41, 67, 74 
Spear throwers, 84

Spinden, Dr. H. J., 90

Squashes, 3

Squinting, 71

Stairways, 11, 19, 90

Stools, 72, 77

Stratigraphy, 4

Stelæ, 10, 11, 32, 90, 91, 94

Stilts, 66

Stucco, 16, 90

Succession, 75

Suicide, 22, 34

Superstition, 81,82

Tabasco, 61, 76

Tables, 77

Tattoo, 6, 71, 80

Tayasal, 20

Tecpanec, 5

Teeth, filing of, $51,80,98$; inlaying of, with jade, 80

Tekax, 100

Teotihuacan, 5, 99

Texcoco, lake, 5

Textiles, 6,80

Theft, 68, 76

Thompson, Edward H., 100, 101

Tikal, 10, 11, 12

Tlaloc, 25, 29, 35

Tlalocs, 27

Tlaxtli, $19,42,43,44,79$

Tohil, 45

Toldeo, 24

Toltec, 18, 93, 99

Tonalamatl, 53,55

Tonatiuh, 35

Totonac, 9

Trade, 76

Travel, $63,76,78$

Trophies, 63,86

Trumpets, 78

Tula, 99

Tulum, 15

Tunculuchhu, 47

Turbans, 94, 97, 98

Turkey, domesticated, 76 ; sacrificed, 65,87
Tuxtla, San Andres, 9, 10

Twins, activities of, 43 et seq.; become sun and moon, 44

Tzolkin, 53

Uaxactun, 9, 10, 11, 58

Uloa Valley, 76

Usamacinta River, 84

Uxmal, 17, 88, 90, 94

Veiled Majesty, 45

Venezuela, 6

Venison, 65

Venus, 58, 96, 97, 99

Vera Cruz, 9, 18

Vukub Caki, 40, 41, 42

Vukub Hunapu, 42

Warfare, $12,17,18,20,34,61,84$ et seq.

Warriors, 34, 63, 68

Whistles, 78

Widows, 73

Widowers, 73

Wine, honey, 68, 72, 77

Witches, 82

Wood carving, 19, 12

Wooden men, 40

Wooden statuettes, 75

Women, adultery of, 73; attend husbands, 77; avoidance of, 74, $77,78,84$; camp followers, 84 ; dress of, 78,80 ; education of, 74 ; hair of, 81 ; jealous, 74; moral, 74 ; ointment of, 81 ; old, 66,72 , 81 ; orgies of, 74 ; sacrificed, 63 ; tattoo of, 80

Xbalanque, $41,42,43$

Xibalba, 42, 43

Xipe, 34

Xiu, 16

Xkichmook, 100

Xmukane, 40

Xpiyakok, 40

Xul, 101

Xulab, 82 
Yaxchilan, 10

Year bearers, 55, 64

Yucatan, settlement of, 15

Yucca, 77

Yum Kaax, 32
Zapotec, 89

Zero, 46

Zilil, 72

Zipacna, 41, 42

Zuyua, 15, 16, 47, 49

\section{THE LIBRARY OF THE} DEC 191927

UNIVERSITY OF ILLiNOIS

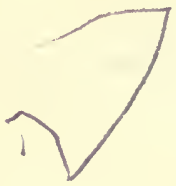




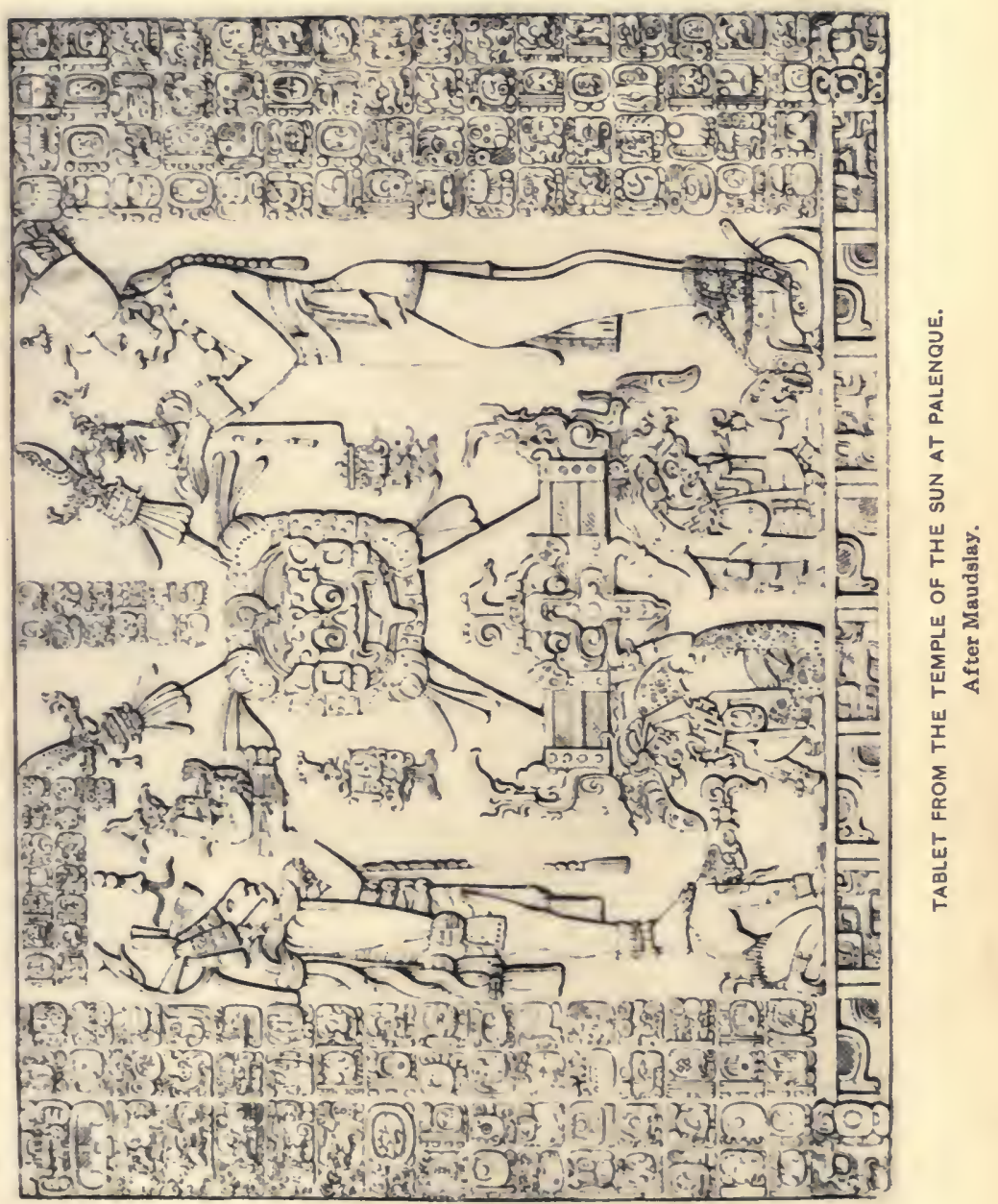


THE LIBRARY

OF THE

UNIVERSITY OF ILLWWOIS 


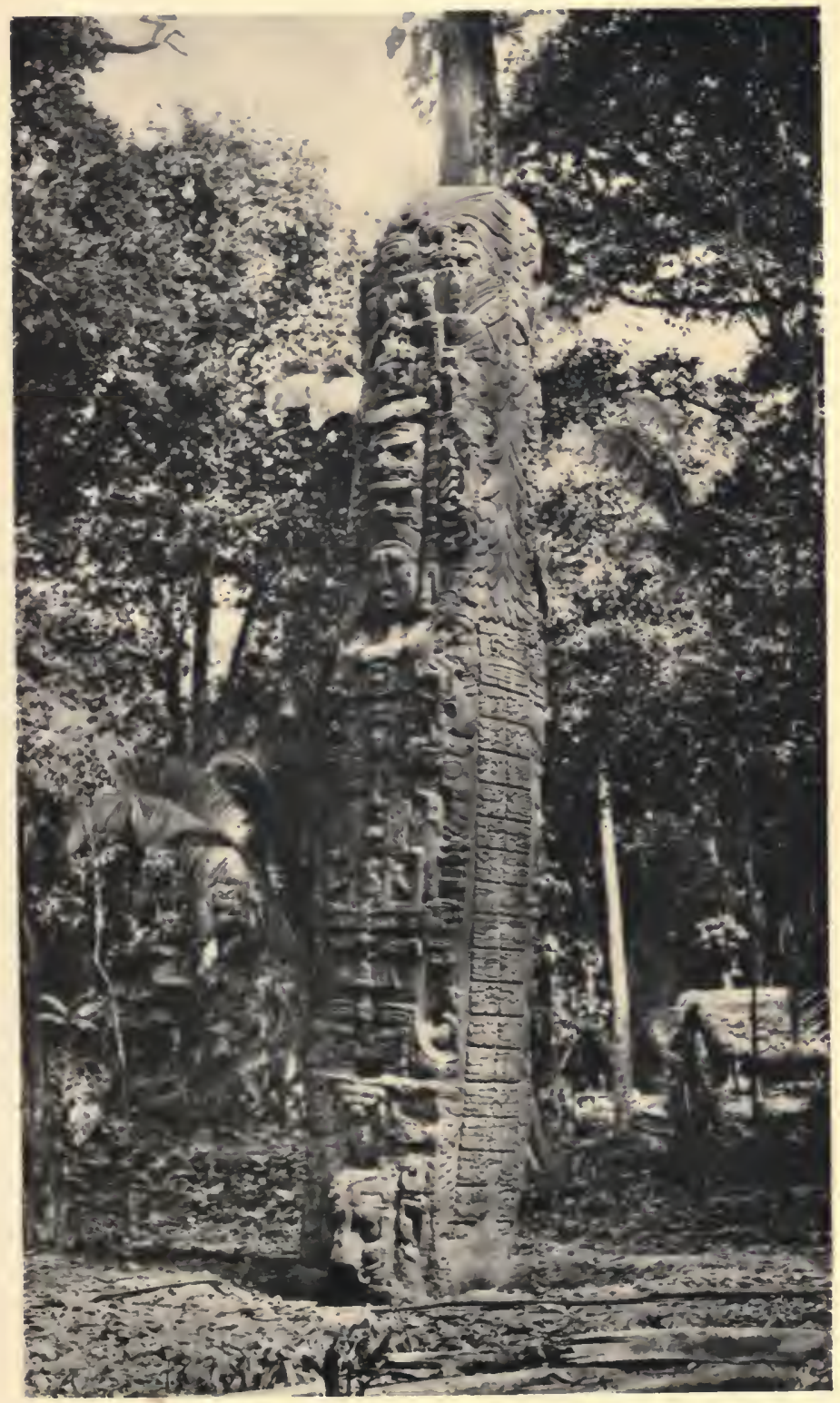

STELE AT QUIRIGUA.

A superb example of Maya art. Helght 35 feet. 
THE LIBPARY

OF INE

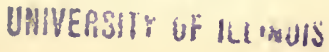




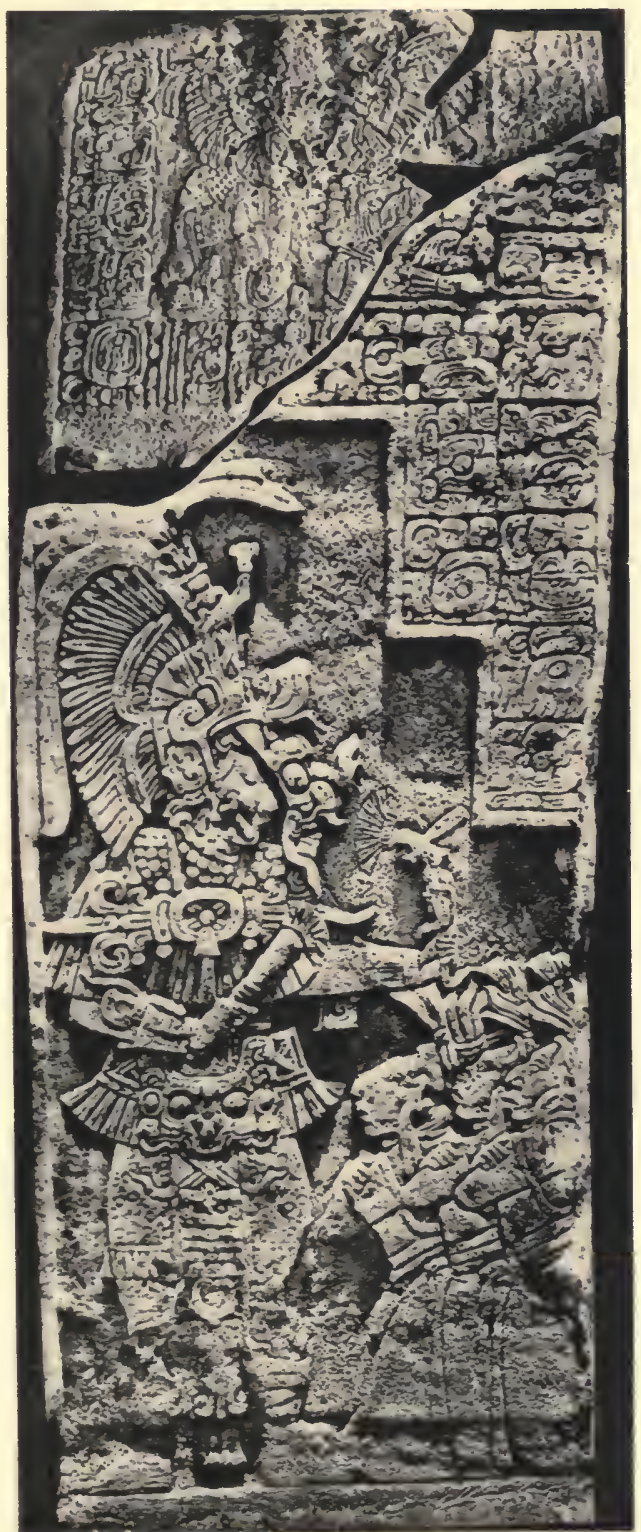

STELE 11 AT YAXCHILAN (Menché).

Kneeling figures with crossed arms before a priest wearing the mask of the sun god. 
THE LIBRAN

OF IHE

UWIVERSTT' UF 1 


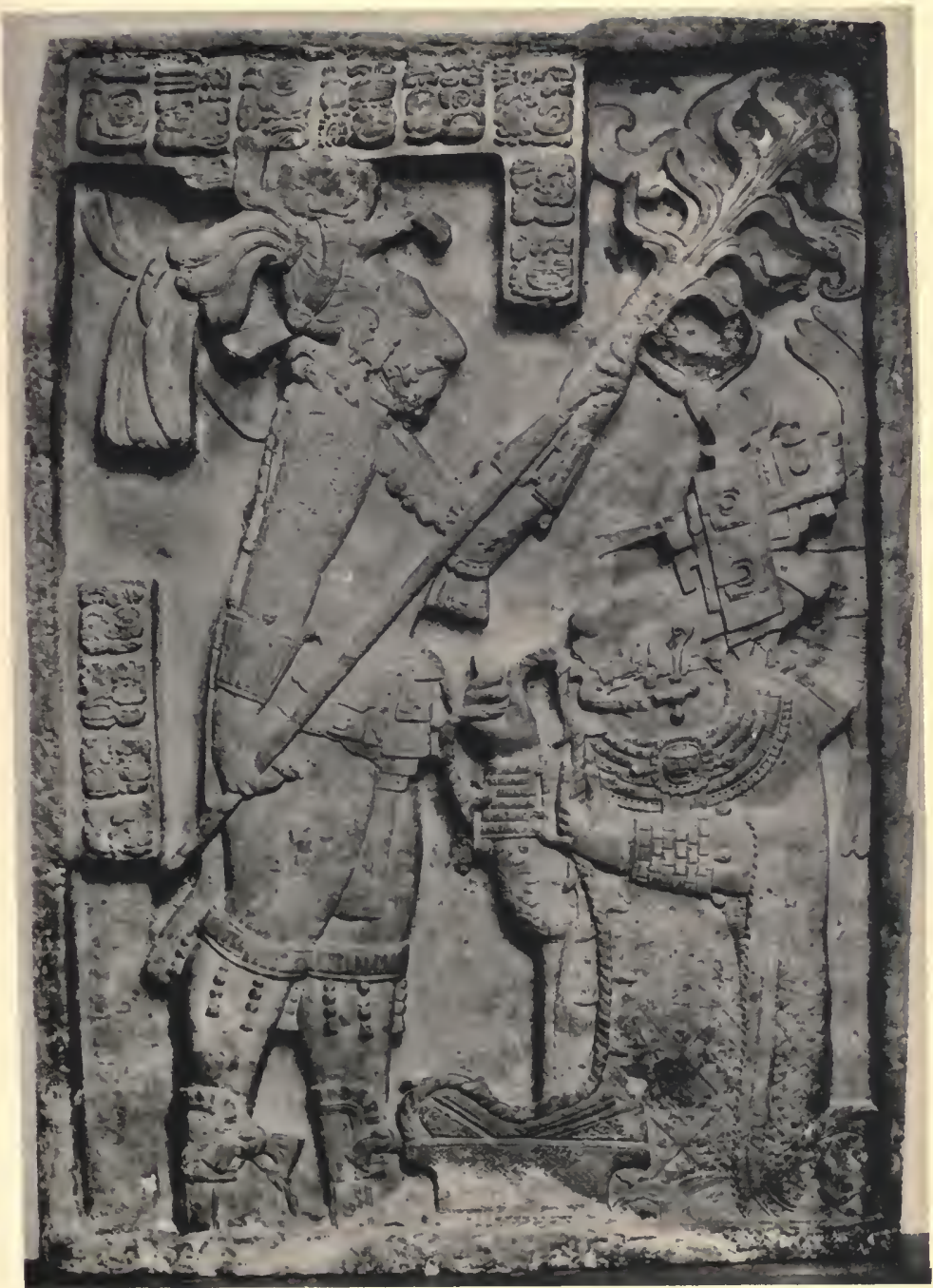

LINTEL 24 AT YAXCHILAN (Menché).

The kneeling penitent is engaged in making a blood sacrifice by passing a knotted cord with thorns through his tongue. 


\section{THE LIBRARY}

OF IHE

UNIVERSITY OF ILI WUIS 


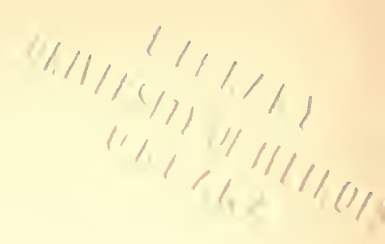

LEAFLET 25

PLATE V.

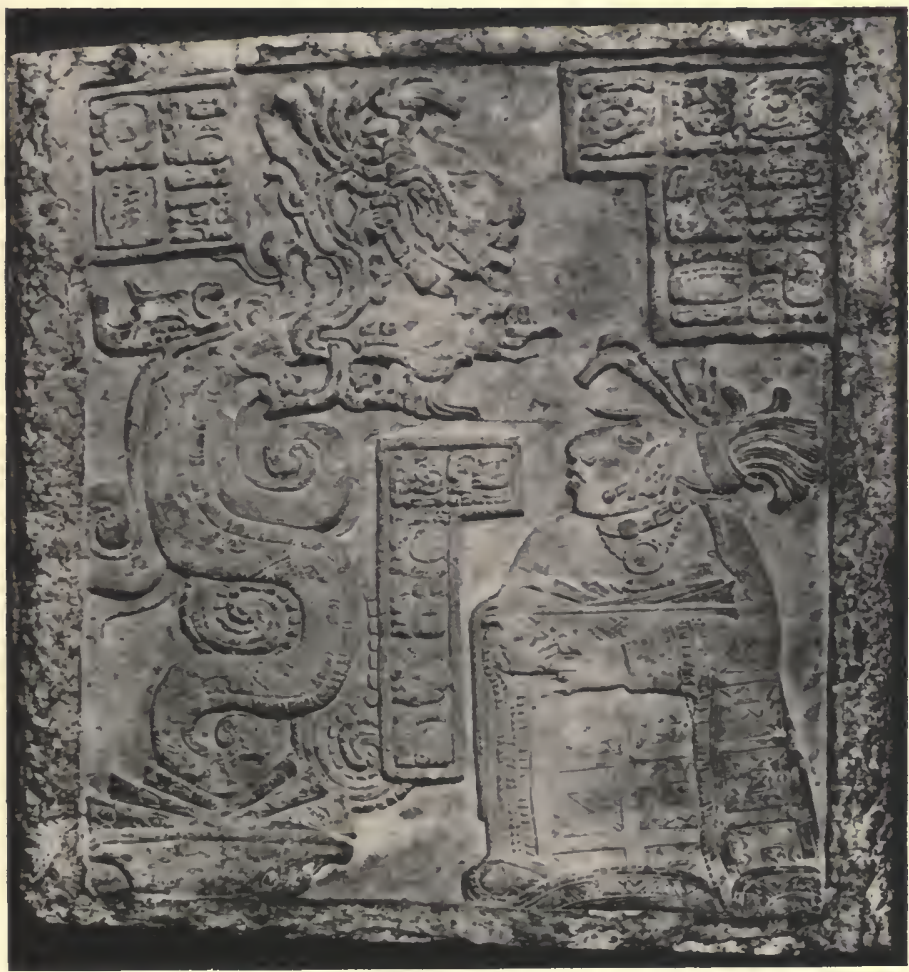

LINTEL 15 AT YAXCHILAN (Menché).

A richly garbed personage kneels before a personification of the snake god. In his arms he holds a basket.

After Maudslay. 


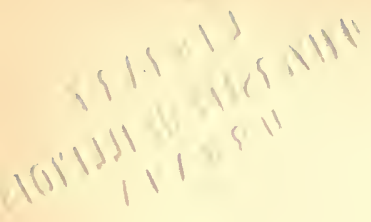

THE LIBRARY

OF IHE

UWIVERSITY OF ILITinuls 


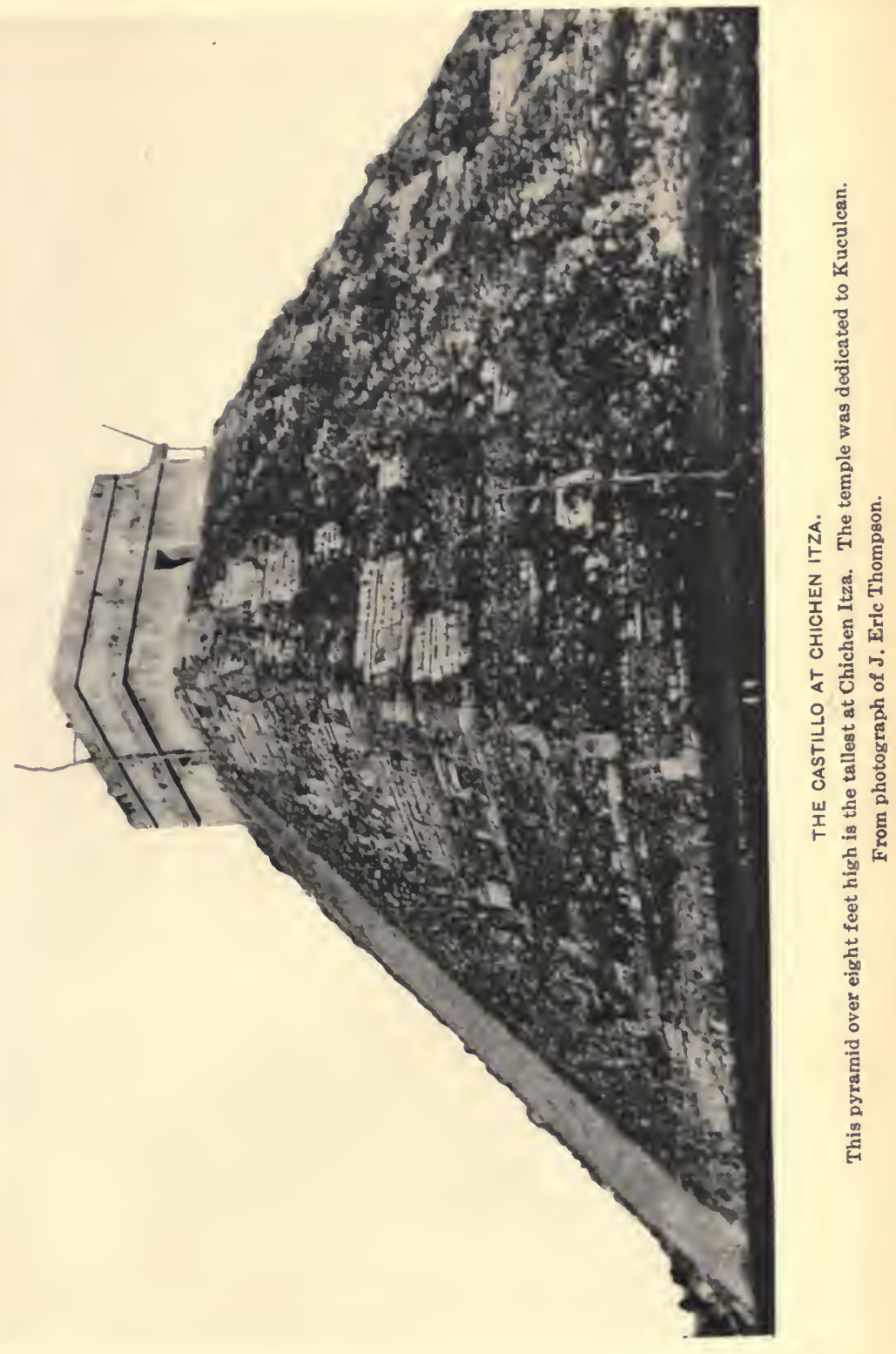




\section{THE LIBRARY}

\section{OF THE}

UWIVERSITY OF ILI HWW 


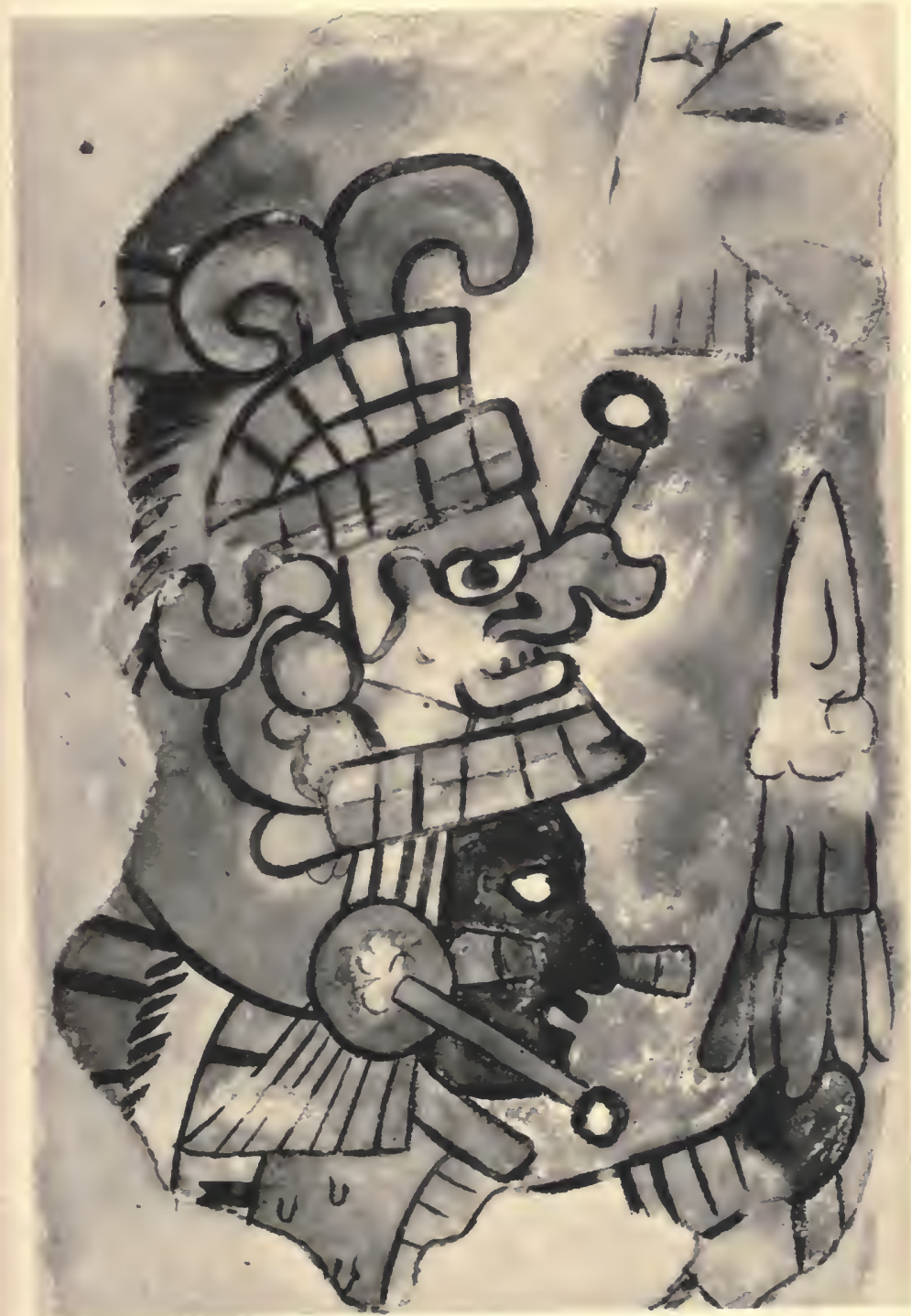

A WARRIOR FROM A FRESCO AT CHICHEN ITZA.

The warrior wears the mask of god $B$. In his hand he holds a spear.

After a water-color by Mrs. A. Morris. 
THE LIBRABY

OF THE

UHIVERSITY OF UI : 


\section{THE LIBRARY}

$$
\text { of } 1 \text { He }
$$

UAIVERSTTY UA : 


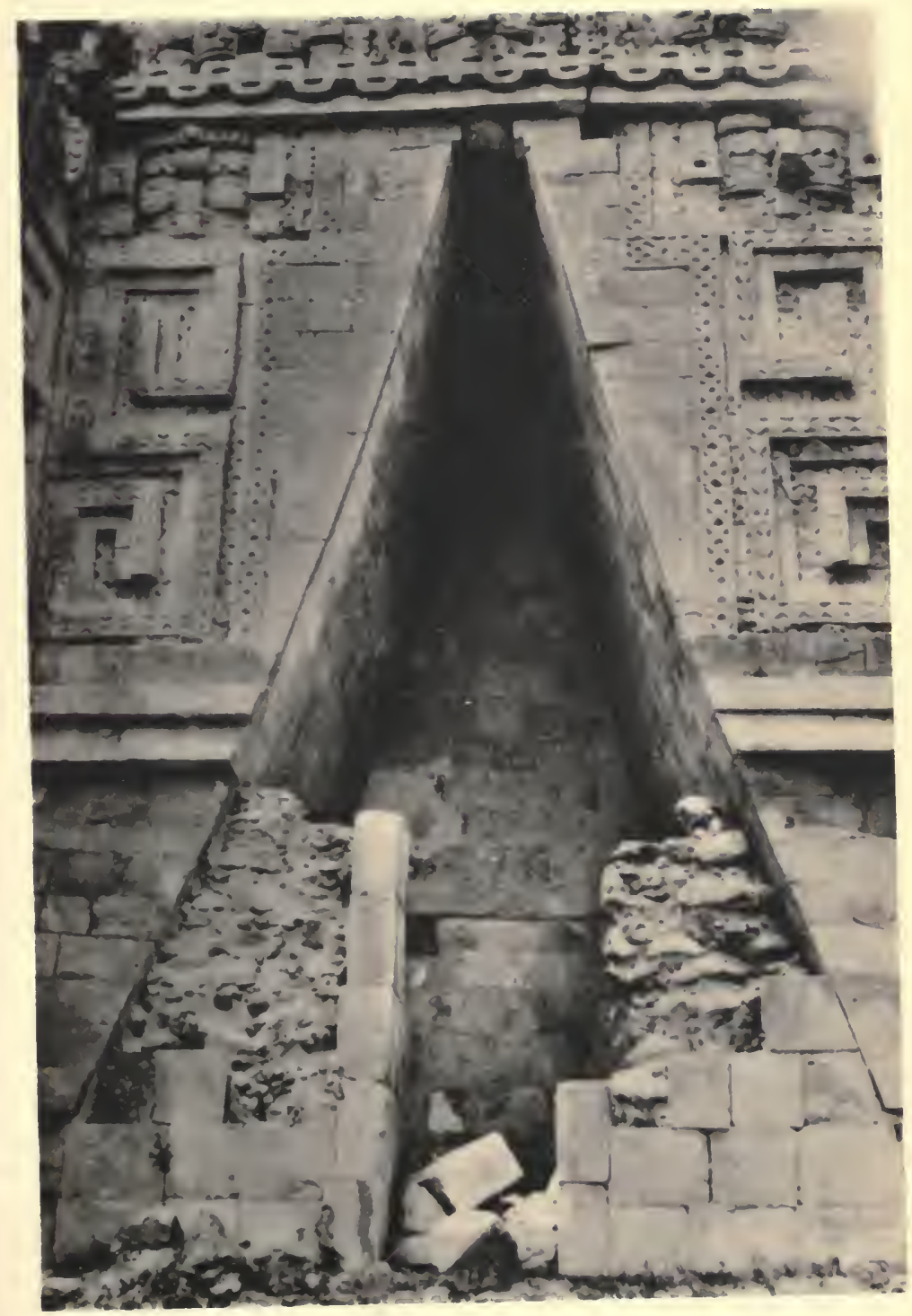

A SECTION OF THE FAÇADE OF THE GOVERNOR'S PALACE, UXMAL.

Showing the rich geometrical decorations and Maya vaulting.

From photograph of J. Eric Thompson. 



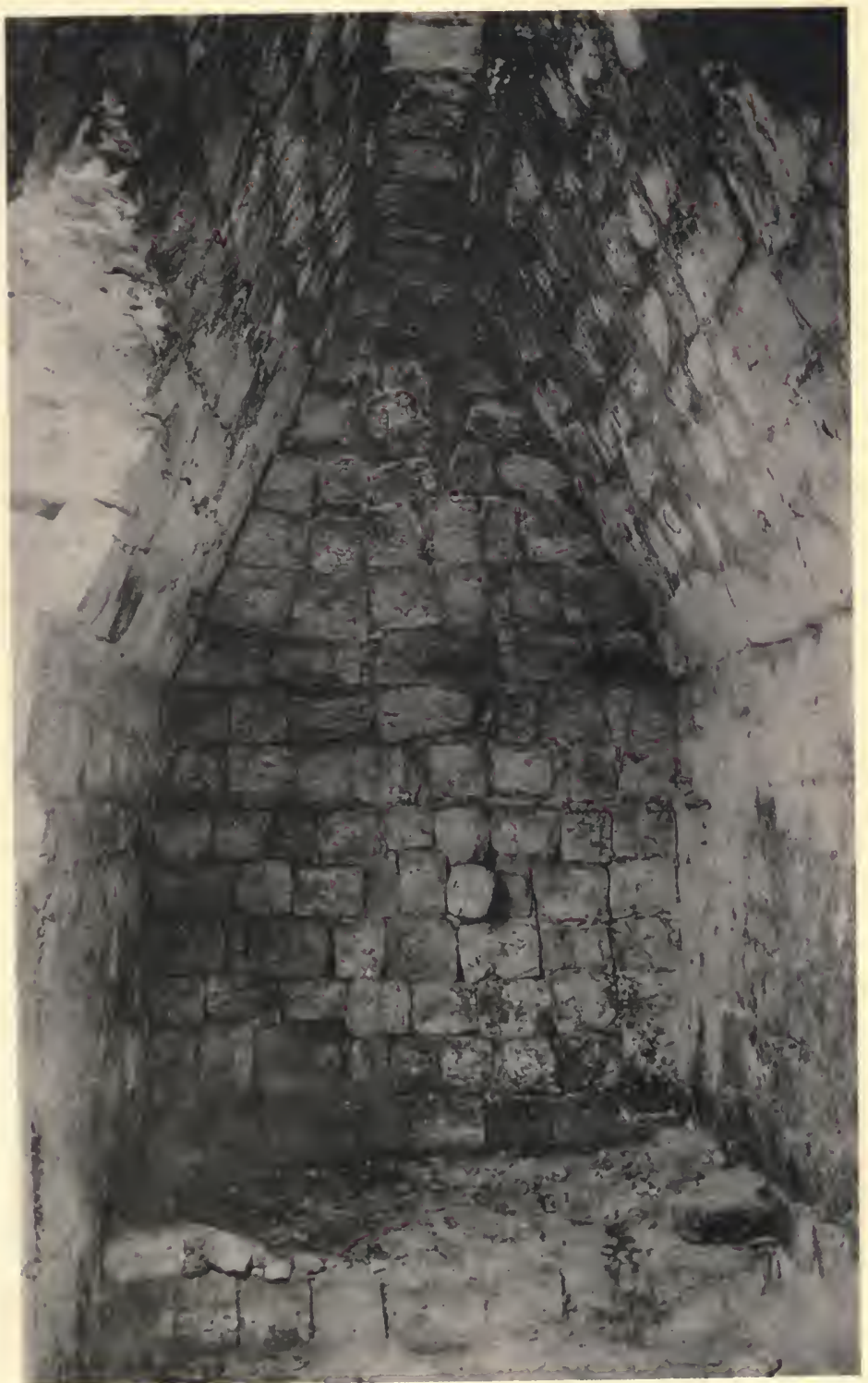

MAYA VAULTED CHAMBER, CHICHEN ITZA.

Courtesy of Carnegie Institution, Washington D. C. 
THE LIBRARY

OF THE

UHIVERSITY OF ILLIRUIS 


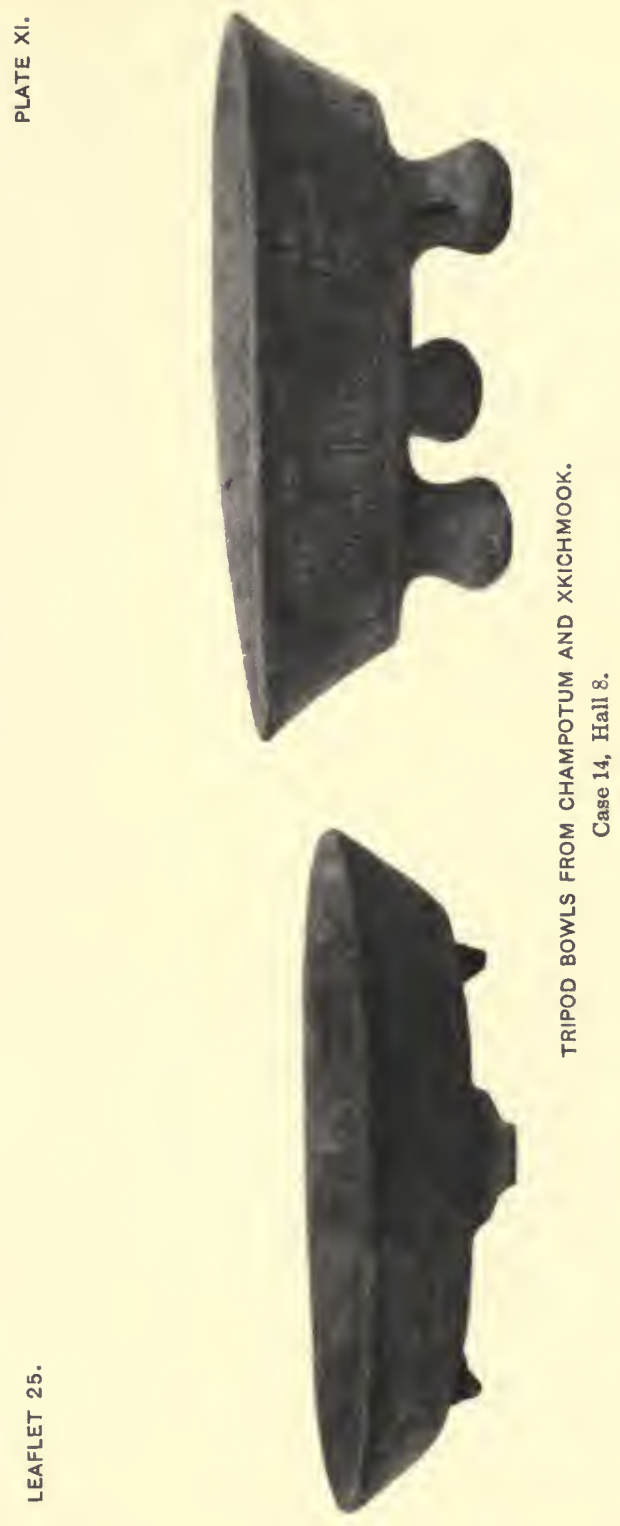




\section{THE LIBRARY}

$$
\text { OF IHE }
$$

UHIVERSTY UF 
$\dot{\bar{x}}$
$w$
$w$
$\frac{5}{a}$

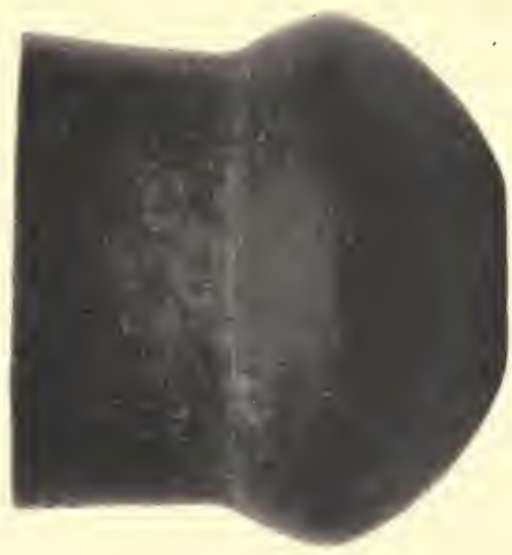

$\frac{y}{0}$
0
$\frac{0}{T}$
$\frac{1}{x}$
$\frac{y}{x}$

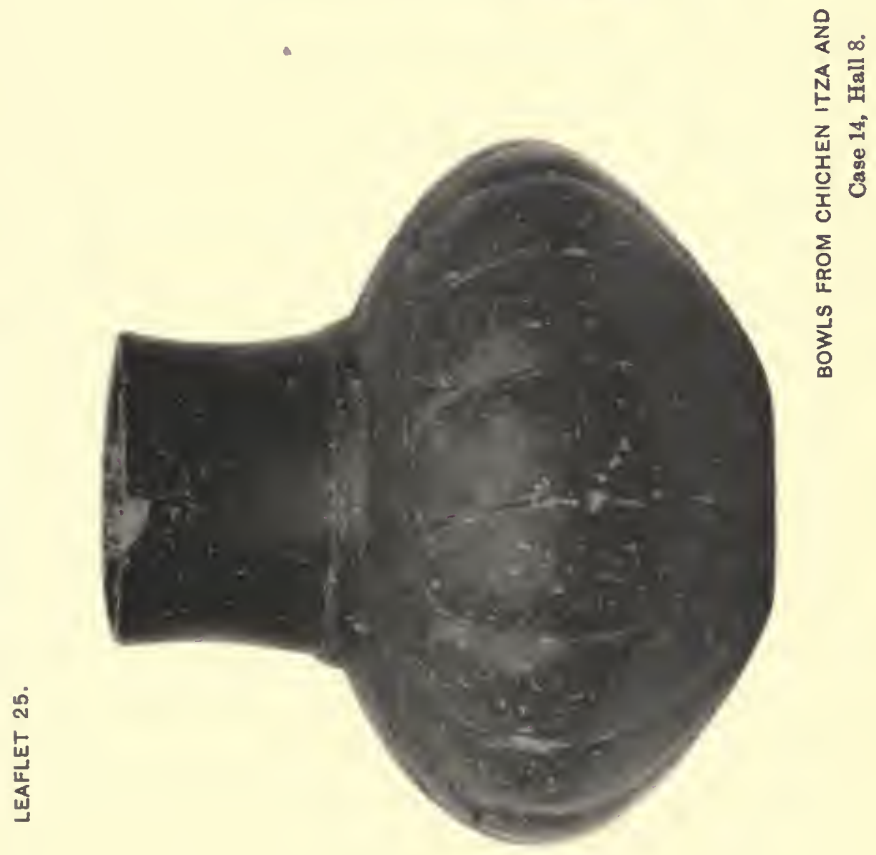


THE IIBRARY

of IHE

UNIVERSITY OF ILLINUIS 

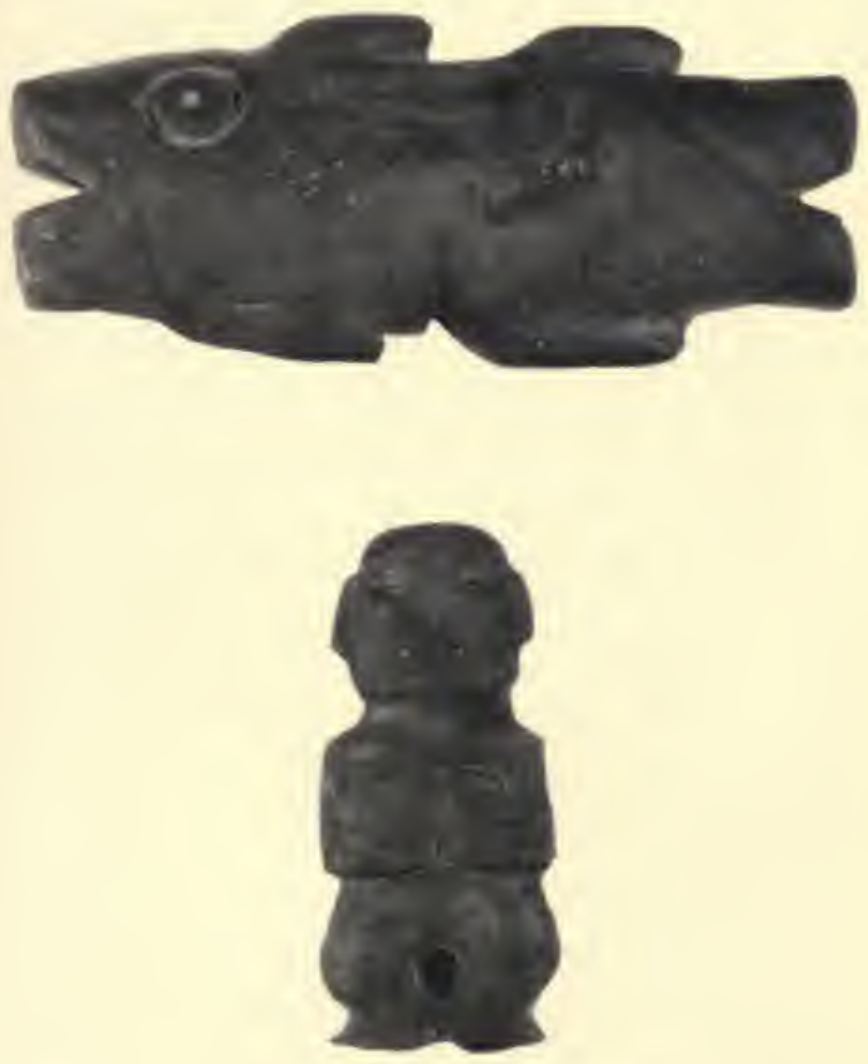

JADE WORK.

A carved fish and a small figurine from Chichen Itza.

Case 14, Hall 8. 


\section{THE LIBRARY}

OF THE

UWIYERSITY OF ILLLUONS 


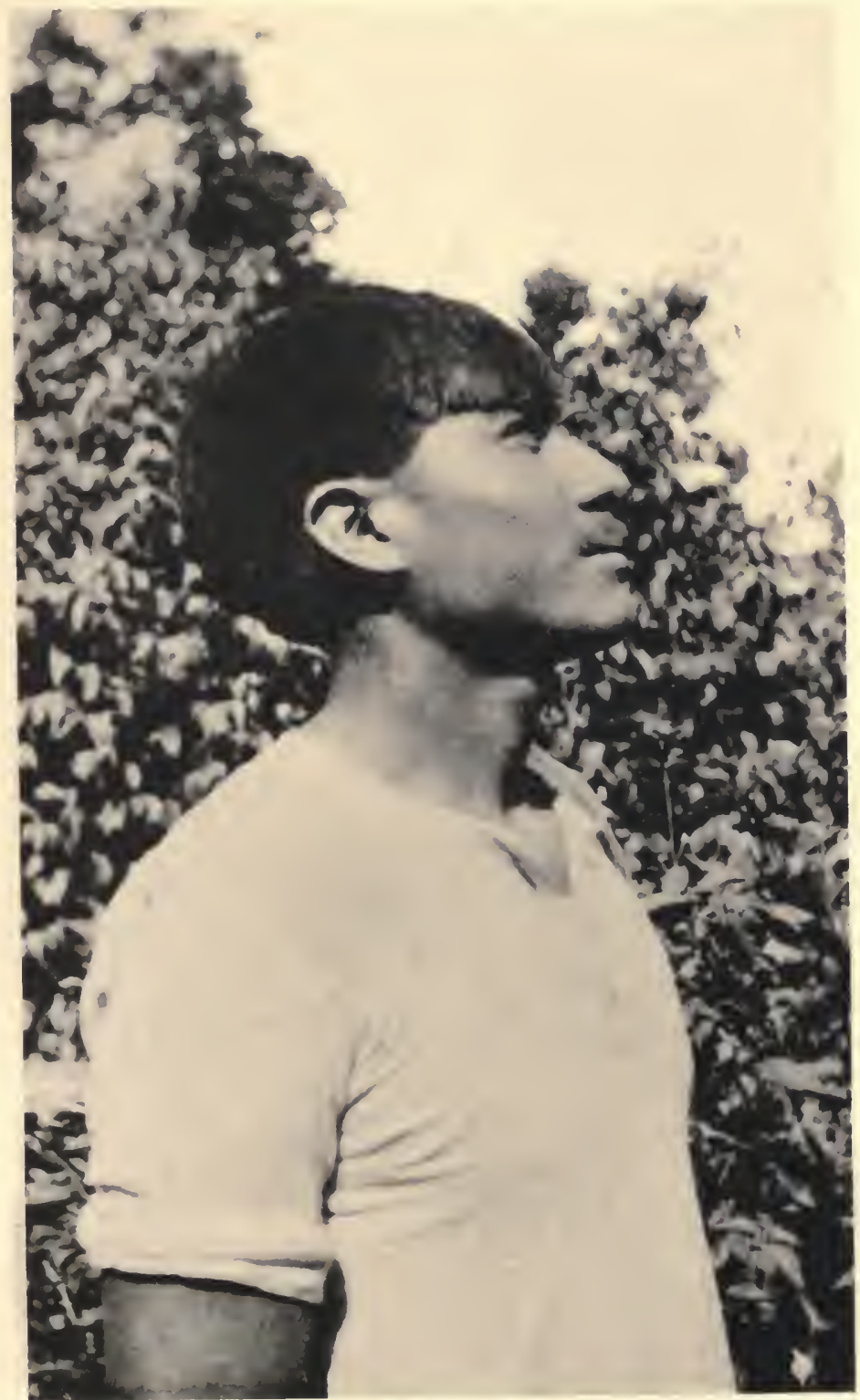

MODERN MAYA IN PROFILE.

From photograph of J. Eric Thompson. 
THE IIORARY

THE IIRRAN

OF IHE

UIIVERSITY OF ILLImUi. 



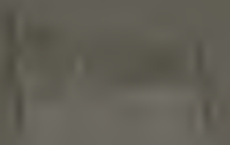



(1)

.

1

(1)

1
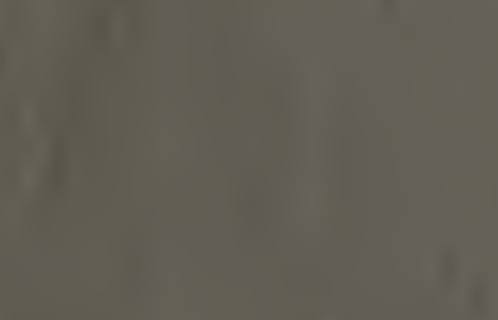

14.

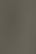

if

it<smiles>[C]1C=CC=C1</smiles>

\section{I}

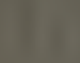

I

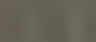

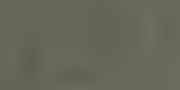


UNIVEABSTY OF HLINOIS-UABANA

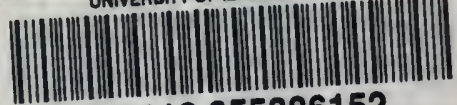
30112055386152 